\author{
JULIANA DURIGAN BAIA
}

Desenvolvimento e validação de uma cartilha educativa sobre a doença periodontal em cães e gatos

São Paulo

2018 


\section{Desenvolvimento e validação de uma cartilha educativa sobre a doença periodontal em cães e gatos}

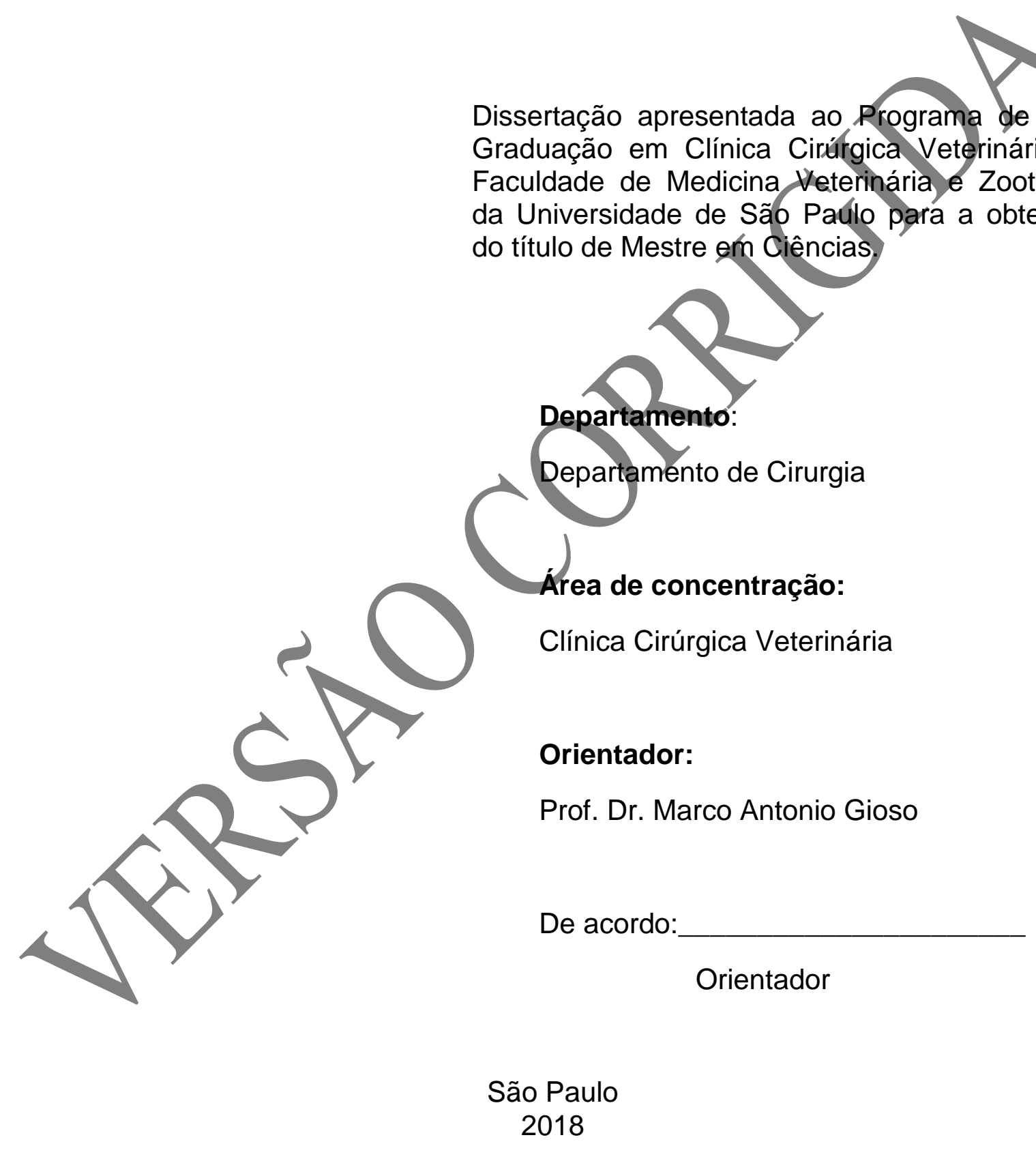

Obs.: A versão original encontra-se disponível na Biblioteca da FMVZ/USP. 
Autorizo a reprodução parcial ou total desta obra, para fins acadêmicos, desde que citada a fonte.

\section{DADOS INTERNACIONAIS DE CATALOGAÇÃO NA PUBLICAÇÃO}

(Biblioteca Virginie Buff D’Ápice da Faculdade de Medicina Veterinária e Zootecnia da Universidade de São Paulo)

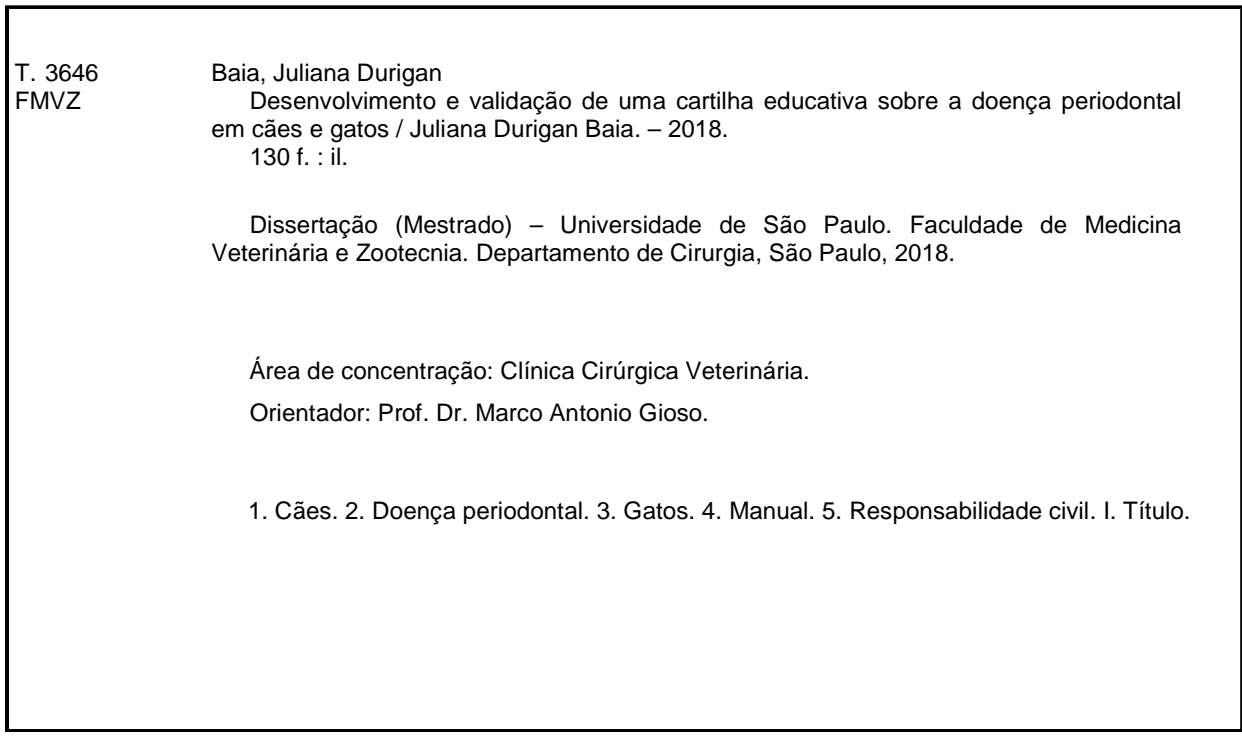

Ficha catalográfica elaborada pela bibliotecária Maria Aparecida Laet, CRB 5673-8, da FMVZ/USP. 


\section{CERTIFIED}

We certify that the Research "Development and validation of an educational booklet about the periodontal disease in dogs and cats", protocol number CEUAx 1189290116, under the responsibility Marco Antonio Gioso, agree with Ethical Principles in Animal Research adopted by Ethic Committee in the Use of Animals of School of Veterinary Medicine and Animal Science (University of São Paulo), and was approved in the meeting of day April 14, 2016.

Certificamos que o protocolo do Projeto de Pesquisa intitulado "Desenvolvimento e validação de uma cartilha educativa sobre a doença periodontal em cães e gatos", protocolado sob o CEUAx n² 1189290116, sob a responsabilidade de Marco Antonio Gioso, está de acordo com os princípios éticos de experimentação animal da Comissão de Ética no Uso de Animais da Faculdade de Medicina Veterinária e Zootecnia da Universidade de São Paulo, e foi aprovado na reunião de 14 de abril de 2016.

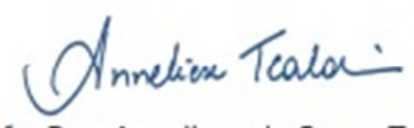

Profa. Dra. Anneliese de Souza Traldi Presidente da Comissão de Ética no Uso de Animais Faculdade de Medicina Veterinária e Zootecnia da Universidade de São Paulo

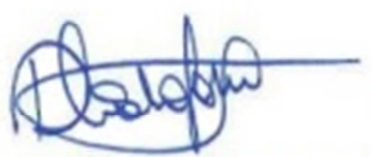

Profa. Dra. Claudia Madalena Cabrera Mori Vice-Presidente da Comissão de Ética no Uso de Animais Faculdade de Medicina Veterinária e Zootecnia da Universidade de São Paulo 


\section{FOLHA DE AVALIAÇÃO}

Autor: BAIA, Juliana Durigan

Título: Desenvolvimento e validação de uma cartilha educativa sobre a doença periodontal em cães e gatos

Dissertação apresentada ao Programa de Pós-Graduação em Clínica Cirúrgica Veterinária da Faculdade de Medicina Veterinária e Zootecnia da Universidade de São Paulo para obtenção do título de Mestre em Ciências

Data:

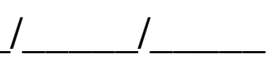

\section{Banca Examinadora}

Prof. Dr.

Instituição: Julgamento:

Prof. Dr.

Instituição: Julgamento:

Prof. Dr. Instituição: Julgamento: 


\section{AGRADECIMENTO}

Dizem que a sorte é o resultado do encontro entre preparo e oportunidade.

Que sorte a minha!

Fui muito bem preparada por meus pais, minhas irmãs e pela querida Professora Raquel de Souza Lemos, tendo o privilégio de receber do Professor Doutor Marco Antonio Gioso uma grande oportunidade.

Agradeço aos meus três mentores profissionais, Professores Doutores Daniel Giberne Ferro, Vanessa Graciela Gomes Carvalho e Viviam Nunes Pignone, pelo grande exemplo de ética, dedicação e amor à profissão.

Agradeço também aos colegas do Laboratório de Odontologia Comparada (LOC) da Faculdade de Medicina Veterinária e Zootecnia (FMVZ) da Universidade de São Paulo (USP) pelo aprendizado. Aos professores, pós-graduandos e funcionários da FMVZ USP, pelo apoio.

Agradeço à Coordenação de Aperfeiçoamento de Pessoal de Nível Superior (CAPES) que, com uma bolsa de estudos oferecida através da FMVZ USP, me permitiu a dedicação integral a esta pesquisa.

Agradeço aos incríveis amigos que tenho por todo o mundo e, mesmo separados por quilômetros ou oceanos, estiveram sempre presentes.

Ao Fernando Nucci Meyer e Leonardo Martins Napolitano, agradeço pelo inestimável apoio na elaboração gráfica deste projeto.

Agradeço ao Victor Hugo, minha companhia preferida.

A gratidão é a memória do coração!

Muito obrigada! 
"Aprender para viver com os outros homens com quem o mundo é compartilhado. Aprender para apropriar-se do mundo, de uma parte desse mundo, e para participar da construção de um mundo pré-existente. Aprender em uma história que é, ao mesmo tempo, profundamente minha, no que tem de única, mas que me escapa por toda a parte. Nascer, aprender, é entrar em um conjunto de relações e processos que constituem um sistema de sentido, onde se diz quem eu sou, quem é o mundo, quem são os outros." 


\section{RESUMO}

BAIA, JD. Desenvolvimento e validação de uma cartilha educativa sobre a doença periodontal em cães e gatos. [Development and validation of an educational booklet about the periodontal disease in dogs and cats]. 2018. $130 \mathrm{f}$. Dissertação (Mestrado em Ciências) - Faculdade de Medicina Veterinária e Zootecnia, Universidade de São Paulo, São Paulo, 2018.

Mesmo atingindo mais de $70 \%$ dos cães e gatos adultos, a doença periodontal tem seus efeitos locais e sistêmicos desconhecidos ou desconsiderados por muitos médicos veterinários. Isto ocorre devido à falta de informação sobre odontologia veterinária na grade curricular. Desta forma, estes profissionais instauram tratamentos incompletos ou incorretos para esta afecção, podendo gerar lesões iatrogênicas aos pacientes e tornando-se candidatos a processos éticos e civis. $\mathrm{Na}$ área da saúde, além do domínio técnico e ensino da ética, sugere-se a construção e distribuição de materiais educativos para orientação ao correto diagnóstico e tratamento de afecções, como forma de prevenir o erro médico. Sendo assim, no intuito de oferecer educação complementar, este estudo tem como objetivo a elaboração e validação de uma cartilha educativa em formato digital e livre distribuição, para despertar o interesse dos médicos veterinários a respeito da doença periodontal em cães e gatos. Esta cartilha destina-se aos médicos veterinários não especializados, porém atuantes em odontologia veterinária, a fim de reduzir, nesta afecção, a ocorrência de diagnósticos e tratamentos incompletos ou incorretos.

Palavras-chave: Cães. Doença periodontal. Gatos. Manual. Responsabilidade civil. 


\begin{abstract}
BAIA, JD. Development and validation of an educational booklet about the periodontal disease in dogs and cats. [Desenvolvimento e validação de uma cartilha educativa sobre a doença periodontal em cães e gatos]. 2018. $130 \mathrm{f}$. Dissertação (Mestrado em Ciências) - Faculdade de Medicina Veterinária e Zootecnia, Universidade de São Paulo, São Paulo, 2018.
\end{abstract}

Affecting more than $70 \%$ of adult cats and dogs, periodontal disease frequently has its local and systemic effects unknown or disregarded by veterinarians. This occurs due to lack of information about veterinary dentistry in college curriculum. Thus, these professionals choose incomplete or incorrect treatments to this condition, causing iatrogenic lesions to patients and becoming targets of ethical and civil lawsuits. In the healthcare sector, besides technical skills and teaching medical ethics, the construction and distribution of educational materials are suggested as an option to prevent medical errors from occurring. Therefore, in order to offer complementary education, this study aims to formulate and validate a digital educational booklet, with free distribution, as an attempt to make veterinarians interested about periodontal disease in dogs and cats. The intention of this material is to achieve veterinarians that work with veterinary dentistry even without being specialized, as an attempt to reduce the occurrence of incomplete or incorrect diagnosis and treatment of this condition.

Keywords: Booklet. Cats. Civil liability. Dogs. Periodontal disease. 


\section{LISTA DE FIGURAS}

Figura 1 - Representação didática do órgão dental hígido ..............................17

Figura 2 - Possíveis sinais clínicos da doença periodontal em cães e gatos ......21

Figura 3 - Cálculo dentário em cavidade oral de gato ........................................

Figura 4 - Retração gengival em cavidade oral de cão ………........................25

Figura 5 - Identificação de bolsa periodontal em cavidade oral de cão ...............26

Figura 6 - Mensuração de bolsa periodontal em cavidade oral de cão ................27

Figura 7 - Exposição de furca em cavidade oral de cão …………...................28

Figura 8 - Gengivite em cavidade oral de cão ……...........................................

Figura 9 - Aspecto radiográfico da periodontite inicial em cão .............................31

Figura 10 - Aspecto radiográfico da periodontite moderada em cão …….............32

Figura 11 - Aspecto radiográfico da periodontite avançada em gato ....................33

Figura 12 - Utilização de cureta odontológica em nível supragengival .................40

Figura 13 - Utilização de cureta odontológica em nível subgengival .......................41

Figura 14 - Utilização de ultrassom odontológico em nível supragengival ...........42

Figura 15 - Utilização de ultrassom odontológico em nível subgengival ...............43

Figura 16 - Polimento dentário em dente canino (304) de cão .............................44

Figura 17 - Elementos que determinam responsabilidade por culpa ...................47

Figura 18 - Escala de respostas .......................................................................61 


\section{LISTA DE GRÁFICOS}

Gráfico 1 - Dados referentes à idade dos participantes do estudo, obtidos a partir do questionário de avaliação da cartilha educativa.

Gráfico 2 - Dados referentes ao sexo dos participantes do estudo, obtidos a partir do questionário de avaliação da cartilha educativa

Gráfico 3 - Dados referentes aos esclarecimentos sobre os efeitos sistêmicos da doença periodontal em cães e gatos, obtidos a partir do questionário de avaliação da cartilha educativa

Gráfico 4 - Dados referentes aos esclarecimentos sobre os riscos das lesões iatrogênicas e possíveis consequências legais, obtidos a partir do questionário de avaliação da cartilha educativa 66

Gráfico 5 - Dados referentes à apresentação clara e objetiva das informações contidas no material, obtidos a partir do questionário de avaliação da cartilha educativa 67

Gráfico 6 - Dados referentes a opinião dos respondentes sobre o papel das cartilhas educativas utilizadas como ferramentas complementares ao ensino da doença periodontal em cães e gatos

Gráfico 7 - Dados referentes à opinião dos respondentes sobre o ensino da doença periodontal em cães e gatos na graduação de medicina veterinária. 69 


\section{LISTA DE TABELAS}

Tabela 1 - Dados referentes aos estados brasileiros de atuação profissional dos respondentes do questionário de avaliação da cartilha educativa 64

Tabela 2 - Nível de concordância das afirmações referentes ao conteúdo que compõe a cartilha educativa 65

Tabela 3 - Respostas referentes aos aspectos visuais do material, obtidos a partir do questionário de avaliação da cartilha educativa 68 


\section{SUMÁRIO}

INTRODUÇÃO 14

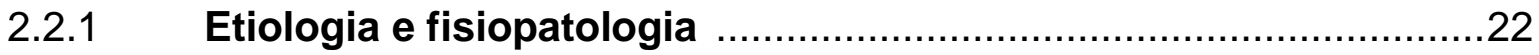

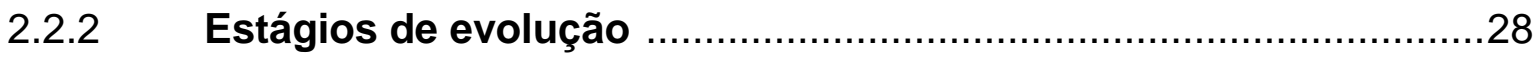

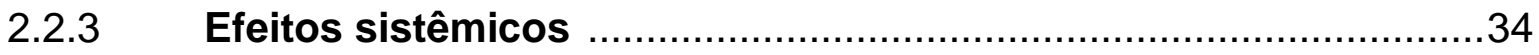

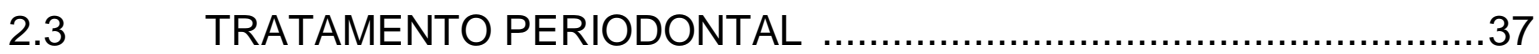

2.4 RESPONSABILIDADE CIVIL E ÉTICA DO MÉDICO VETERINÁRIO .45

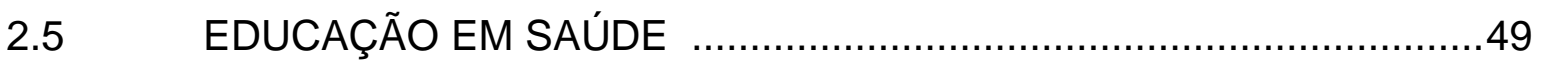

2.5.1 Processo ensino-aprendizagem …..........................................

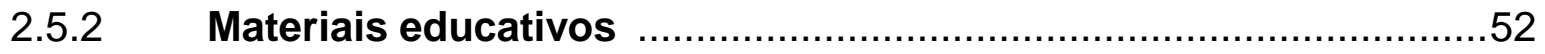

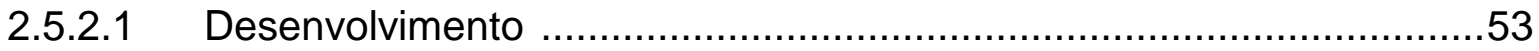

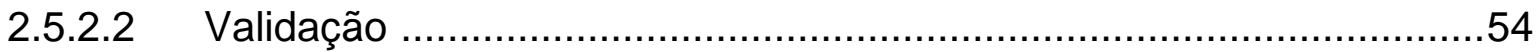

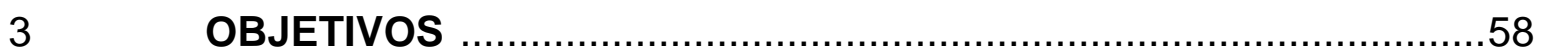

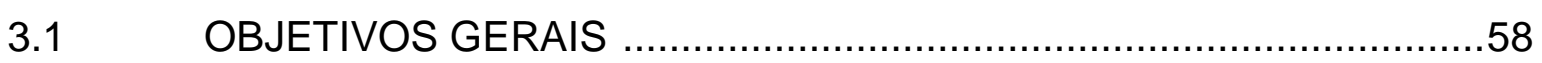

3.2 OBJETIVOS ESPECÍFICOS …...................................................

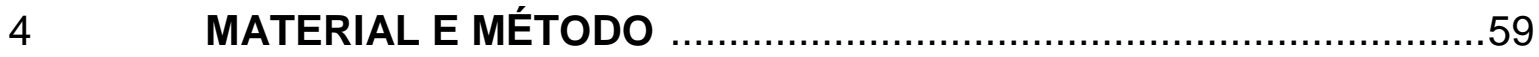

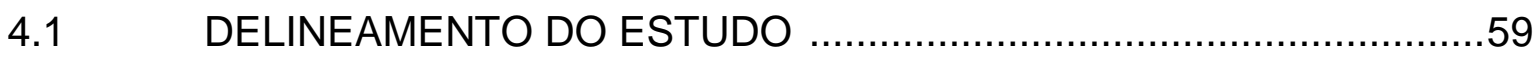

$4.2 \quad$ PROCESSO DE ELABORAÇÃO DA CARTILHA ..............................59

$4.3 \quad$ PROCESSO DE VALIDAÇÃO DA CARTILHA ………......................

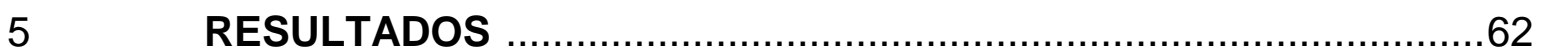

5.1 RESULTADOS OBTIDOS PELO QUESTIONÁRIO ...........................62

5.1.1 Características dos avaliadores …................................................62

5.1.2 Avaliação do conteúdo da cartilha educativa .................................64

5.1.3 Avaliação dos aspectos visuais e considerações finais ...............67

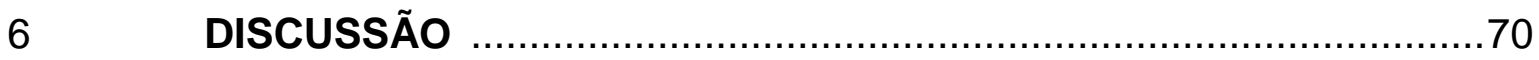

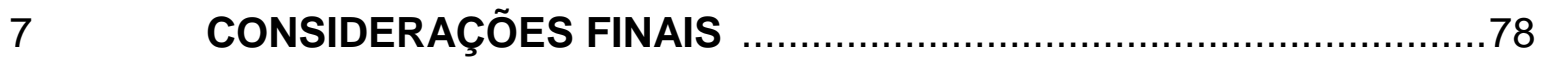

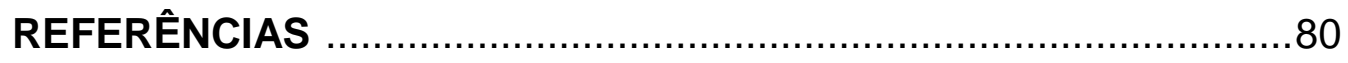

APÊNDICE A - INSTRUMENTO DE AVALIAÇÃO ……...................96

APÊNDICE B - CARTILHA EDUCATIVA..........................................102 


\section{INTRODUÇÃO}

A importância do correto diagnóstico e tratamento da doença periodontal em cães e gatos ainda é pouco discutida entre a maioria dos médicos veterinários, tornando-se origem comum de erro médico na profissão. Diversos são os relatos de profissionais que identificam a doença periodontal apenas como halitose e acúmulo de cálculo dental em seus pacientes, instaurando como tratamento incompleto apenas a raspagem de cálculo e placa bacteriana em nível supragengival, comprometendo a saúde animal (GORREL, 2010; LOBPRISE, 2010).

No incorreto tratamento da doença periodontal de cães e gatos, relata-se a ocorrência de diversas ações iatrogênicas em tecido mole, ósseo e pulpar, como lesões térmicas, lacerações, fraturas, inflamações e infecções, problemas dermatológicos, respiratórios, oftálmicos e até cerebrais (DUKE et al., 2014; GORREL, 2010; REITER; BRADY; HARVEY, 2004; STILES et al., 2012; TROXEL, 2015). De acordo com o Código de Ética do Médico Veterinário, devem ser responsabilizados no âmbito ético e civil, todos os profissionais responsáveis por lesões iatrogênicas em seus pacientes (CFMV, 2016).

Por serem comuns estas práticas, existem diversas discussões a respeito da importância do ensino da ética na área da saúde, no intuito de tentar reduzir a frequência de lesões iatrogênicas (MAGALHÃES-SANT'ANA, 2016; PELLEGRINO; MCELHINNEY, 1982; BOUFORD; CARSON, 1984; BICKEL, 1987). Ao oferecer regras de conduta, a ética busca fornecer um ponto fixo de referência em uma sociedade que se transforma constantemente. Assim, a partir da ética, o profissional entende o que é certo e esperado dele (MAGALHÃES-SANT'ANA, 2016). Logo, o domínio técnico e o ensino da ética são identificados como as principais estratégias na prevenção ao erro médico (BITENCOURT et al., 2007; MAGALHÃES-SANT'ANA, 2016; SULMASY, 2000).

Neste sentido, cartilhas e manuais educativos são formatos comuns de educação complementar utilizados na comunicação em saúde, pois demonstram habilidades técnicas e estimulam comportamentos, influenciam percepções e normas sociais, visando o desenvolvimento do pensamento crítico e reflexivo do profissional, no intuito de gerar melhoria na saúde por propor soluções aos 
problemas identificados (MACHADO et al., 2007; MOREIRA; NÓBREGA; SILVA, 2003).

Este estudo busca trazer como reflexão à importância da doença periodontal para a saúde oral e sistêmica dos cães e gatos, além das consequências negativas a partir da escolha do profissional em não tratar ou tratar inadequadamente esta doença em seus pacientes. Para isto, foi elaborada uma cartilha educativa sobre a doença periodontal em cães e gatos, para ser utilizada como ferramenta complementar de educação aos médicos veterinários. 


\section{REVISÃO DE LITERATURA}

\subsection{ANATOMIA DO DENTE E PERIODONTO}

Os dentes são estruturas encontradas na cavidade oral, nos alvéolos dos ossos da mandíbula e maxila. Cães e gatos são caracterizados como heterodontes, ou seja, não possuem todos os dentes com o mesmo formato e tipo (WIGGS; LOBPRISE, 1997). A anatomia dos dentes de um cão diferencia-se do gato em diversos aspectos. Os gatos possuem normalmente trinta dentes permanentes, sendo que a dentição decídua, conhecida popularmente como dentição de leite, consiste em vinte e seis elementos dentários. Nos cães, são vinte e oito dentes decíduos e quarenta e dois permanentes. Ambos possuem dentes do tipo incisivo, canino, pré-molar e molar, em quantidades diferentes, porém com comum função: tanto em gatos como em cães, os incisivos são usados para preensão e corte, os caninos atuam como ferramenta de dilaceração e os pré-molares e molares realizam a trituração (MADEIRA, 2006; TUTT, 2006).

O dente (Figura 1) é didaticamente dividido em três regiões: coroa, colo e raiz. Considera-se coroa a porção do dente hígido que não está recoberta pela gengiva, ou seja, a porção do dente que se encontra exposta e é visível. Por sua vez, a raiz é a porção revestida pela gengiva, dentro do alvéolo dentário e recoberta pelo cemento. O dente pode ter entre uma a três raízes, dependendo de sua localização anatômica, sendo chamado de unirradicular, birradicular ou trirradicular. Define-se colo como a região em que há a união entre a coroa e raiz (GORREL, 2010; WIGGS; LOBPRISE, 1997). 
Figura 1 - Representação didática do órgão dental hígido

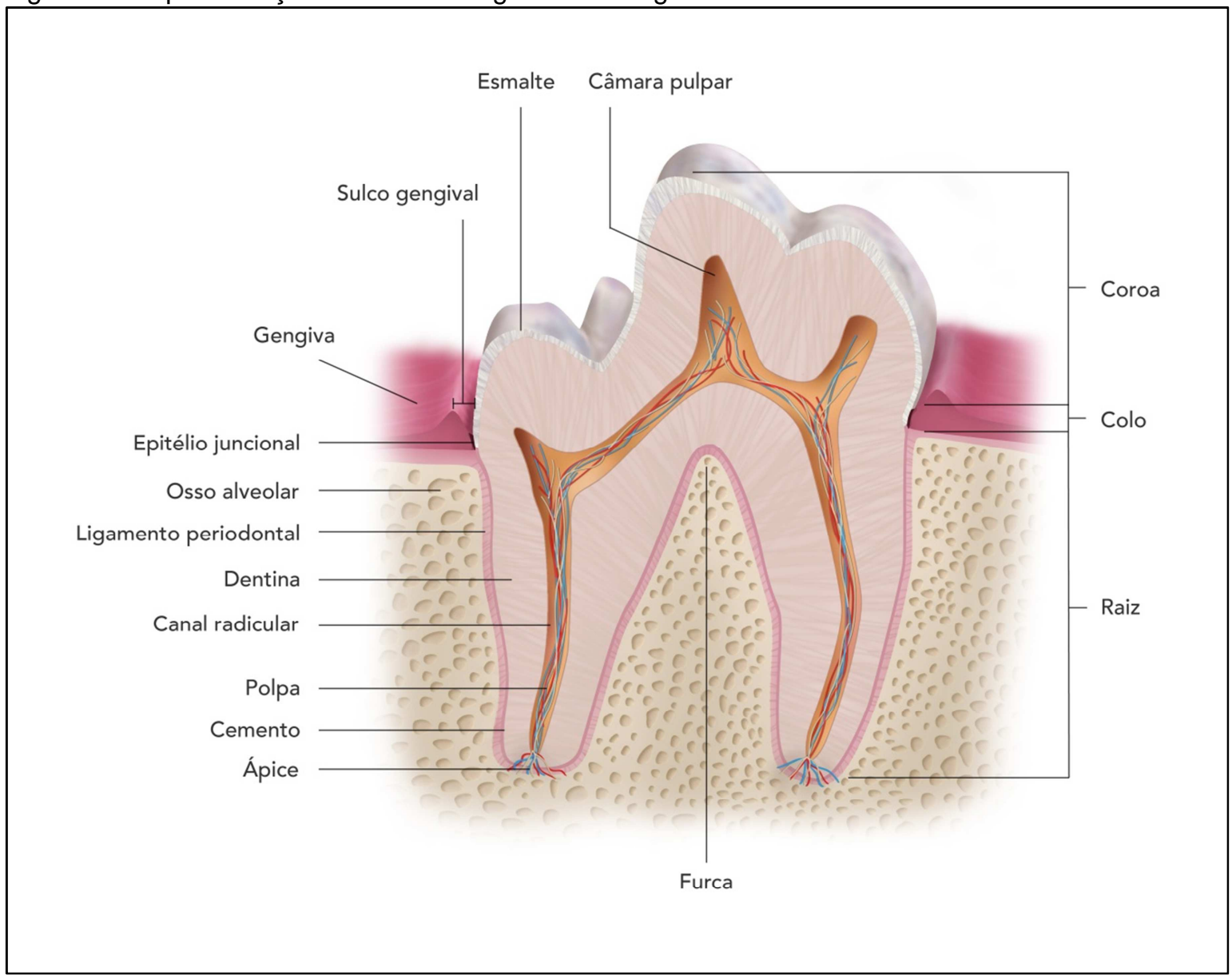

Fonte: (BAIA, 2018).

Legenda: Este desenho representa didaticamente o primeiro molar inferior de um cão adulto. Nota-se que o osso alveolar dá suporte e fornece o arcabouço para a fixação da raiz dentária. Isto ocorre através da ligação entre osso alveolar e cemento, pelas fibras do ligamento periodontal.

O esmalte, que envolve a coroa, é a estrutura mais dura e mineralizada do organismo. No cão e no gato, o esmalte é mais fino quando comparado ao esmalte do homem, não havendo, em nenhum deles, capacidade regenerativa ou reparadora (WIGGS; LOBPRISE, 1997).

O cemento é caracterizado como uma estrutura de tecido conjuntivo calcificado que reveste a raiz. Nele não há vascularização, porém há capacidade de reparação e reabsorção. Considera-se esta estrutura como um tecido de grande importância para a reparação das superfícies radiculares, manutenção dos espaços periodontais e das fibras do ligamento periodontal (LINDHE; LANG; KARRING, 2010). 
A dentina, considerada o principal componente de um dente adulto, é uma estrutura mineralizada e porosa, recoberta pelo cemento na porção radicular e pelo esmalte na porção coronal. Há duas categorias principais de dentina: a primária e a secundária. A dentina primária é formada antes do fechamento do ápice dentário e a secundária forma-se após este fechamento. Existe também a dentina chamada reparadora, ou dentina terciária, produzida em resposta a fatores irritantes como cárie e trauma oclusal (GORREL, 2010; HARGREAVES; BERMAN, 2017; LINDHE; LANG; KARRING, 2010).

No interior dos dentes encontra-se uma mesma estrutura denominada câmara pulpar na região de coroa e canal radicular na região de raiz, onde está inserida a polpa dentária. A polpa é composta por tecido conjuntivo frouxo, células mesenquimais indiferenciadas, vasos sanguíneos e linfáticos, feixes nervosos mielínicos e amielínicos, que mantém a vitalidade fisiológica e biológica do dente. $\mathrm{Na}$ sua periferia, encontra-se uma camada de células denominadas de odontoblastos, cuja função principal é produzir dentina (HARGREAVES; BERMAN, 2017; NIEMIEC, 2014; YASUI et al., 2017).

A gengiva é a camada mucosa que reveste o osso e atua em favor do hospedeiro contra danos mecânicos e microbianos. Divide-se em gengiva livre e aderida, sendo a primeira importante por possuir o sulco gengival entre ela e os dentes. O sulco gengival é um espaço fisiológico por onde são liberadas substâncias que atuam na proteção do tecido periodontal. A gengiva está fixada ao dente através do epitélio juncional, ou seja, é ele quem promove o contato entre a gengiva e o dente. Quando hígido, o epitélio juncional é comumente encontrado aderido apenas ao esmalte. Este pode, porém, encontrar-se aderido à junção amelocementária ou, em alguns casos, à raiz dentária (CARRANZA et al., 2012; LINDHE; LANG; KARRING, 2010). O epitélio juncional é responsável por contribuir para a prevenção da doença periodontal, pois forma uma barreira epitelial contra bactérias, permite 0 acesso de componentes do sistema imunológico do hospedeiro e consegue renovarse rapidamente (CARRANZA et al., 2012).

O osso alveolar é uma projeção dos ossos da mandíbula e maxila que envolve os dentes. Apresenta suprimento sanguíneo, sistema linfático e nervos, sendo a sua função principal absorver e distribuir a energia gerada pelos impactos da mastigação dentária. Junto a ele está o ligamento periodontal, constituído por tecido conjuntivo frouxo, celular e vascularizado, presente ao redor das raízes 
dentárias, responsável pela união do osso alveolar ao elemento dentário (LINDHE; LANG; KARRING, 2010).

O periodonto é definido como o conjunto das seguintes estruturas: cemento, gengiva, ligamento periodontal e osso alveolar. Tais estruturas têm como funções a proteção e o suporte do dente. Considera-se periodonto de sustentação o cemento, o ligamento periodontal e o osso alveolar. Já a gengiva é classificada como periodonto de proteção (CARRANZA et al., 2012; LINDHE; LANG; KARRING, 2010). 


\subsection{DOENÇA PERIODONTAL}

$\mathrm{Na}$ odontologia, o termo "doença periodontal" é utilizado para representar um grupo de afecções que acometem as estruturas de composição do periodonto (NOVAK, 2002). Sendo este termo também utilizado na medicina veterinária (AVDC, 2018c), a doença periodontal o conjunto de afecções mais comuns, encontrado em cães e gatos adultos (REICHART et al., 1984), apresentando prevalência maior que $70 \%$ (WIGGS; LOBPRISE, 1997). Ocorre em resposta à infecção originada da placa bacteriana no espaço subgengival, predominantemente do tipo anaeróbia e gramnegativa. Suas principais manifestações clínicas (Figura 2) incluem inflamação gengival, destruição do tecido periodontal de sustentação e reabsorção do osso alveolar (CARRANZA et al., 2012; LINDHE; LANG; KARRING, 2010). 
Figura 2 - Possíveis sinais clínicos da doença periodontal em cães e gatos

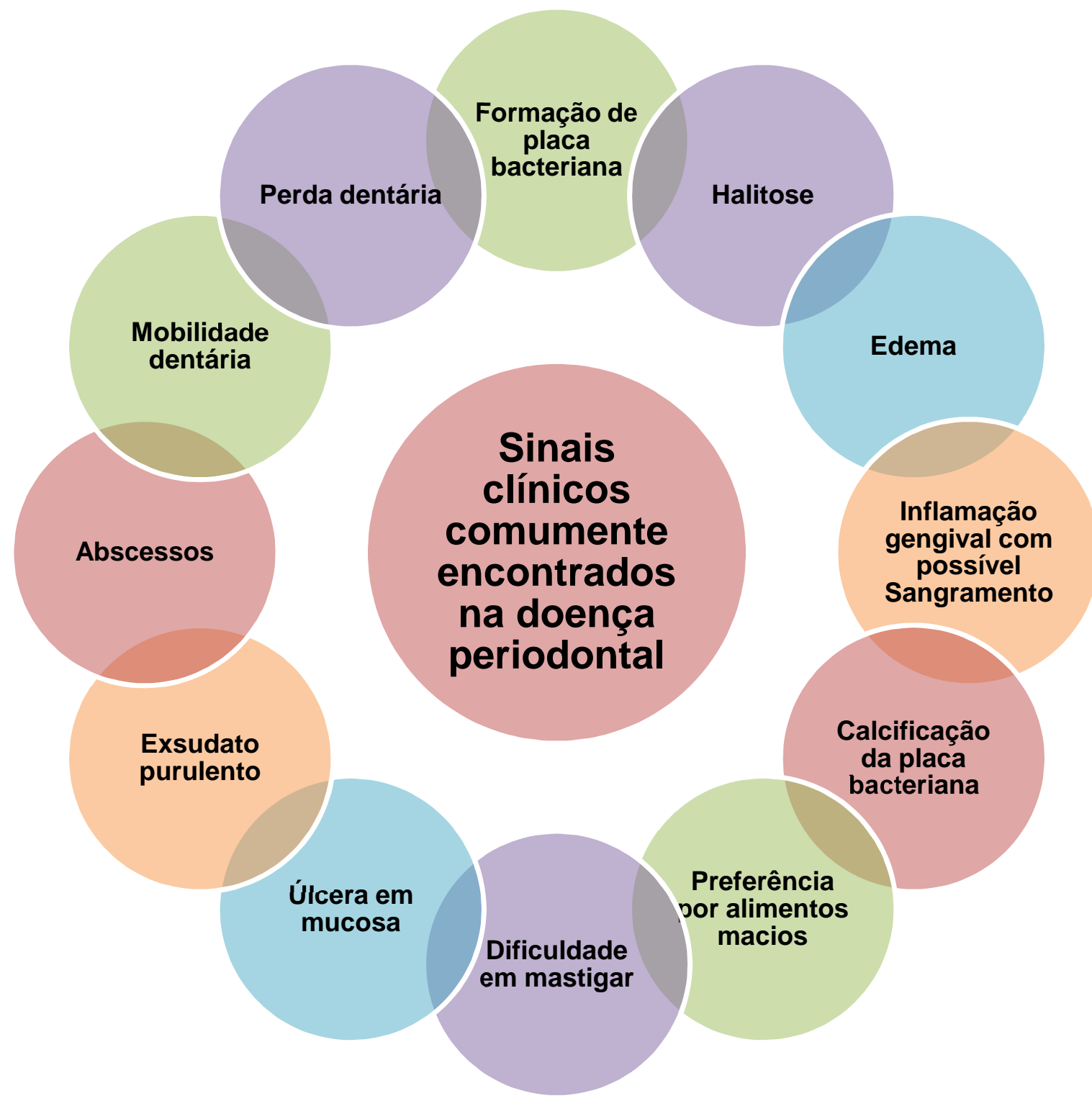

Fonte: (BAIA, 2018). 


\subsubsection{Etiologia e fisiopatologia}

A colonização bacteriana da cavidade oral tem início no momento do nascimento, sendo esta microbiota comensal capaz de aderir-se aos dentes imediatamente após limpeza dentária. Presente na superfície dentária desde sua erupção, a película aderida é uma camada de tecido orgânico, constituída por peptídeos, proteínas e glicoproteínas que revestem todas as superfícies da cavidade oral, contendo moléculas que servem como sítios de adesão inicial e fixação bacteriana (CARRANZA et al., 2012).

Para que a colonização bacteriana ocorra na película, faz-se necessário o transporte de bactérias até a superfície dental. Isto se dá a partir de fenômenos como a sedimentação de microrganismos, o fluxo líquido, a atividade quimiotática e o movimento browniano - que permite o deslocamento de partículas suspensas em um meio aquoso. Em seguida, a adesão reversível das bactérias ocorre pelas forças de van der Waals e forças repulsivas eletrostáticas, dois importantes processos de interação físico-química. Após a fraca ligação inicial, uma forte ligação é estabelecida entre bactéria e superfície, sendo que a rugosidade desta protege as bactérias contras forças de cisalhamento, facilitando a mudança da ligação reversível para a irreversível (CARRANZA et al., 2012).

As primeiras colônias bacterianas aderidas à superfície agem como receptores para a adesão das demais bactérias, mecanismo conhecido por coadesão. Este mecanismo é responsável pela colonização e maturação da placa bacteriana. Nela, as bactérias interagem beneficamente entre si e tornam-se quase mil vezes mais resistentes aos antimicrobianos (CARRANZA et al., 2012; PETERS et at., 2012).

A placa bacteriana dentária, agente etiológico primário da doença periodontal, é uma substância estruturada e resiliente, de coloração amareloacinzentada, capaz de aderir-se firmemente às superfícies duras intraorais. Ela é composta, inicialmente, por células microbianas encaixadas em uma matriz de substâncias poliméricas extracelulares, como polissacarídeos, glicoproteínas, proteínas, cálcio, fósforo, sódio, potássio e flúor (CARRANZA et al., 2012). Classifica-se como supragengival ou subgengival, de acordo com o local que se insere. A placa supragengival apresenta-se na margem e acima da gengiva. Já a 
placa subgengival encontra-se abaixo da margem gengival, entre dente e epitélio do sulco gengival (CARRANZA et al., 2012).

$\mathrm{Na}$ sua formação inicial supragengival, constitui-se predominantemente por bacilos e cocos não patogênicos, gram-positivos, aeróbios e sem motilidade. A composição da placa subgengival depende da profundidade do sulco gengival ou bolsa periodontal, apresentando, em sua maioria, microrganismos com potencial patogênico, gram-negativos e anaeróbios (CARRANZA et al., 2012).

A especificidade local da placa relaciona-se diretamente ao tipo de doença periodontal, além da resposta inflamatória regional gerada por sua maturação. A resposta inicial, gengivite, está relacionada com a placa supragengival. Este é um processo reversível que afeta o tecido mole, não havendo perda de nível clínico de inserção do epitélio juncional. Por sua vez, a periodontite, relacionada à placa subgengival, é a progressão da gengivite, de caráter irreversível, que envolve a destruição do osso alveolar, ligamento periodontal e cemento (CARRANZA et al., 2012).

Para que a placa bacteriana lesione os tecidos periodontais, dando início à doença periodontal, deve haver um contínuo acúmulo e organização de seus constituintes. Sendo assim, conforme ocorre acúmulo de placa, o sulco gengival torna-se ambiente propício a outras bactérias, como espiroquetas, bacilos e filamentos gram-negativos, anaeróbios facultativos e estritos, altamente patogênicos ao periodonto (CARRANZA et al., 2012; GORREL, 2010; PETERS et al., 2012). A persistência da placa bacteriana desencadeia respostas do sistema imunológico do hospedeiro, resultando no aumento da produção de prostaglandinas, estimulação de osteoclastos e ativação de proteases e colagenases, fatores estes que levam à reabsorção óssea e retração gengival (CARRANZA et al., 2012; LILJESTRAND et al., 2018).

A partir da placa supragengival e com o favorecimento do $\mathrm{pH}$ alcalino, o cálculo dentário (Figura 3) forma-se através de sais minerais provenientes da saliva, que precipitam e formam um material duro, mineralizado e rugoso, atuando como facilitador para o acúmulo de mais placa. Esta estrutura potencializa os efeitos patogênicos da placa bacteriana (CARRANZA et al., 2012; KOUKI et al., 2013; TROMP et al., 2017). 
Figura 3 - Cálculo dentário em cavidade oral de gato

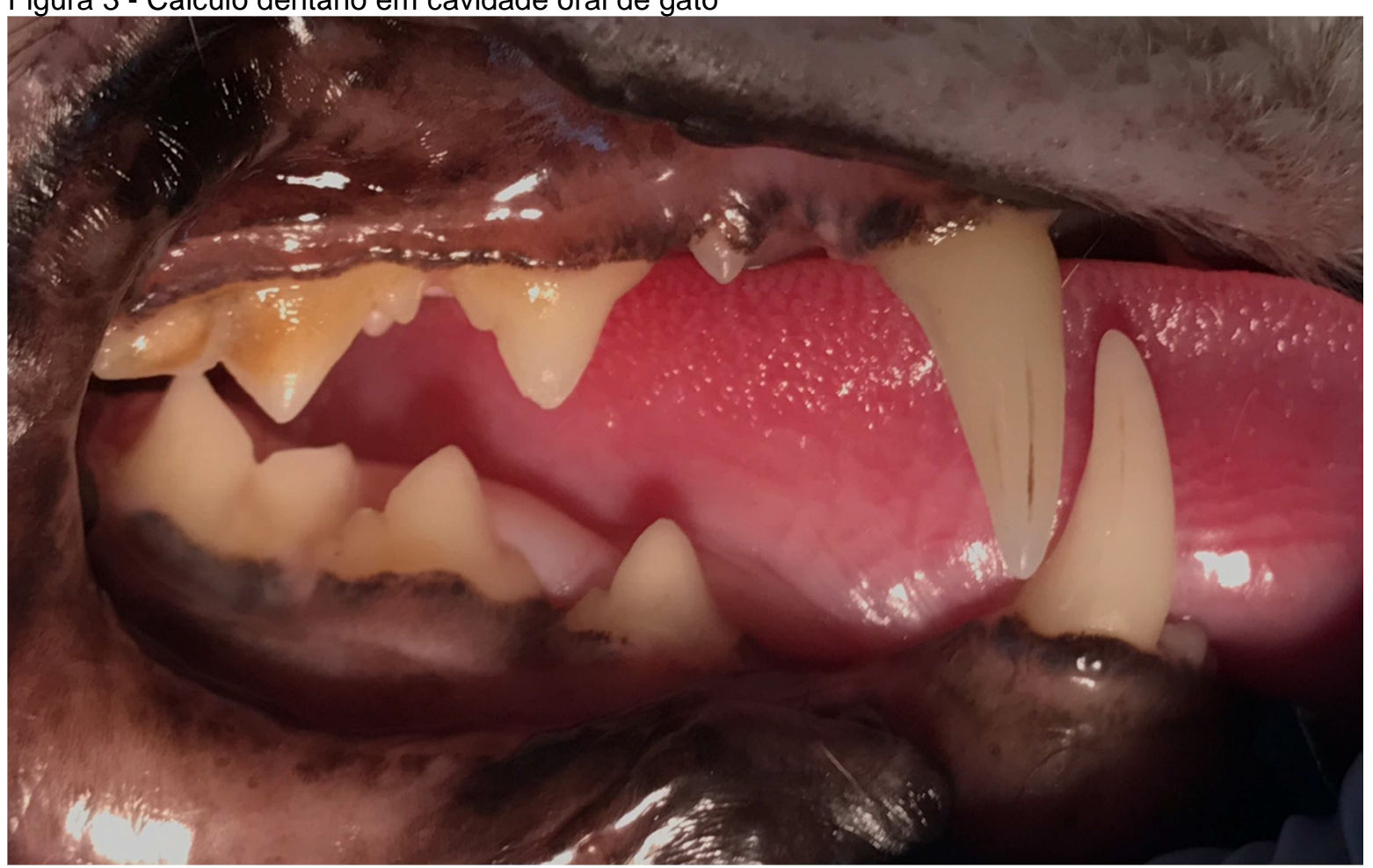

Fonte: (BAIA, 2018).

Legenda: Lado direito da cavidade oral de paciente felino diagnosticado com periodontite inicial. Pela imagem, nota-se maior acúmulo de cálculo dentário em dente primeiro molar superior (109), além de tumefação gengival caracterizando gengivite.

Além da placa bacteriana, consideram-se diversos fatores contribuintes à suscetibilidade e progressão desta afecção, como a microbiota oral, o cálculo dentário, fatores genéticos, saúde geral do paciente, idade, higiene oral e hábitos mastigatórios. Irritantes locais, como por exemplo, o trauma oclusal e corpos estranhos também têm efeito sobre o desenvolvimento da doença periodontal (GORREL, 2010; WIGGS; LOBPRISE, 1997).

De acordo com Gioso et al. (2001), a raça atua como fator contribuinte ao desenvolvimento e progressão desta afecção. Animais de menor porte apresentam desproporção entre o tamanho de seus dentes e mandíbulas, quando comparados aos de maior porte. Sendo assim, nestes pacientes há uma redução do espaço entre os elementos dentários, com consequente aumento na dificuldade de higienização e maior probabilidade de proliferação bacteriana patogênica local.

Com a progressão do contínuo estímulo inflamatório a partir da placa instalada, ocorrem alterações degenerativas no epitélio juncional que levam à migração deste, dando origem a diversas características clínicas (CARRANZA et al., 
2012; TROMP et al., 2017). Devido a importância da integridade do epitélio juncional para a preservação da doença periodontal, faz-se necessário compreender alguns critérios de caracterização clínica referentes à sua migração, como retração gengival (Figura 4), bolsa periodontal (Figuras 5 e 6) e exposição de furca (Figura 7) (GORREL, 2010).

A retração gengival é uma característica importante da migração do epitélio juncional, pois torna exposta a região radicular do dente acometido.

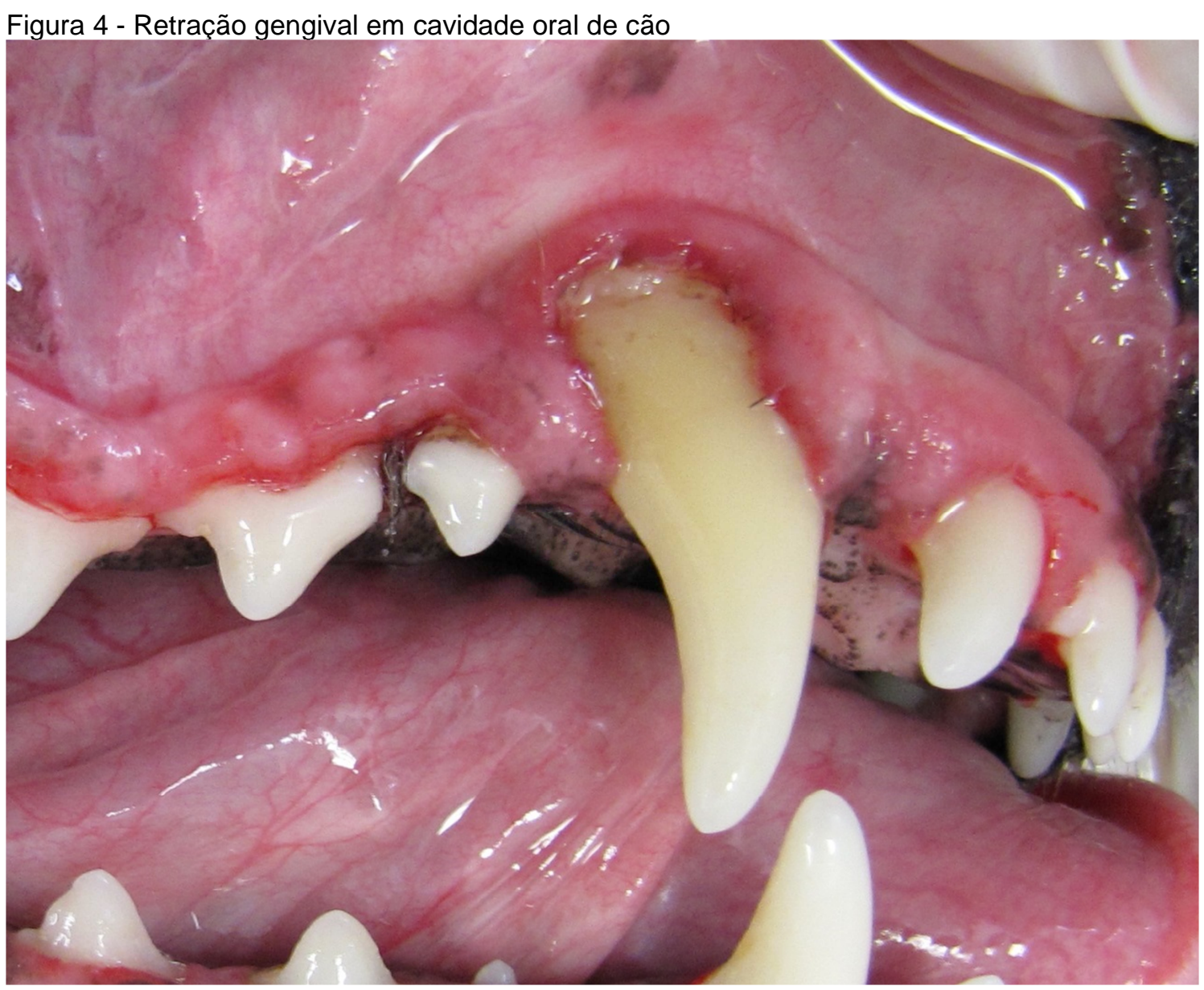

Fonte: (BAIA, 2018).

Legenda: Lado superior direito de paciente canino apresentando retração gengival em dente canino (104), primeiro pré-molar superior (105) e raiz mesial do segundo pré-molar superior (106). 
Fisiologicamente, o sulco gengival apresenta profundidade média de até 1 $\mathrm{mm}$ no gato e até $3 \mathrm{~mm}$ no cão. Além desta média, a profundidade resultante da sondagem periodontal determina migração do epitélio juncional, destruição do ligamento periodontal e reabsorção do osso alveolar (GORREL, 2010). Logo, a bolsa periodontal define-se clinicamente como um sulco gengival patologicamente aprofundado, sendo uma característica importante desta doença (CARRANZA et al., 2012; TROMP et al., 2017).

Figura 5 - Identificação de bolsa periodontal em cavidade oral de cão

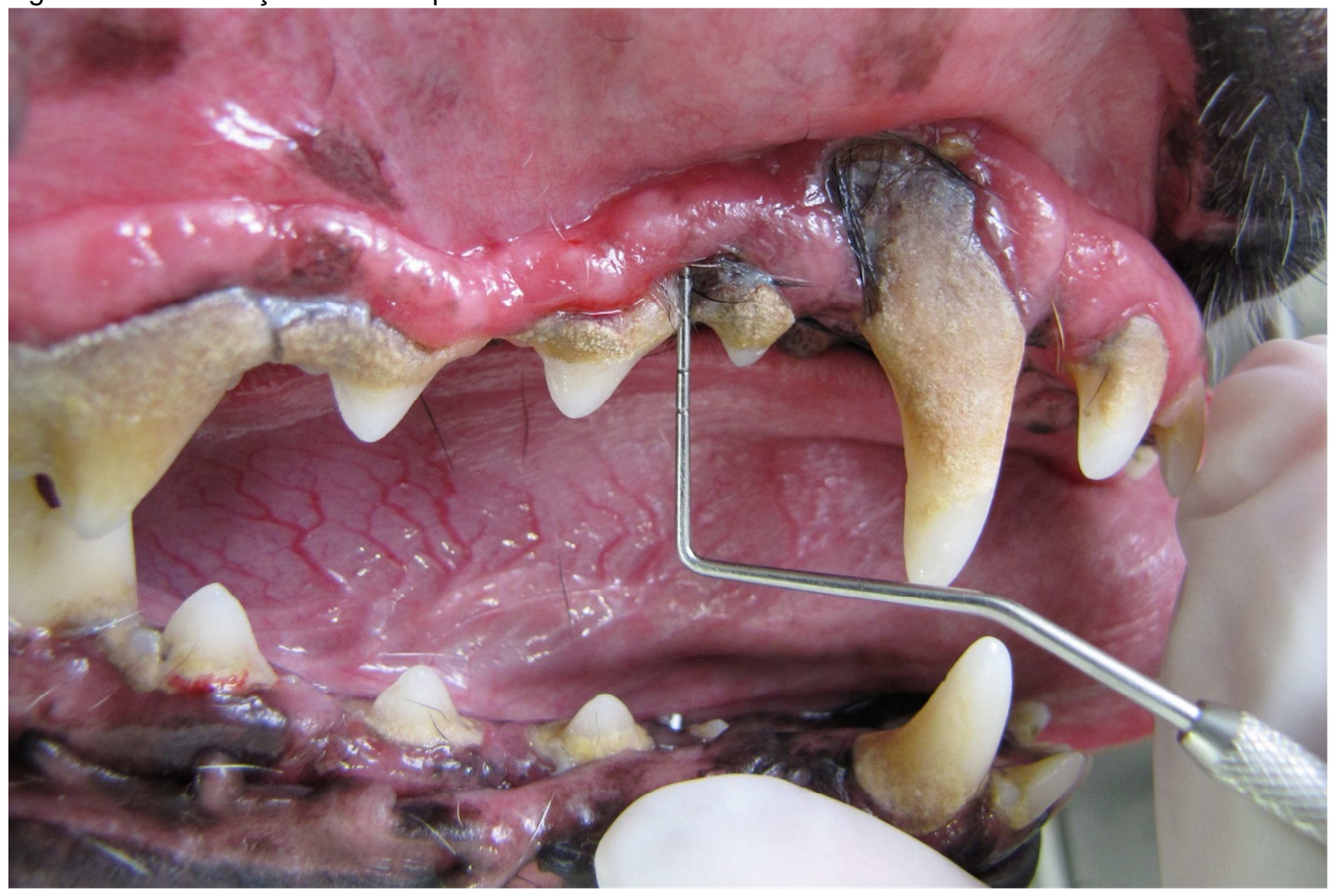

Fonte: (BAIA, 2018).

Legenda: Presença de bolsa periodontal de $5 \mathrm{~mm}$ em região de raiz mesial do segundo pré-molar superior direito (106) de cão. 
Figura 6 - Mensuração de bolsa periodontal em cavidade oral de cão

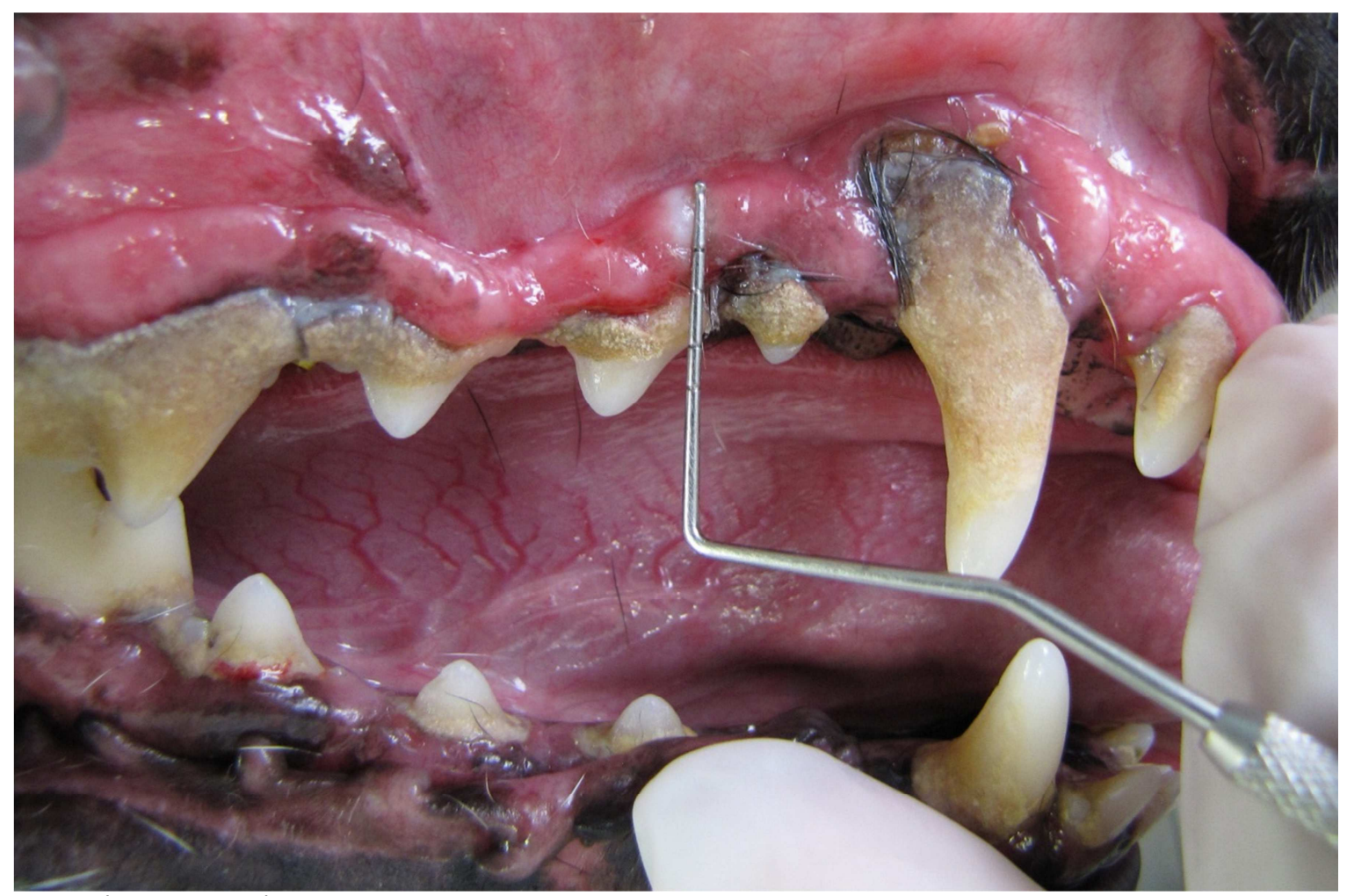

Fonte: (BAIA, 2018).

Legenda: Representação externa da sonda periodontal indicando a profundidade da bolsa periodontal de $5 \mathrm{~mm}$ em região de raiz mesial do segundo pré-molar superior direito (106) de cão.

O periodonto hígido apresenta a preservação da região de furca. A partir da migração do epitélio juncional, dentes multirradiculares podem apresentar exposição desta região (GORREL, 2010). Ao posicionar a sonda periodontal na região de furca, de maneira transversal ao dente, identifica-se a exposição de furca em estágio 1 caso a sonda periodontal avance por menos da metade do espaço ósseo da furca de um dente multirradicular com perda de inserção clínica. O estágio 2 é identificado se a sonda periodontal avançar por mais da metade do espaço ósseo da furca de um dente multirradicular com perda de inserção clínica, sem atingir sua extremidade. Por fim, a exposição de furca estágio 3 ocorre quando a sonda periodontal estendese completamente no espaço ósseo da furca, atravessando-o de um lado da furca ao outro (AVDC, 2018b). 
Figura 7 - Exposição de furca em cavidade oral de cão

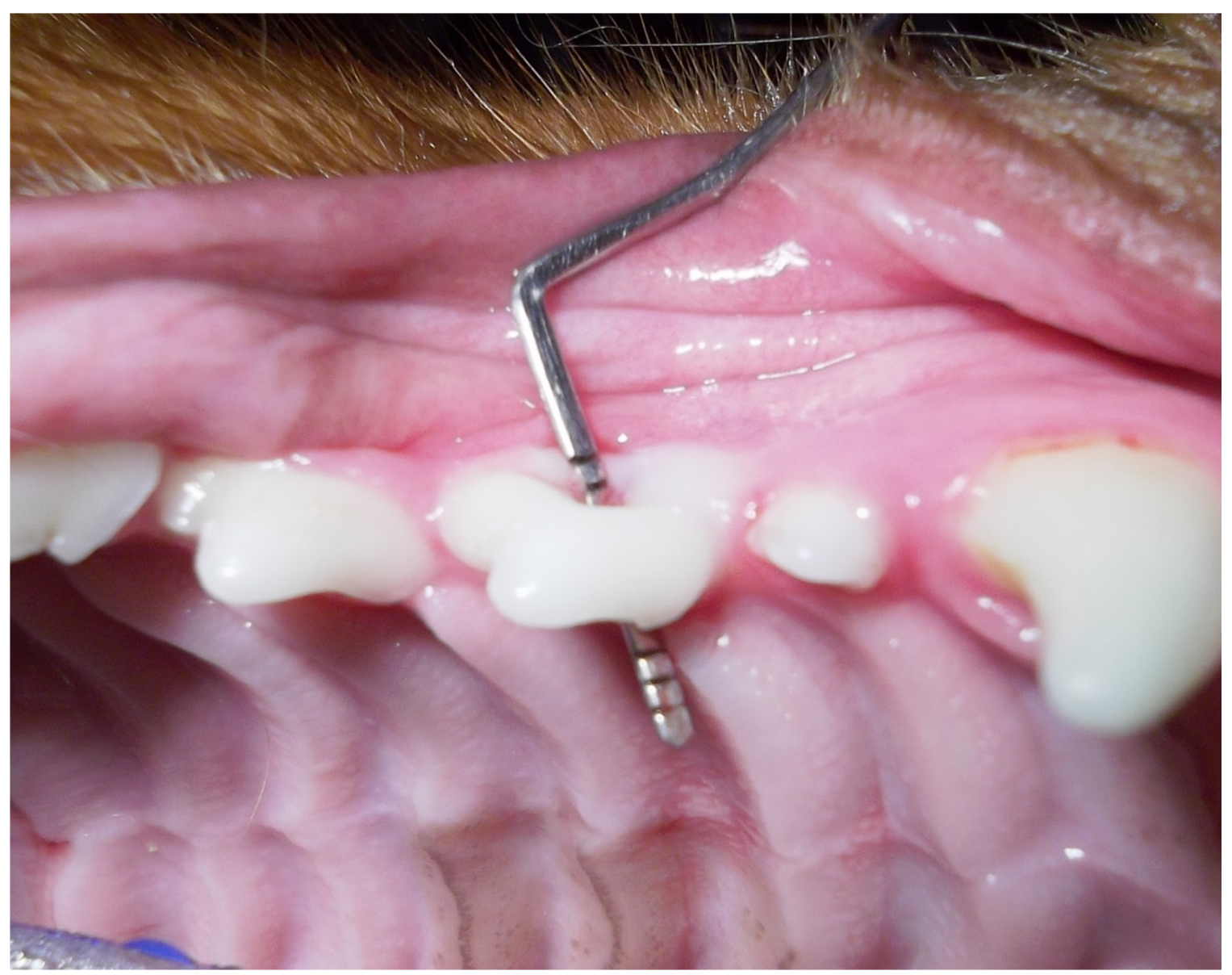

Fonte: (BAIA, 2018).

Legenda: Através da utilização da sonda periodontal, identifica-se clinicamente exposição de furca estágio 3 em dente segundo pré-molar superior direito (106) de paciente canino.

\subsubsection{Estágios de evolução}

Para facilitar estudos científicos a respeito das mais diversas afecções, incluindo doenças do periodonto, e auxiliar o profissional na organização de cuidados necessários relacionados à saúde de seus pacientes, o uso de sistemas para classificação de doenças é de suma importância. Na odontologia existem diversos autores que apresentam modelos de classificação das doenças periodontais (ARMITAGE, 1999).

No ano de 1999, a Academia Americana de Periodontia publicou a recomendação internacional para a classificação das doenças periodontais em seres humanos (ARMITAGE, 1999). Estas doenças foram categorizadas e classificadas de 
acordo com suas características clínicas, radiográficas e demográficas (KURGAN; KANTARCI, 2017).

O Colégio Americano de Odontologia Veterinária recomenda, com base no sistema de classificação de doença periodontal proposto por Wolf et al. (2005), que em animais, cada elemento dentário seja avaliado e classificado a partir de quatro diferentes estágios de evolução, de acordo com suas características clínicas e radiográficas (AVDC, 2018c).

O primeiro estágio caracteriza apenas gengivite (Figura 8), sem migração do epitélio juncional, mantendo preservada a margem óssea alveolar em sua altura e arquitetura. O segundo estágio caracteriza a periodontite inicial, com perda menor que $25 \%$ do nível clínico de inserção, ou, no máximo, exposição de furca estágio 1 no envolvimento de dentes multirradiculares. Neste estágio, há sinais radiográficos iniciais de periodontite. A perda clínica de inserção é menor que $25 \%$ quando mensurada com o uso clínico da sonda periodontal (Figura 9) ou determinação radiográfica da distância da margem alveolar até a junção amelocementária, relativa ao comprimento da raiz avaliada. O terceiro estágio, periodontite moderada, apresenta entre 25 e 50\% de perda clínica de inserção (Figura 10), mensurada a partir do uso clínico da sonda periodontal ou determinação radiográfica da distância da margem alveolar até a junção amelocementária, em relação ao comprimento da raiz avaliada, ou apresenta exposição de furca estágio $2 \mathrm{em}$ dentes multirradiculares. O quarto estágio, periodontite avançada, apresenta perda clínica de inserção maior que 50\% (Figura 11), mensurada a partir do uso clínico da sonda periodontal, determinação radiográfica da distância da margem alveolar até a junção amelocementária em relação ao comprimento da raiz avaliada, ou envolvimento de exposição de furca estágio 3 em dentes multirradiculares (AVDC, 2018c). 
Figura 8 - Gengivite em cavidade oral de cão

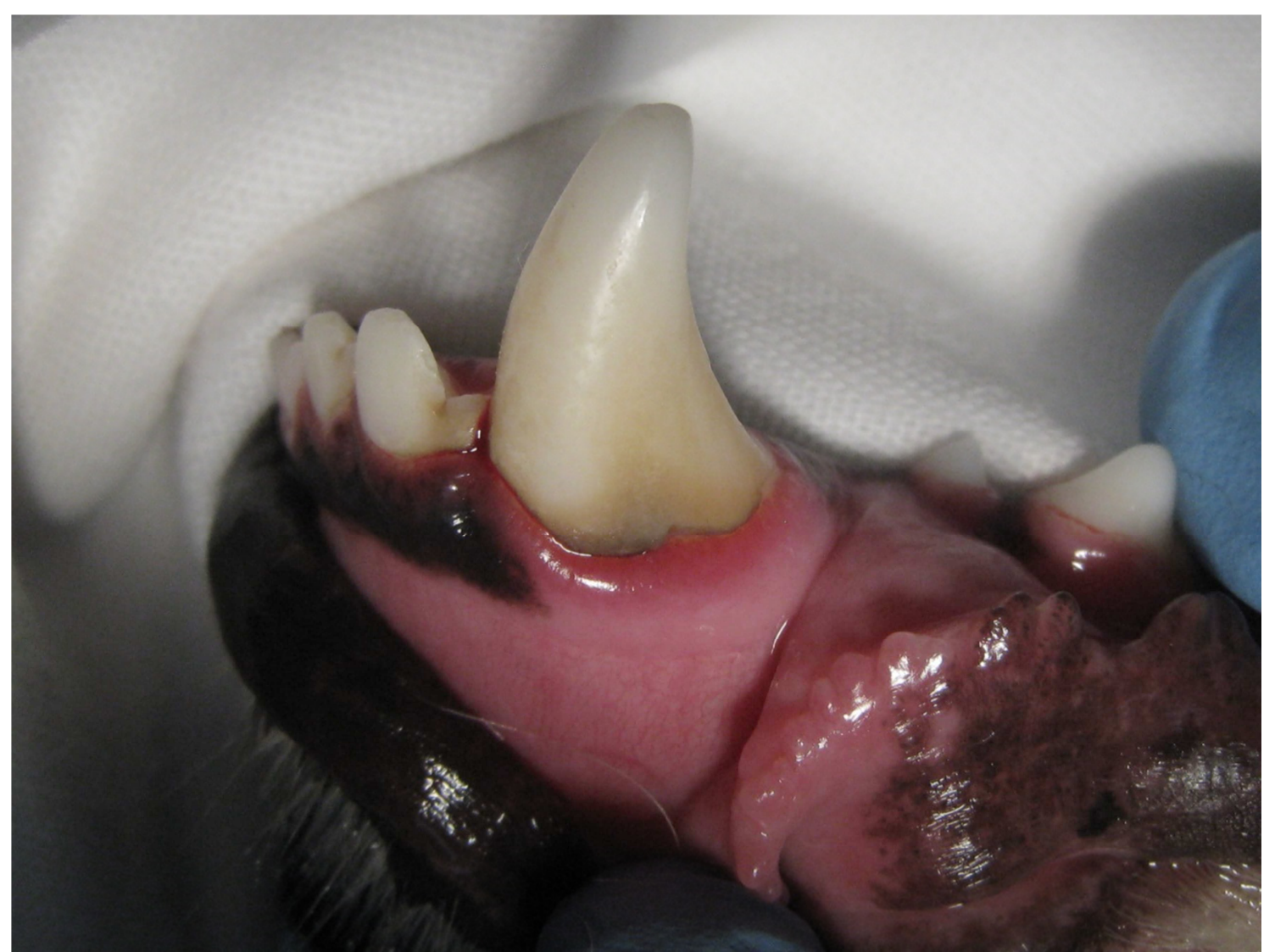

Fonte: (BAIA, 2018).

Legenda: Paciente canino diagnosticado com doença periodontal em estágio 1. Pode-se notar tumefação gengival e presença de inflamação localizada, principalmente, em região adjacente aos dentes. 
Figura 9 - Aspecto radiográfico da periodontite inicial em cão

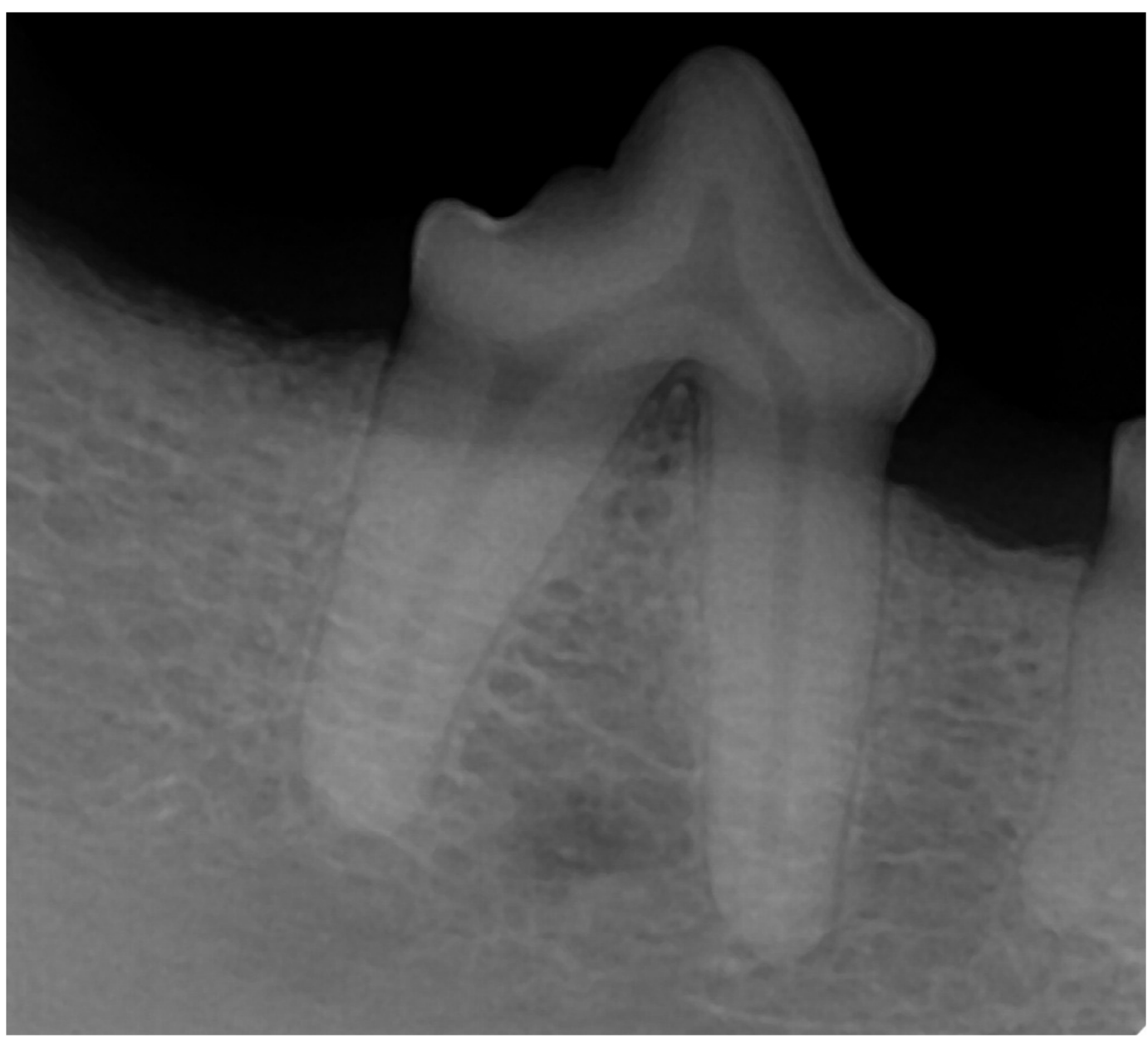

Fonte: (BAIA, 2018).

Legenda: Radiografia intraoral de dente terceiro pré-molar inferior direito (407) de cão com perda óssea menor que $25 \%$. 
Figura 10 - Aspecto radiográfico de periodontite moderada em cão

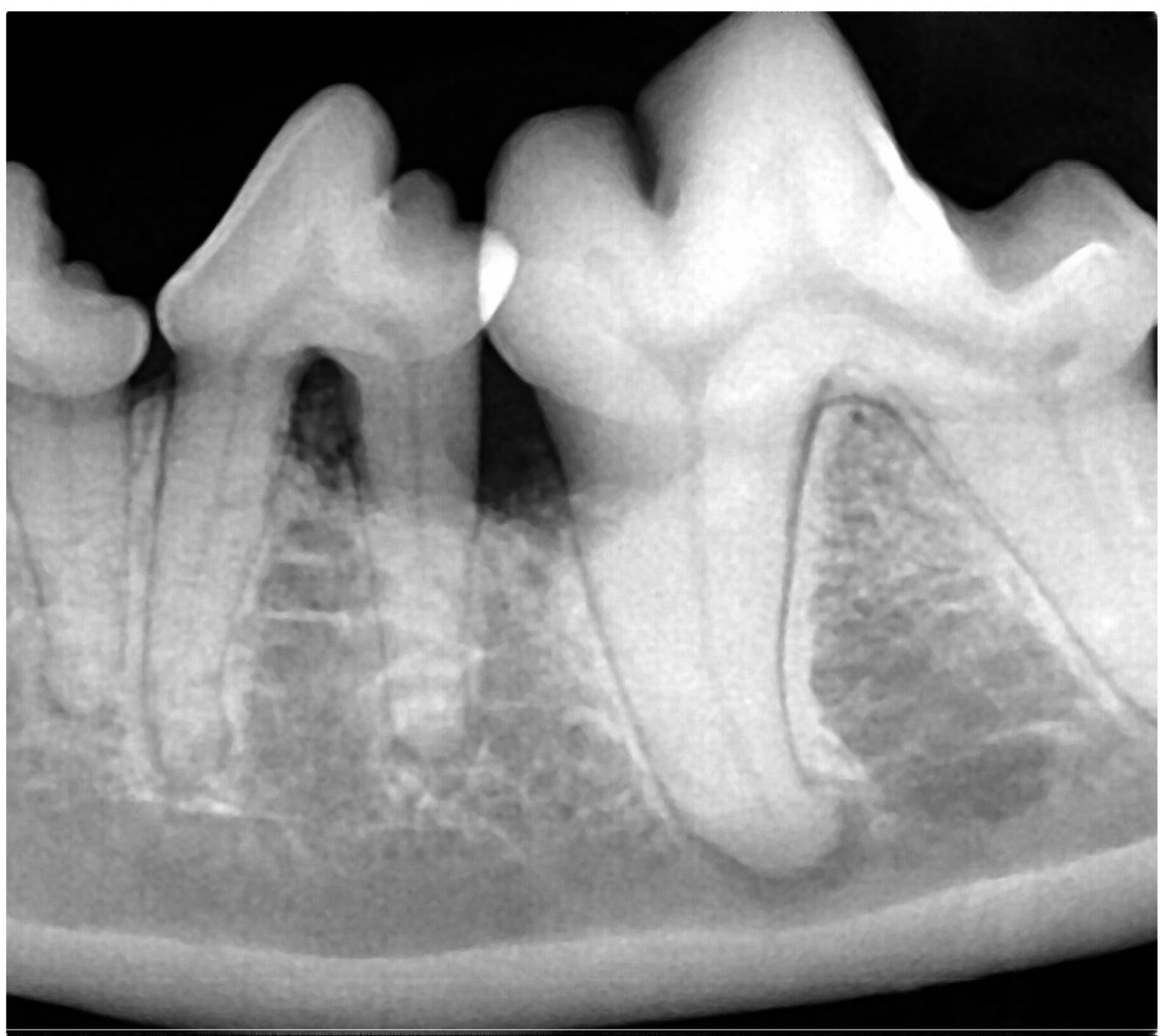

Fonte: (BAIA, 2018).

Legenda: Nesta radiografia intraoral de mandíbula esquerda de paciente canino pode-se notar a raiz distal do terceiro pré-molar (307), quarto pré-molar (308) e, de maneira incompleta, primeiro-molar (309). Radiograficamente, o dente 308 apresenta redução da densidade óssea em região de furca, pelo aspecto com maior radioluscência desta região, caracterizando estágio 2 de exposição. 
Figura 11 - Aspecto radiográfico de periodontite avançada em gato

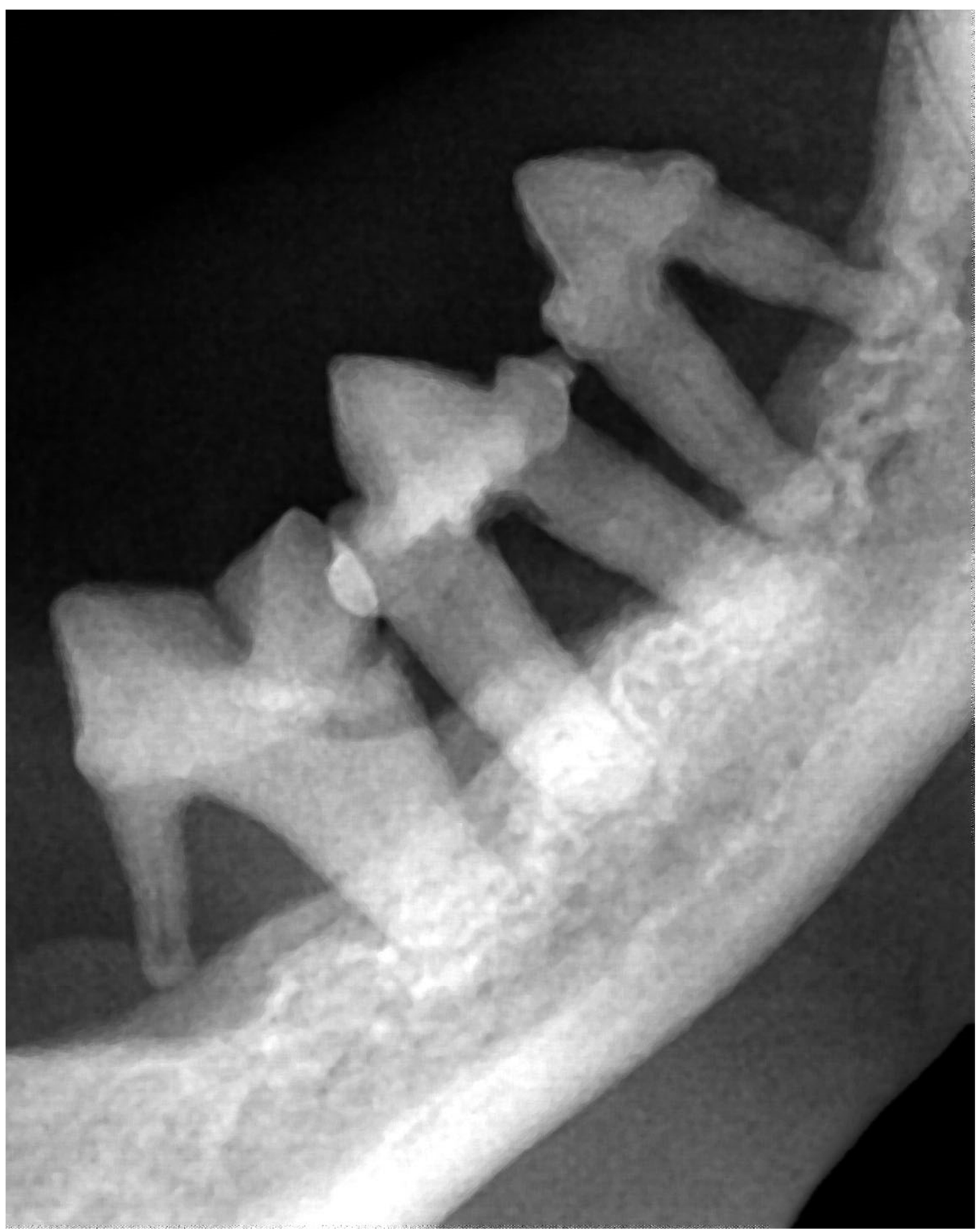

Fonte: (BAIA, 2018).

Legenda: Nesta radiografia intraoral da mandíbula direita de um paciente felino pode-se notar perda óssea maior que $50 \%$ nos dentes primeiro molar (309), quarto pré-molar (308) e terceiro pré-molar (307), caracterizando doença periodontal avançada. 


\subsubsection{Efeitos sistêmicos}

A relação entre a doença periodontal e a saúde sistêmica foi estabelecida a partir de diversos estudos epidemiológicos em seres humanos e animais. $\mathrm{Na}$ odontologia veterinária, a periodontite crônica contribui para o desenvolvimento de diversas afecções inflamatórias sistêmicas. Isto ocorre, pois os pacientes que apresentam bolsas periodontais e inflamação gengival perene, a partir de exercícios periodontais diários que incluem a mastigação, favorecem o acesso de bactérias e seus fragmentos ao sistema vascular, o que é conhecido por bacteremia. A bacteremia, por sua vez, favorece a anacorese, fenômeno que leva bactérias e seus fragmentos aos tecidos inflamados através dos vasos sanguíneos, capaz de causar infecção ou estimular a inflamação em diversos órgãos como coração, fígado, rins, órgãos do trato respiratório e também em articulações (NOACK et al., 2001; KOUKI et al., 2013; PAVLICA et al., 2008).

As interações entre patógeno e hospedeiro ocorrem através da capacidade do organismo hospedeiro em reconhecer substâncias microbianas, como ácidos nucleicos, proteínas, lipídeos de parede celular como, por exemplo, lipopolissacarídeos (LPS), e carboidratos. Tais substâncias são classificadas como Padrões Moleculares Associados a Patógenos (PMAP) e são responsáveis por caracterizar patógenos e estimular a imunidade inata (KURGAN; KANTARCI, 2017). Este reconhecimento se dá a partir de um grupo de moléculas presentes na superfície de fagócitos estrategicamente localizados na fase de reconhecimento inicial de patógenos microbianos. Este grupo é chamado de Receptores de Reconhecimento de Padrões (RRP) e, dentre eles, destacam-se os Receptores do Tipo Toll (TLR) (AKIRA; TAKEDA, 2004). Quando estes receptores são excessivamente ativados ou inadequadamente controlados, contribuem para 0 desenvolvimento de doenças crônicas inflamatórias (HAJISHENGALLIS, 2010).

Os Receptores do Tipo Toll são glicoproteínas transmembrana do tipo I que possuem um domínio extracelular classificado como Rico em Repetições de Leucina (RRL), responsável pelo reconhecimento dos Padrões Moleculares Associados a Patógenos (KURGAN; KANTARCI, 2017). 
Células epiteliais da gengiva expressam Receptores do Tipo Toll 2, 3, 4, 5, 6 e 9, essenciais para manutenção da saúde periodontal. Quando a barreira epitelial é violada por patógenos e seus produtos citotóxicos, também há ativação destes receptores presentes em células não imunes, como fibroblastos, osteoblastos e osteoclastos, resultando no acúmulo de citocinas que também contribuem para a destruição do tecido periodontal (KURGAN; KANTARCI, 2017).

Bactérias Gram-negativas, presentes em maior quantidade na periodontite, possuem Lipopolissacarídeos (LPS) como seu maior fator de virulência. Receptores do Tipo Toll 4 (TLR4) ligam-se à esta substância e, por esta razão, são considerados os receptores mais importantes para o desenvolvimento da periodontite (KURGAN; KANTARCI, 2017).

Uma das vias da cascata de sinalização dos Receptores do tipo Toll é através da proteína MyD88-dependente, que resulta na ativação do Fator de Transcrição Nuclear Kappa Beta (NFKB). Este fator de transcrição é responsável pela indução da ativação de genes inflamatórios e imunológicos, resultando na produção de citocinas inflamatórias que agravam a inflamação tecidual (KURGAN; KANTARCI, 2017; PALADINO, 2012). Deste modo, se a doença periodontal não for corretamente controlada, haverá progressiva destruição tecidual do periodonto devido à estimulação exacerbada destes receptores, que aumentam a produção de citocinas pró-inflamatórias e estimulam, continuamente, a resposta inflamatória (HANS; HANS, 2011; KURGAN; KANTARCI, 2017).

A resposta inflamatória é vital para a sobrevivência dos animais. A inflamação regula a defesa do corpo contra patógenos e estresse ambiental, além de controlar a recuperação de feridas. A inflamação aguda, em resposta à lesão tecidual ou infecção, ocorre praticamente de imediato. Esta fase é curta e normalmente resulta na recuperação do equilíbrio fisiológico. A inflamação aguda é considerada uma resposta fisiológica que ocorre em tecidos vascularizados para proteger 0 hospedeiro e manter a homeostase. O processo de inflamação aguda caracteriza-se pela dilatação vascular, aumento da permeabilidade de capilares, do fluxo sanguíneo e do recrutamento de células com função de defender o organismo, chamadas de leucócitos (HANS; HANS, 2011; KURGAN; KANTARCI, 2017; ROBINSON; COBB, 1997).

Quando permanece após o período transitório da resposta imune inata para adquirida, a inflamação torna-se crônica. Nesta fase, há aumento de atividade 
destrutiva de colágeno. Sendo o colágeno a proteína mais abundante do corpo humano e animal, presente em praticamente todos os órgãos, a inflamação crônica, ao destruir colágeno, lesiona diversos órgãos e tecidos (GELSE; POSCHL; AIGNER, 2003; LEBLEU; MACDONALD; KALLURI, 2007).

Várias modificações inflamatórias ocorrem durante a progressão da doença periodontal (CAIAFA, 2007) e quanto mais intensa e longa a inflamação gengival, maior é a resposta inflamatória sistêmica gerada pelo animal e maiores serão os dados teciduais e orgânicos (KOUKI et al., 2013).

A idade, dieta, sobrepeso ou desnutrição são alguns fatores que reduzem a competência dos mecanismos imunológicos. Porém, métodos preventivos como escovação dentaria diária, diagnóstico periodontal apropriado e o correto tratamento periodontal contribuem para a longevidade da dentição e reduzem a prevalência de diversas condições sistêmicas (HANS; HANS, 2011; KOUKI et al., 2013; PAVLICA et al., 2008). 


\subsection{TRATAMENTO PERIODONTAL}

O tratamento periodontal tem como objetivo principal eliminar 0 fator etiológico do processo inflamatório que afeta o periodonto, a partir da remoção mecânica da placa bacteriana supragengival e subgengival, além de diagnosticar e eliminar sítios facilitadores de infecção, como bolsas periodontais, hiperplasias e retrações gengivais (AIMETTI, 2014).

De acordo com o Colégio Americano de Odontologia Veterinária, antibióticos sistêmicos não devem ser utilizados no manejo preventivo da periodontite, tampouco eleitos como terapia única ao tratamento da doença periodontal. A bacteremia transitória, que ocorre durante o tratamento periodontal, consegue ser superada por pacientes saudáveis. Assim, recomenda-se a utilização de antibióticos sistêmicos para a redução da bacteremia transitória apenas em casos de pacientes submetidos ao tratamento periodontal com doença sistêmica concomitante, comprometimento imunológico ou infecção oral considerada grave (AVDC, 2018d).

Sabe-se que as estruturas neuronais, agentes mediadores e as respostas do sistema nervoso central quanto à dor em um animal assemelham-se ao ser humano, sendo então possível estabelecer comparações a respeito da sensibilidade e percepção à dor dos animais. Qualquer lesão tecidual pode levar à dor crônica, sendo esta considerada frequente após procedimentos cirúrgicos. Logo, o tratamento da doença periodontal deve ser somente realizado com 0 animal devidamente anestesiado (CAMARGO; GIOSO; CARVALHO, 2010; LAVAND'HOMME, 2017).

Para maximizar a segurança dos cães e gatos durante 0 tratamento periodontal, faz-se necessário planejamento anestésico. Durante a escolha correta da medicação pré-anestésica, busca-se reduzir o estresse do paciente, facilitar tanto a indução anestésica quanto sua recuperação, minimizar doses dos fármacos de indução e manutenção, além de auxiliar no controle de dor com suporte de terapia analgésica multimodal, a partir da associação de fármacos, e analgesia preemptiva, com a administração dos fármacos analgésicos antes do estímulo doloroso. De modo geral, utiliza-se o fármaco de indução intravenosa para permitir a colocação do tubo endotraqueal que irá estabelecer a passagem de ar junto ao fármaco de manutenção. A correta insuflação do tubo é fundamental para a realização do 
tratamento periodontal, pois impede a entrada de fluido e partículas para 0 trato respiratório do paciente. A manutenção anestésica torna seguro o procedimento cirúrgico ao eliminar os movimentos do paciente e, junto aos bloqueios anestésicos regionais, impedir sua percepção dolorosa. Assim, minimiza-se a quantidade necessária de fármacos durante o período transoperatório, melhorando também o pós-operatório imediato deste animal (BECKMAN, 2013).

Sendo considerada uma forma inadequada de conduta profissional, a limpeza dentária sem anestesia é uma prática que tem sido promovida ao público como uma alternativa ao tratamento periodontal especializado, a partir da remoção parcial e inadequada da placa bacteriana e cálculo dentário, apenas na região supragengival, em pacientes acordados. Estando acordado, o paciente corre o risco de ser ferido com os instrumentos odontológicos. Além disso, o animal sente incômodo e dor, não permite o completo exame clínico dos dentes e da cavidade oral, impossibilitando um tratamento adequado (AVDC, 2018a; MCFADDEN; MARRETTA, 2013).

A raspagem manual com curetas odontológicas em pacientes acordados ou apenas sob leve sedação não permite o acesso à região subgengival e, por esta razão, mantém a placa bacteriana e cálculo dentário nesta área. Mesmo em casos de gengivite ou periodontite inicial esta prática não é recomendada, pois também não é possível realizar, de maneira segura, o correto e completo polimento dentário, resultando, posteriormente, em uma maior retenção de placa na superfície dentária. Os proprietários sentem-se erroneamente confortados por escolherem esta opção, acreditando que a anestesia seja um risco para o animal. Porém, não é possível um efetivo tratamento periodontal sem anestesia geral inalatória e esta prática permite a progressão da doença periodontal até que haja 0 desenvolvimento de consequências locais e sistêmicas severas como a perda dentária ou agravamento de doenças sistêmicas existentes (AVDC, 2018a; MCFADDEN; MARRETTA, 2013).

Pacientes que apresentam periodontite moderada, por exemplo, necessitam da realização de técnicas específicas para a redução das bolsas periodontais e estes procedimentos não podem ser realizados com o animal acordado ou apenas sob leve sedação. Em casos de doença periodontal severa a extração dentária fazse necessária, sendo este procedimento também desaconselhado sem anestesia geral inalatória (AVDC, 2018a).

Para um correto tratamento periodontal, após a indução anestésica, deve-se fazer um exame físico completo da cavidade oral, com o uso de sonda periodontal e 
radiografia intraoral para a avaliação de todos os elementos dentários, além de inspeção das demais estruturas. A radiografia intraoral realizada em todos os dentes frequentemente revela afecções inesperadas que requerem procedimentos cirúrgicos. Tais procedimentos são, por muitas vezes, de longa duração e, por esta razão, faz-se necessária realização da anestesia geral inalatória e correta monitorização do paciente (BECKMAN, 2013).

Os aspectos a serem considerados no tratamento periodontal variam de acordo com cada estágio da doença periodontal. A caracterização dos estágios desta afecção é realizada de maneira individual a cada elemento dentário. Logo, uma mesma cavidade oral pode apresentar diferentes estágios de periodontite. Desta forma, o tratamento periodontal deve ser realizado de acordo com as necessidades específicas de cada elemento dentário do paciente, a partir da utilização de instrumentos odontológicos específicos (AVDC, 2018c).

Dentes que apresentam doença periodontal em estágio 1, gengivite, devem receber raspagem supragengival e subgengival a partir do uso de curetas odontológicas (Figuras 12 e 13) e/ou ultrassom odontológico (Figuras 14 e 15), a fim de desorganizar a placa bacteriana in loco. Posteriormente, deve-se realizar polimento dentário (Figura 16) com pasta odontológica abrasiva e taça de borracha ou escova, acoplada em caneta odontológica de baixa rotação, com o intuito de tornar lisa a superfície dentária, dificultando a aderência de placa bacteriana, além de auxiliar em uma completa desorganização do biofilme aderido (GORREL, 2010). 
Figura 12 - Utilização de cureta odontológica em nível supragengival

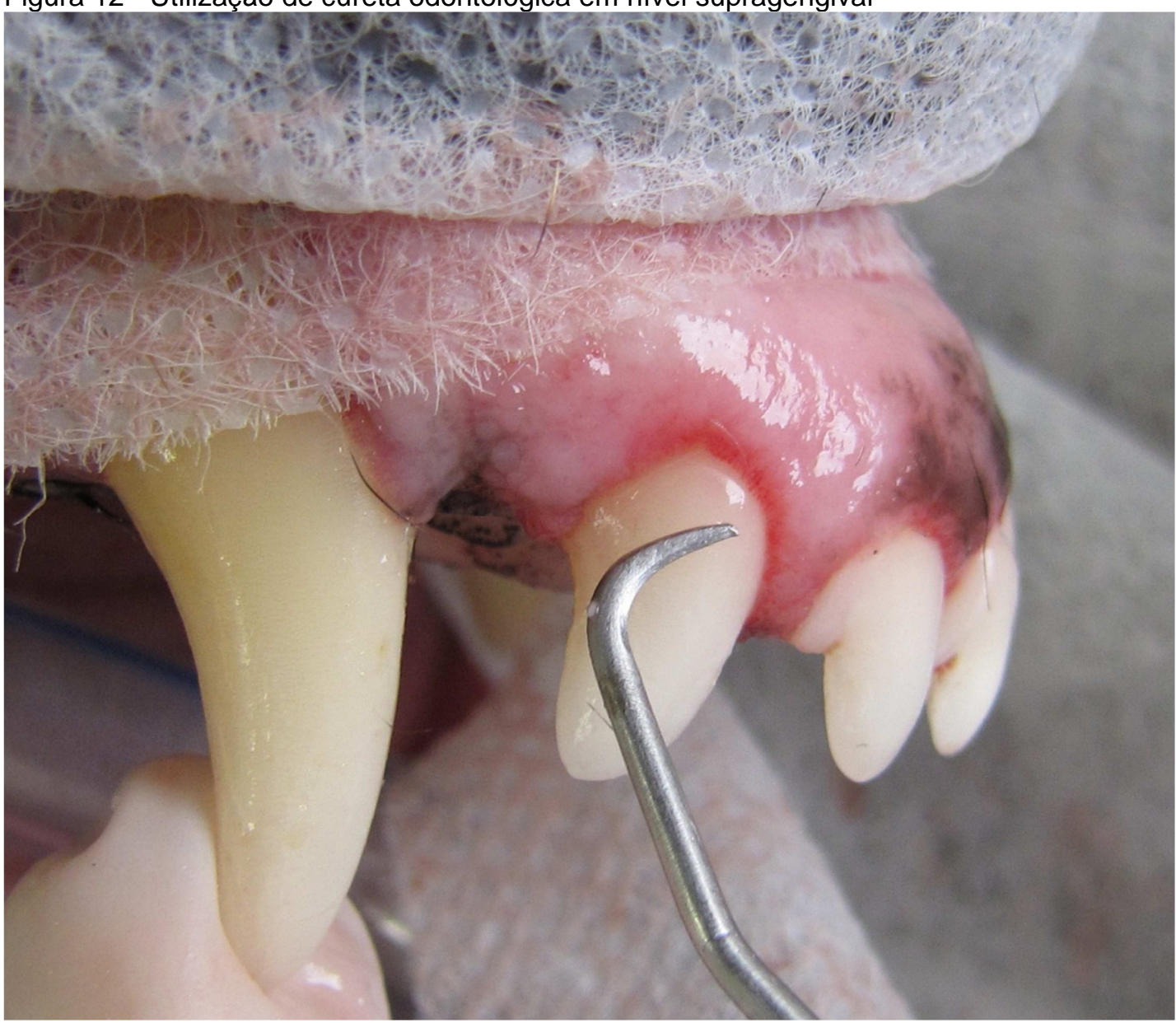

Fonte: (BAIA, 2018).

Assim como no estágio anterior, a periodontite inicial, ou estágio 2 da doença periodontal, é tratada com interrupção da progressão da destruição tecidual a partir da raspagem e polimento dentário, com intuito de prevenir o desenvolvimento de novas lesões (GORREL, 2010; LOBPRISE, 2010). 
Figura 13 - Utilização de cureta odontológica em nível subgengival

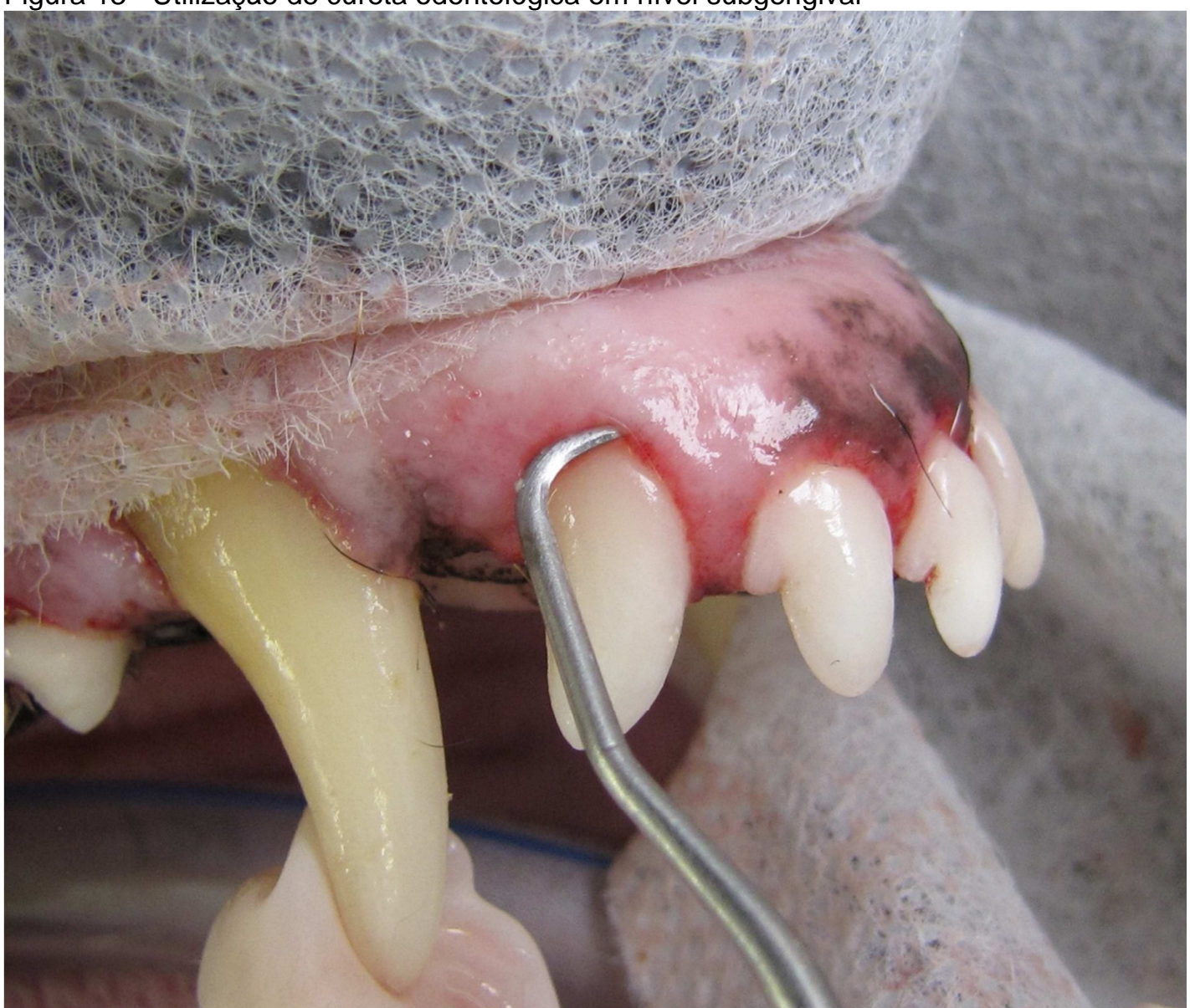

Fonte: (BAIA, 2018).

Dentes com periodontite moderada, estágio 3 da doença periodontal, devem receber raspagem e polimento. Além disso, o profissional deve eleger técnicas específicas como uso de enxertos periodontais, gengivectomias e retalhos mucogengivais, junto ao alisamento radicular realizado com curetas odontológicas específicas, devido à necessidade de tornar limpa e lisa a porção radicular que se encontra sem a devida proteção do osso alveolar (CARRANZA et al., 2012). Neste estágio, entretanto, pode-se considerar a extração dos dentes acometidos em casos de proprietários indispostos a comprometerem-se com a realização de manejo preventivo diariamente (GORREL, 2010). 
Figura 14 - Utilização de ultrassom odontológico em nível supragengival

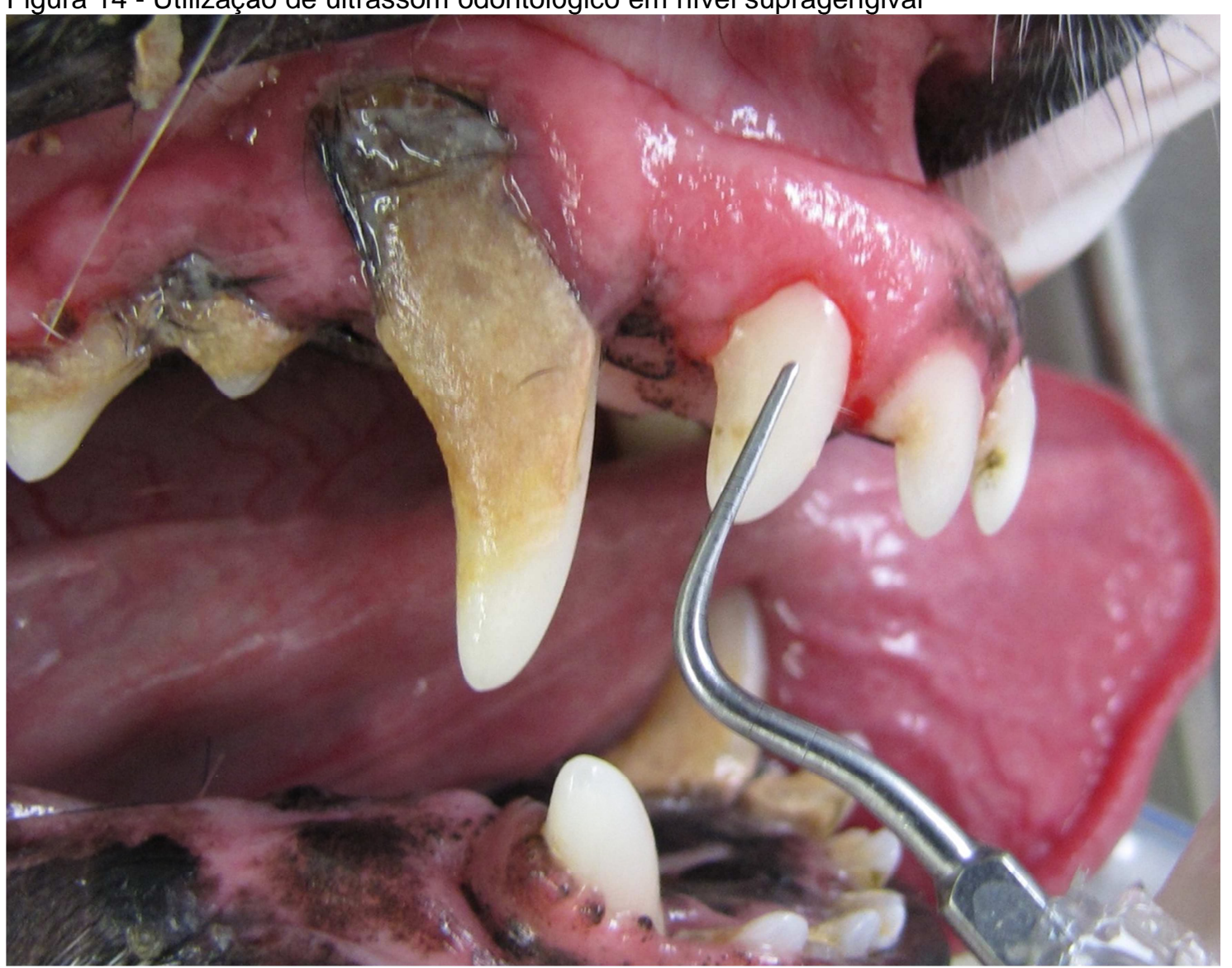

Fonte: (BAIA, 2018).

Por fim, dentes diagnosticados com estágio 4 da doença periodontal, periodontite avançada, precisam ser extraídos (GORREL, 2010). Deve-se lembrar de que, neste estágio, menos de $50 \%$ da raiz dentária apresenta fixação no osso alveolar, havendo mobilidade dentária avançada devido à extensa destruição do tecido periodontal de sustentação. Por ser um procedimento de alto grau de complexidade, a extração dentária é uma das principais causas de lesões iatrogênicas durante o tratamento periodontal em cães e gatos (GORREL, 2010, LOBPRISE, 2010). 
Figura 15 - Utilização de ultrassom odontológico em nível subgengival

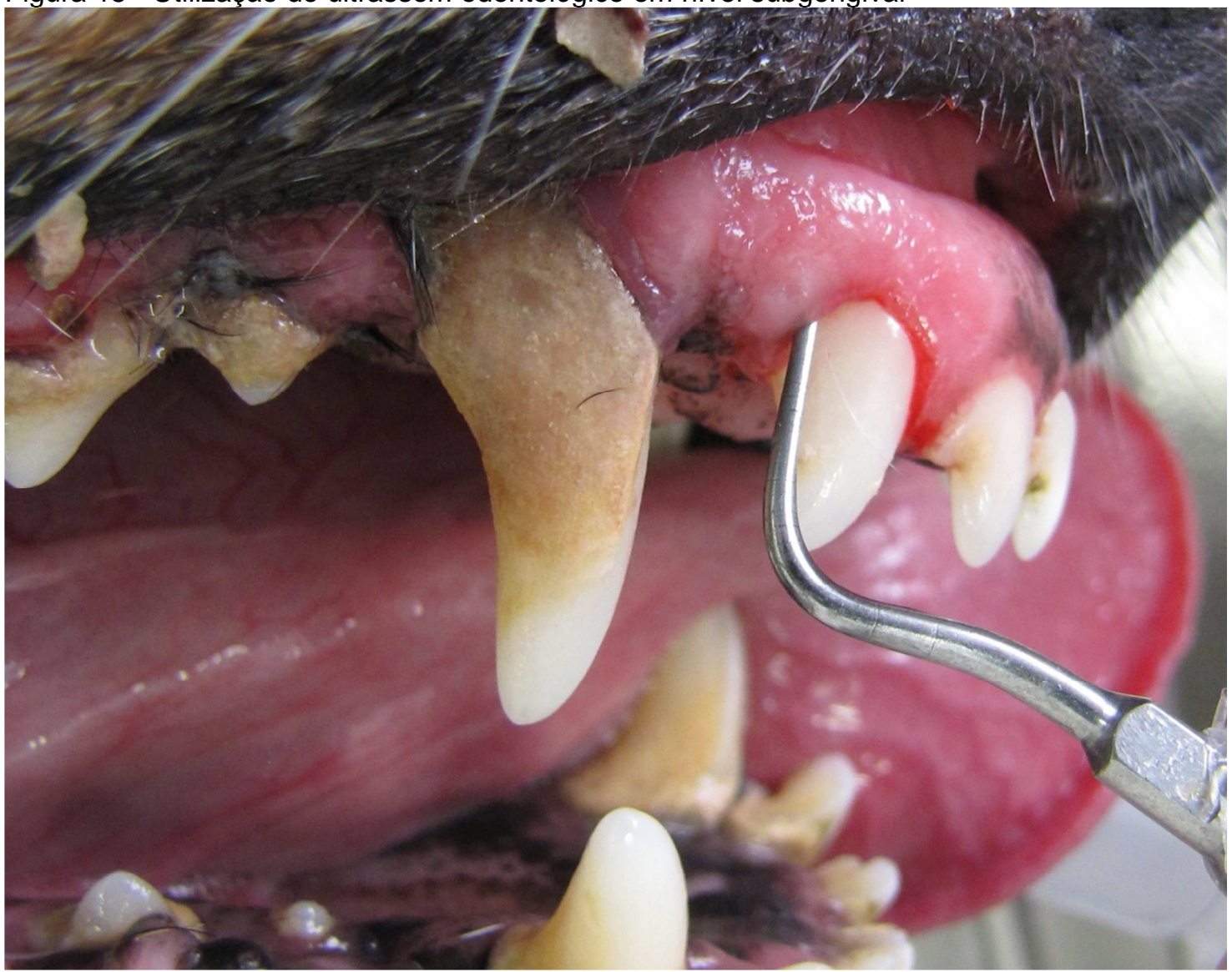

Fonte: (BAIA, 2018). 
Figura 16 - Polimento dentário em dente canino (304) de cão

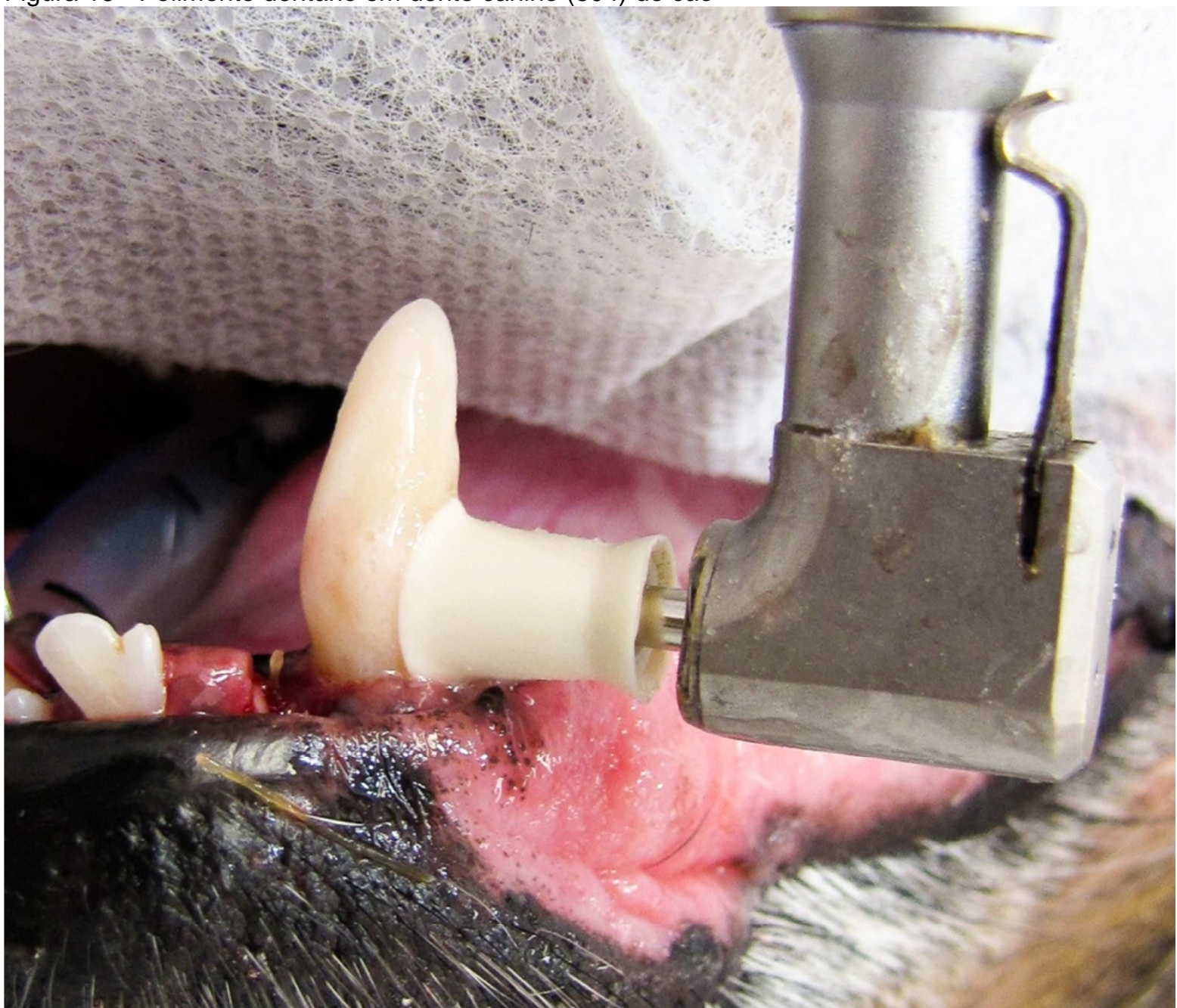

Fonte: (BAIA, 2018).

Define-se por lesão iatrogênica qualquer lesão que resulte de um ato médico (FERREIRA, 2014). Relata-se, como exemplos de lesões iatrogênicas decorrentes de tratamento periodontal de cães e gatos, a ocorrência de lesões térmicas em osso, fratura dentária, comunicação oronasal, enfisema, edema sublingual, fratura de mandíbula e maxila, hemorragia (GORREL, 2010), manifestações nasais (KANG; LIM; PARK, 2011; TAYLOR; SMITH; SNYDER, 2004), cegueira central e alterações neurológicas (STILES et al., 2012), traumas oculares (DUKE et al., 2014; GUERREIRO; APPELBOAM; LOWE, 2014; SMITH et al., 2003), surdez (STEVENSSPARKS; STRAIN, 2010), injúrias cerebrais (TROXEL, 2015), infecção local e sistêmica (REITER; BRADY; HARVEY, 2004). De acordo com o Código de Ética do Médico Veterinário, o profissional que gera lesões iatrogênicas em seu paciente está sujeito à ser responsabilizado no âmbito ético e civil (CFMV, 2016) 


\subsection{RESPONSABILIDADE CIVIL E ÉTICA DO MÉDICO VETERINÁRIO}

Considerado um tema relevante no âmbito jurídico atual, a responsabilidade civil está relacionada à ideia de reparação de danos. O conceito de responsabilidade civil, a partir do artigo 927 do Código Civil de 2002, refere-se como a obrigação de reparar dano causado a outrem. Neste sentido, a natureza jurídica da responsabilidade civil consiste em sancionar, independentemente da forma, o responsável pelo dano causado, a fim de que haja o reestabelecimento do status quo ante (DINIZ, 2017; GONÇALVES, 2017).

Pode-se classificar a responsabilidade civil em relação à presença ou ausência de culpa na violação de um dever jurídico. A responsabilidade subjetiva não permite a responsabilização de uma pessoa sem comprovação de culpa, sendo então dependente do comportamento do sujeito. Em contrapartida, na responsabilidade objetiva não há necessidade de comprovação de dolo ou culpa do sujeito, devendo apenas demonstrar-se o vínculo entre a conduta do agente e o resultado ilícito (GONÇALVES, 2017).

A lei 8.078/90 (BRASIL, 1990), mais conhecida como Código de Defesa do Consumidor, em seu artigo 14, adota por regra a responsabilidade objetiva:

Art. 14. O fornecedor de serviços responde, independentemente da existência de culpa, pela reparação dos danos causados aos consumidores por defeitos relativos à prestação dos serviços, bem como por informações insuficientes ou inadequadas sobre sua fruição e riscos.

É importante ressaltar que a referida lei aborda de maneira distinta da regra geral quando se trata de profissionais liberais. Tal lei alude no artigo supracitado que a responsabilidade pessoal dos profissionais liberais será apurada mediante a verificação de culpa, caracterizando a responsabilidade como subjetiva. Sendo assim, percebe-se que o Código de Defesa do Consumidor aborda tanto a responsabilidade civil objetiva quanto a subjetiva nas relações de consumo, tendo sua aplicação variada de acordo com cada caso concreto (CAVALIERI FILHO, 2015). 
O exercício da atividade como médico veterinário e também a criação dos conselhos regionais e federal como órgãos fiscalizadores dá-se a partir da lei 5.517/1968. Já as atribuições deste, em relação aos princípios, atividades e deveres profissionais estão descritos na resolução 722 do ano de 2002, também conhecida por Código de Ética do Médico Veterinário. Esta resolução abrange a responsabilidade subjetiva e objetiva deste profissional (PAZÓ; HEANCIO, 2014).

Ao médico veterinário confere-se a prerrogativa de atuar como profissional liberal autônomo ou vinculado a uma clínica veterinária. Como autônomo, ele deve assumir integralmente os riscos de suas atividades profissionais. Estando vinculado a uma clínica, haverá então o concurso de duas responsabilidades: a responsabilidade objetiva do empregador e a subjetiva, dele, como empregado. Sendo assim, existem diferenças com relação à responsabilidade civil do médico veterinário, pois esta dependerá da maneira em que ele atua profissionalmente (BARROS, 2017; CAVALIERI FILHO, 2003; CAVALIERI FILHO, 2015).

$\mathrm{Na}$ maioria das atividades profissionais pode haver a reparação do erro. Entretanto, na atividade médica, erros normalmente não permitem o retorno ao estado anterior, podendo até levar ao óbito do paciente. O erro médico, sendo a forma inadequada de conduta profissional que produz dano ao paciente a partir de suposta inobservância técnica no exercício da profissão, tem a responsabilidade civil como subjetiva e com culpa comprovada. Logo, existem três elementos capazes de determinar uma responsabilidade por culpa (Figura 17): negligência, imprudência e imperícia (DINIZ, 2017; GONÇALVES, 2017). Em uma avaliação realizada em 2012, cerca de dois terços das denúncias e processos éticos recebidos pelo Conselho Regional de Medicina Veterinária do estado de São Paulo (CRMV-SP) estavam relacionados a algum destes três elementos (HAGIWARA, 2017). 
Figura 17 - Elementos que determinam responsabilidade por culpa

\section{Negligência}

Conduta dita como omissiva, descuidada, sem as devidas precauções necessárias

\section{Imprudência}

Falta de cautela, conduta precipitada que não dá importância às consequências

\section{Imperícia}

Incapacidade técnica para o exercício de determinada função

Fonte: (BAIA, 2018).

A negligência consiste em uma conduta dita como omissiva, descuidada, sem as devidas precauções necessárias. Por sua vez, a imprudência é considerada a falta de cautela, conduta precipitada que não dá importância às consequências. Por fim, a imperícia é a incapacidade técnica para o exercício de determinada função (DINIZ, 2017; GONÇALVES, 2017).

Percebe-se que a partir da crescente conscientização do proprietário a respeito de seus direitos legais, facilidade de acesso à informação, além da aproximação e até mesmo humanização dos animais de estimação no núcleo familiar, o médico veterinário deve sempre manter uma postura atenta em relação aos serviços por ele prestados, acreditando na importância da educação, tanto técnica quanto ética, como ferramenta fundamental neste processo, a fim de que se reduzam as demandas administrativas e judiciais (MAGALHÃES-SANT'ANA, 2016; SLOWINSKI et al., 2016).

Em diversas áreas, a ética está associada a um bom desempenho profissional perante a sociedade. Em uma abordagem baseada em regras a ética é trazida como um conjunto de normas morais que são frequentemente expressadas através de leis, regulamentos e códigos. Estas normas refletem os princípios pelos quais a sociedade mantém o senso de comunidade (MAGALHÃES-SANT'ANA, 
2016). Neste sentido, existem diversas discussões a respeito da importância do ensino da ética na área da saúde (MAGALHÃES-SANT'ANA, 2016; PELLEGRINO; MCELHINNEY, 1982; BOUFORD; CARSON, 1984; BICKEL, 1987).

Além de prestígio e privilégios, tornar-se médico veterinário traz responsabilidade legal e ética e, junto aos altos padrões científicos exigidos pela sociedade, estes profissionais devem demonstrar fortes valores morais humanísticos. A ética, porém, não é considerado um tópico padrão ouro no ensino da medicina veterinária e, assim sendo, esta lacuna favorece a ocorrência de diversos conflitos profissionais (MAGALHÃES-SANT'ANA, 2016).

Existe uma conexão evidente entre os conceitos legais e as repercussões éticas na rotina do médico veterinário e, a partir deste vínculo, percebe-se que ser um bom profissional também diz respeito a fazer o que é considerado certo. Porém, lei e moral são conceitos distintos e não há uma regra estabelecida para toda situação que, em algum momento de suas vidas profissionais, a pessoa irá enfrentar (MAGALHÃES-SANT'ANA, 2016). Na área da saúde, dá-se muito valor para regras e protocolos, reduzindo a importância do papel da ética pela impressão de que a ética profissional é apenas uma adição à lei, sendo a lei suficiente. Logo, ética tornase aparentemente desnecessária (BROCKETT et al., 1997).

Contrapondo-se a esta aparência, princípios éticos e normas de conduta servem como pontos de ancoragem, indicando o certo e o errado, apropriado e inapropriado, de acordo com os padrões universais estabelecidos. Percebe-se que ao oferecer regras de conduta, a ética busca fornecer um ponto fixo de referência em uma sociedade em constante transformação. Assim sendo, é a partir da ética que o profissional entende o que se espera dele (MAGALHÃES-SANT'ANA, 2016).

O reconhecimento do papel da ética na educação para a prevenção do erro médico deve ser discutido de maneira ampla e persistente (BITENCOURT et al., 2007), devendo ser levado em consideração a grande quantidade de escolas de medicina veterinária neste país, número que hoje representa um terço dos cursos formadores desta profissão ofertados em todo o mundo (LÔBO; MACHADO, 2018).

Além da ética, é necessário que o médico veterinário tenha domínio técnico para a realização de sua atividade profissional, sendo o processo ensinoaprendizagem uma estratégia importante na área da saúde para a prevenção do erro médico (MAGALHÃES-SANT'ANA, 2016; SULMASY, 2000). 
A educação em saúde é um processo político-pedagógico que requer 0 desenvolvimento de um pensar crítico e reflexivo, propondo ações transformadoras. $\mathrm{Na}$ área da saúde, o estudo e uso de métodos para informar e influenciar as decisões individuais e coletivas que geram melhoria na saúde é conhecido por comunicação em saúde. Esta é uma importante estratégia na promoção da saúde por conseguir ampliar o conhecimento de um indivíduo, expondo problemas e soluções pertinentes, influenciando percepções, crenças, atitudes e até normas sociais. A comunicação em saúde também pode ser utilizada para demonstrar habilidades técnicas e estimular mudança de comportamento. Por fim, este artifício pode ser útil para aumentar a demanda de certos serviços especializados, reforçar conhecimentos, refutar mitos e inverdades, além de defender questões (MACHADO et al., 2007; MOREIRA; NÓBREGA; SILVA, 2003).

No âmbito da saúde, a educação constantemente discute a desconstrução de paradigmas (FERRO, 2012), modelos ou padrões científicos a serem seguidos (FERREIRA, 2014) que surgem com o objetivo de solucionar problemas existentes (FERRO, 2012). Côrtes (2006) afirma que esta ferramenta é de suma importância para o desenvolvimento da ciência, sendo usada para embasar a tomada de decisões dos profissionais. A medicina veterinária, como todas as outras ciências, sustenta-se através de paradigmas (FERRO, 2012). Após certo tempo, porém, percebe-se a diminuição da capacidade de um modelo científico em resolver problemas e, neste momento, o paradigma entra em um período de estagnação, devendo ser considerada sua substituição (CÔRTES, 2006).

Kuhn (1998) alega que o sucesso de um novo paradigma é determinado por sua capacidade de resolver problemas não solucionados pelo paradigma anterior. Este período crítico, representado por um desequilíbrio entre o conjunto de descobertas e as condutas tomadas pelos profissionais, estimula a sociedade científica a questionar e abandonar conhecimentos vigentes (CÔRTES, 2006).

Neste sentido, a odontologia veterinária tenta estabelecer paradigmas através de novas condutas e modelos científicos em prol da saúde e qualidade de vida dos cães e gatos (CAIAFA, 2007; CLARKE; CAMERON, 1998; GORREL, 2010; 
HARVEY, 1998; KOUKI et al., 2013; MCFADDEN; MARRETTA, 2013; NIEMIEC et. al., 2018; PAVLICA et al., 2008).

\subsubsection{Processo ensino-aprendizagem}

O conjunto de normas pedagógicas que define a educação e assegura a aprendizagem é dependente de um complexo sistema de interações comportamentais entre professores e alunos, denominado processo ensinoaprendizagem (KUBO; BOTOMÉ, 2001; MAGALHÃES-SANT'ANA, 2016). Ensinar e aprender são atividades constituídas por diversos comportamentos que interagem entre si e são, por vezes, de difícil percepção. Para compreender este processo, deve-se notar a interdependência entre ambos os conceitos. A relação interativa entre professor e aluno dá sentido ao processo educativo, pois no coletivo os sujeitos também elaboram conhecimento (KUBO; BOTOMÉ, 2001; SILVA; NAVARRO, 2012).

Aprender é um processo que acompanha alguns sentimentos importantes como curiosidade, tensão, ansiedade, angústia, entusiasmo, frustração, alegria, impaciência e obstinação, que surgem durante $o$ ato de perceber, analisar, comparar e entender. Pode-se então deduzir que o aumento de conhecimentos não é apenas quantitativo, por basear-se no volume de informações acumuladas no cérebro humano. A aprendizagem gera mudanças qualitativas, simultaneamente, que são trabalhadas de maneira integral pelo educando (BORDENAVE; PEREIRA, 1998). Ela decorre de experiências individuais e coletivas, dependendo dos estímulos ambientais, e seu grau depende do indivíduo, do professor e do meio. De acordo com Paulo Freire (1992, p.27): "Só aprende aquele que se apropria do aprendido transformando-o em apreendido, com o que pode por isso mesmo, reinventá-lo; aquele que é capaz de aplicar o aprendido-apreendido a situações existentes concretas".

Pela perspectiva cognitivista, o ato de aprender, ou seja, de aquisição e retenção de conhecimentos, é um processo de compreensão das relações entre condições externas que são mediadas por condições internas e, também, um processo de doação de sentido e significado para as situações em que o indivíduo 
se encontra (SACRISTÁN; GÓMEZ, 2007). Nota-se que a distinção psicológica entre conteúdo e forma é decisiva para as formulações normativas da didática. Ao distingui-los, é estabelecida a base de uma concepção didática de ações sensoriais, motoras e mentais que subordina a imagem e a intuição à atividade e operação. Como personagem principal do processo ensino-aprendizagem, o aluno passa a ter a autonomia da sua aprendizagem, valorizando a importância do seu crescimento individual para o desenvolvimento do coletivo (PIAGET, 1976; SACRISTÁN; GÓMEZ, 2007; SANTOS, 2001).

Durante a aprendizagem, a autonomia se dá na identificação da capacidade de o aluno responsabilizar-se pela própria formação. Desta maneira, a autonomia tida na aprendizagem influencia de modo direto e positivo características como agilidade e proatividade (GOTTARDI, 2015). Cartilhas e manuais educativos podem apresentar uma valiosa contribuição para o desenvolvimento de habilidades e favorecimento da autonomia do indivíduo (TORRES et al., 2009). De acordo com Dewey (1916), a atividade autônoma é considerada fundamental, pois através de suas próprias observações, reflexões, formulações e sugestões, alunos apresentam maiores condições de ampliar conhecimentos prévios existentes.

Ensinar não se limita à transmissão de conhecimento, mas a adequar o conteúdo à realidade do aluno. $O$ ensino consiste na resposta planejada às exigências naturais do processo de aprendizagem (SANTOS, 2001; SILVA; NAVARRO, 2012). Ele existe apenas se houver aprendizagem e o sucesso do processo ensino-aprendizagem depende do aluno, pois este aprende somente se quiser (PARO, 2016). É senso comum entre os educadores que o desinteresse dos alunos seja um dos grandes problemas que interferem diretamente no processo ensino-aprendizagem. Deste modo, é necessário que o conjunto de informações novas seja intrinsecamente desejável para que o aluno queira aprender. Sendo assim, torna-se dever do educador levar o educando a querer aprender, pois aquele deve buscar auxílio nas mais diversas teorias pedagógicas, no intuito de compreender o processo educativo e ser capaz de estimular neste o tão esperado aprendizado (PARO, 2016; SILVA; NAVARRO, 2012).

De acordo com David Ausubel (1962) considera-se o princípio norteador da teoria educacional cognitivista a habilidade do educador em identificar o conhecimento prévio que o educando já possui e, a partir disto, desenvolver conexões entre o conhecimento já adquirido e as novas informações que serão 
dadas. Porém, quando não há conhecimento prévio a respeito do tema, deve-se optar pela aprendizagem mecânica, a basear-se em memorização (SANTANA; CARLOS, 2013; SILVA; SCHIRLO, 2014).

De acordo com a perspectiva dada pela tendência pedagógica liberal renovada progressivista, defendida por autores como Piaget (1973) e Anísio Teixeira (1957), ao professor permite-se assumir apenas o papel de facilitador, tornando o aluno livre para o ato de aprender (PIAGET, 1976; SACRISTÁN; GÓMEZ, 2007; SANTOS, 2001).

\subsubsection{Materiais educativos}

As formas mais comuns utilizadas na comunicação em saúde são materiais educativos como, por exemplo, cartilhas e manuais (MACHADO et al., 2007; MOREIRA; NÓBREGA; SILVA, 2003). Considerados importantes meios facilitadores da aprendizagem, estes materiais devem ser formulados em associação à realidade sociocultural dos educandos, tornando-se atrativos e provocando a curiosidade do aluno, para que a aprendizagem seja significativa e eficaz, estimulando habilidades e desenvolvendo o aprendiz no aspecto social, intelectual e pessoal (GIORDANI; MENDES, 2007).

Difundir informações sobre educação em saúde apresenta um importante papel na aquisição de poder técnico e influência de fatores determinantes para a saúde e bem estar. Mesmo sendo considerados importantes no complemento ao processo ensino-aprendizagem, há certa dificuldade em encontrar material de apoio pedagógico para educação em saúde que atenda às necessidades dos profissionais (ZOMBINI; PELICIONI, 2011). 


\subsubsection{Desenvolvimento}

O desenvolvimento de materiais destinados à promoção da saúde é de suma importância no processo de educação profissional continuada, pois contribuem como ferramenta de apoio pedagógico (SACRISTÁN; GÓMEZ, 2007).

Defende-se a construção de todo e qualquer material educativo a partir da fundamentação no conceito de significação lógica, ou seja, devendo haver coerência em sua estrutura interna elaborada, existindo uma sequência lógica nos processos descritos e apresentando as consequências nas relações entre seus elementos constituintes. Além disto, deve haver a presença de significação psicológica, ou seja, a compreensão de todo o conteúdo exposto (SACRISTÁN; GÓMEZ, 2007).

Percebe-se que, na criação de materiais educativos, a informação científica é um dado fundamental para o desenvolvimento de atitudes preventivas em seu público-alvo (ABDUCH, 1999). Destaca-se a importância da conduta ética para o desenvolvimento de materiais educativos (TORAL; CONTI; SLATER, 2009), pois com o intuito de garantir confiabilidade, o conteúdo deve ser elaborado com base em literatura científica (REBERTE; HOGA; GOMES, 2012).

$\mathrm{Na}$ odontologia veterinária, destacam-se como fontes de conteúdo científico específico: o Colégio Americano de Odontologia Veterinária (American Veterinary Dental College - AVDC) e a Revista Científica de Odontologia Veterinária (Journal of Veterinary Dentistry - JOVD). Reconhecido pela Associação Americana de Medicina Veterinária, o Colégio Americano de Odontologia Veterinária é uma organização para médicos veterinários especializados em odontologia veterinária, cujo principal objetivo é determinar os requisitos padrões para o reconhecimento de especialistas nesta área, além de atuar na prevenção de doenças orais com o fornecimento de informação (AVDC, 2018e). Por sua vez, o Journal of Veterinary Dentistry (JOVD) é uma revista científica que aborda exclusivamente assuntos da odontologia veterinária (SAGE, 2018).

Por tratar-se de conteúdo científico destinado aos profissionais não especializados na área, para que possa ser mais bem compreendido enquanto estiver sendo ensinado, faz-se necessário modificá-lo. A este fenômeno dá-se o nome de transposição didática, um conceito proposto a partir de uma análise do sistema didático para adaptar o conhecimento científico, transformando-o em 
conhecimento escolar, tornando-o especialmente estruturado para ser ensinado (CHEVALLARD, 1998). Esta ferramenta pedagógica, utilizada na elaboração do conteúdo deste material didático, possibilitou que o conhecimento construído fosse de linguagem adequada à compreensão do público de destino, a partir da seleção ou recorte dos conteúdos, hierarquização, divisão e reforço dos temas, além da organização sequencial pelo autor.

Também considerada importante, a seleção das cores contidas no material educativo devem ser cuidadosamente escolhidas e combinadas, a partir da leitura de pesquisas relacionadas à sua importância, para o desenvolvimento das emoções humanas e também para estimular o aprendizado e capacidade de memorização (HANADA, 2017; HEMPHILL, 1996; URAL; AKBAY; ALTAY, 2017; WRIGHT; RAINWATER, 1962).

Com o intuito de melhorar e facilitar o processo de memorização de um material educativo sugere-se a utilização de organizadores gráficos como fluxogramas e mapas conceituais, considerados excelentes ferramentas de auxílio que, além de remeterem-se aos tópicos encontrados previamente durante a leitura, criam novos gatilhos de memória e reorganizam a estrutura textual (DELL'ISOLA, 2010, 2012; MOORE; READENCE, 1984).

\subsubsection{Validação}

A validação tem por objetivo a comprovação de eficácia da aplicabilidade de um instrumento didático (FREITAS et al., 2012). Em pesquisas na área da saúde, sugere-se a realização da validação do conteúdo do material elaborado a partir de um levantamento de dados, pois tal procedimento verifica a adequação das informações presentes no material desenvolvido (RIBEIRO et al, 2013).

Para realizar um levantamento de dados, necessita-se construir um questionário. Este instrumento de pesquisa é constituído por diversas questões a respeito de um tema específico. Os questionários devem ser elaborados a partir da transformação da informação desejada em um conjunto de perguntas, de modo a minimizar os erros nas respostas. Deve-se garantir a padronização e comparação de dados obtidos para aumentar a velocidade e precisão dos registros, facilitando 0 
processamento dos dados. Eles podem ser aplicados em diversas unidades de pesquisa, como grupo de pessoas, domicílios, empresas, instituições e etc. (GÜNTHER, 2003; VIEIRA, 2009).

Entre os métodos para levantamentos de dados, o estudo transversal caracteriza-se como coleta de dados em um período específico de tempo com o objetivo de responder a uma questão que acontece naquele momento (BORDALO, 2006). Quando o pesquisador busca classificar, ordenar ou medir variáveis para apresentar estatísticas, comparar grupos ou estabelecer associações, a pesquisa em questão é do tipo quantitativa, tendo caráter descritivo e podendo ser generalizável caso sejam utilizadas técnicas estatísticas (VIEIRA, 2009).

A literatura apresenta diversidade no que diz respeito ao número ideal de avaliadores para o processo de validação de conteúdo (PEREIRA, 2014). Bojö et al. (2004) e Cruz (2015) sugerem a utilização de 6 especialistas. Para Rubio et al. (2003), 6 a 20 avaliadores são suficientes para executar esta função sendo que, ao utilizar um número maior de especialistas, haverá maior coleta de informações a respeito dos itens avaliados. Em 2014, Pereira utilizou 9 avaliadores. Por sua vez, Oliveira, Fernandes e Sawada (2008) validaram o conteúdo de seu material educativo a partir de 14 especialistas. Em 2014, Oliveira, Lopes e Fernandes utilizaram 22 avaliadores.

Para Pasquali (1998), deve haver a necessidade de concordância de, pelo menos, $80 \%$ entre os avaliadores para servir como critério de decisão sobre a pertinência de cada item. A validação do conteúdo do material elaborado deve ser feita a partir da utilização de métodos como questionários e escalas de respostas, para posterior levantamento de dados (RIBEIRO et al, 2013).

A formulação das perguntas deve obedecer ao princípio de necessidade, ou seja, perguntas que não apresentem resultados que interessem diretamente ao problema da pesquisa não devem estar inseridas no questionário. Devem ser usadas palavras de acordo com o nível de vocabulário do entrevistado, evitando complexidade (CHAGAS, 2000; VIEIRA, 2009).

Para possibilitar a análise estatística, a resposta deve ser quantitativa, ou seja, com variável numérica. Além disso, devem ser fechadas, necessitando que o respondente opte por uma das opções de resposta que lhe foram apresentadas (CHAGAS, 2000; VIEIRA, 2009). Em questões fechadas, podem-se oferecer diversos tipos de respostas (GÜNTHER; JÚNIOR, 2012). 
Respostas binárias permitem apenas dois tipos de resposta, como sim ou não. As respostas de múltipla escolha, por sua vez, permitem várias opções. Respostas escalonadas são outro tipo, que apresentam alternativas organizadas em escala, de maneira que o respondente indique o seu posicionamento diante da pergunta (GÜNTHER; JUNIOR, 2012).

Existem diversos modelos de escala utilizadas em questionários, como por exemplo, a escala diferencial semântica, de Stapel, de rating horizontal e vertical, escala numérica comparativa de soma constante, de termômetro, de ordem, pictural, de escolha múltipla simples, do tipo check-list, dicotômica simples, seleção comparativa de cartões, Q-sort, escala de não compromisso e de Likert (AGUIAR; SOARES, 2012; VIEIRA, 2009).

$\mathrm{Na}$ elaboração de um projeto de pesquisa quantitativa, a definição de escalas ou alternativas adequadas de respostas deve ser feita com muito zelo. A escala de Likert atua com maior frequência em pesquisas sociais, tendo por objetivo medir a intensidade, opiniões e atitudes do respondente, a partir de uma série graduada de itens dentre os quais o indivíduo deve assinalar apenas uma das opções que melhor correspondem à sua percepção sobre o fato inquirido. Após a formulação das questões que serão integrantes do instrumento de pesquisa, é preciso decidir quantos níveis de escala serão considerados para a obtenção das informações do público-alvo (VIEIRA, 2009). Sugere-se o uso de escalas em cinco alternativas: discordância total, discordância parcial, indiferença, concordância parcial e concordância total, sob a justificativa de extrair uma informação mais rica do respondente por permitir que o entrevistado ofereça mais detalhes de sua percepção. Como desvantagem, uma má definição de categorias pode não representar bem todas as possibilidades de resposta para uma questão (GÜNTHER, 2003; LIKERT, 1932; MCCLELLAND, 1976). Um requisito básico para definir uma escala adequada é o equilíbrio entre as respostas positivas e negativas, podendo ou não apresentar uma categoria neutra. A utilização de uma resposta neutra na escala garante uma análise não tendenciosa dos dados (GUNTHER; JUNIOR, 2012).

A escala de Likert pode apresentar quatro efeitos de tendência. $O$ primeiro deles é o efeito de ordem, que justifica a tendência para a esquerda que as escalas preenchidas apresentam. Outro efeito, de aquiescência, justifica a tendência para dizer sim nas questões com que o entrevistado não concorda e tampouco discorda. O terceiro efeito é a tendência central, que justifica a relutância dos 
inquiridos em usar posições extremas. O último efeito é de resposta padrão, ocorrendo quando o entrevistado entra na rotina de escolher as opções em um padrão como, por exemplo, sempre escolher a terceira opção. Apesar destes possíveis efeitos, esta ferramenta ainda é considerada com uma opção segura para a aquisição da percepção do entrevistado em relação às informações específicas apresentadas (GÜNTHER, 2003; VIEIRA, 2009). 


\section{OBJETIVOS}

\subsection{OBJETIVOS GERAIS}

Desenvolver e validar um material educativo a respeito da doença periodontal em cães e gatos, a fim de reduzir a ocorrência de diagnósticos e tratamentos incompletos ou incorretos desta afecção, considerada a mais comumente encontrada nestas espécies, oferecendo-o como proposta de educação complementar aos médicos veterinários não especializados, porém atuantes em odontologia veterinária.

\subsection{OBJETIVOS ESPECÍFICOS}

- Buscar na literatura, através de uma revisão sistemática, subsídios para embasar a construção da cartilha educativa;

- Desenvolver um questionário para ser utilizado como instrumento de avaliação do conteúdo, aspectos visuais e aplicabilidade da cartilha;

- Ressaltar a importância do papel de materiais educativos desenvolvidos para as especialidades veterinárias, visto que diversas habilidades técnicas específicas são frequentemente exercidas por profissionais não qualificados;

- Ressaltar a importância do papel da ética, junto ao conhecimento técnico específico, para a redução de lesões iatrogênicas decorrentes de falhas diagnósticas e terapêuticas relacionadas à doença periodontal em cães e gatos;

- Disponibilizar gratuitamente e em formato digital, após validação, a cartilha educativa desenvolvida neste projeto, para médicos veterinários de todo 0 território nacional. 


\section{MATERIAL E MÉTODO}

\subsection{DELINEAMENTO DO ESTUDO}

Este estudo trata da elaboração e avaliação de uma cartilha educativa a respeito da doença periodontal em cães e gatos, como proposta de educação complementar, destinada aos médicos veterinários atuantes na clínica médica e cirúrgica de pequenos animais em todo o território nacional. O presente trabalho foi constituído a partir de uma pesquisa metodológica de desenvolvimento, de caráter não experimental e descritivo, tendo como principais focos a criação e validação de uma nova ferramenta educativa. Este tipo de abordagem utiliza os conhecimentos científicos já existentes, com o objetivo de elaborar uma nova interação destes com seu público-alvo, criando um instrumento que, neste caso, trata-se de uma cartilha, além de tornar tal instrumento confiável por meio do mecanismo de validação (POLIT; BECK, 2011).

\subsection{PROCESSO DE ELABORAÇÃO DA CARTILHA}

Para o delineamento da cartilha, utilizou-se o referencial metodológico de Echer (2005), que consiste em três etapas para a sua construção: elaboração do projeto e submissão ao comitê de ética, seleção do conteúdo e transformação de sua linguagem para torná-la mais acessível e, por fim, validação do material.

Sendo assim, o projeto foi submetido à Comissão de Ética da Faculdade de Medicina Veterinária e Zootecnia da Universidade de São Paulo, estando de acordo com os princípios éticos desta instituição.

A partir de uma revisão não sistemática, as informações que compuseram o material foram escolhidas e sintetizadas, mantendo o rigor científico do material.

O conteúdo da cartilha foi selecionado a partir de informações oferecidas pelo Colégio Americano de Odontologia Veterinária (AVDC), além de artigos científicos publicados na Revista Científica de Odontologia Veterinária (JOVD). Definiu-se, para 
seu conteúdo, tópicos relacionados à anatomia dentária do cão e do gato, etiologia, sinais clínicos, efeitos sistêmicos, diagnóstico e tratamento da doença periodontal, aspectos legais da responsabilidade civil durante a execução do tratamento periodontal nestes pacientes, além de esclarecimentos a respeito de erros conceituais comuns.

Ademais, utilizou-se de organizadores gráficos, como mapas conceituais e quadros de fluxo, com o intuito de melhorar e facilitar o processo ensinoaprendizagem.

A diagramação foi feita com softwares pertencentes à Adobe ${ }^{\circledR}$ Systems Incorporated: Indesign $\AA$ CC 2017 e Illustrator ${ }^{\circledR}$ CC 2017. As imagens contidas neste material foram obtidas a partir de arquivo pessoal e bancos de dados digitais Royalty Free, ou seja, livres de direitos autorais. Realizou-se o tratamento de todas as imagens com o software Photoshop ${ }^{\circledR}$ CC 2017, também pertencente à Adobe $\AA$ Systems Incorporated. Para este projeto, uma ilustração foi integralmente desenvolvida pelo software Illustrator ${ }^{\circledR}$ CC 2017. Os organizadores gráficos foram desenvolvidos através do SmartArt, uma ferramenta do software Word® 2016, pertencente à Microsoft ${ }^{\circledR}$ Corporation.

O material foi desenvolvido e organizado de modo a tornar-se atrativo, objetivo, pouco extenso e de fácil compreensão a partir dos textos e ilustrações. 


\subsection{PROCESSO DE VALIDAÇÃO DA CARTILHA}

Propôs-se a validação da cartilha educativa a partir de um questionário (apêndice a), desenvolvido para este fim. A escolha dos participantes deste estudo foi realizada a partir de amostragem não probabilística e intencional, excluindo qualquer processo aleatório de seleção. Deste modo, foram convidados como avaliadores, vinte médicos veterinários atuantes no território nacional, com inscrições profissionais ativas no Conselho de Medicina Veterinária e pós-graduados em odontologia veterinária em nível stricto sensu ou lato sensu.

Informações referentes ao conteúdo, aspectos visuais e aplicabilidade foram dispostas como afirmações, em um questionário disponibilizado na plataforma digital de formulários Google $\Theta$ Forms, pertencente a Google $\AA^{\circledR}$ Limited Liability Company. A validação da cartilha educativa foi realizada através da avaliação das respostas obtidas pelo questionário desenvolvido (ECHER, 2005). As respostas foram apresentadas em escala numérica (Figura 18), posteriormente a uma legenda com descrição de seus níveis de concordância, sendo eles: 1 = concordo totalmente; 2 = concordo parcialmente; $3=$ indiferente; 4 = discordo parcialmente; 5: discordo totalmente (LIKERT, 1932).

Figura 18 - Escala de respostas

\begin{tabular}{|lllllll|}
\hline & 1 & 2 & 3 & 4 & 5 & \\
$\begin{array}{|lllll|}\text { Concordo } \\
\text { totalmente }\end{array}$ & 0 & 0 & $\bigcirc$ & $\bigcirc$ & $\bigcirc$ & $\begin{array}{c}\text { Discordo } \\
\text { totalmente }\end{array}$ \\
\hline
\end{tabular}

Fonte: (BAIA, 2018).

Cada afirmação foi avaliada individualmente. Considerou-se validada a afirmação que apresentava, pelo menos, $80 \%$ das respostas entre as opções "concordo totalmente" e "concordo parcialmente" (PASQUALI, 1998).

A coleta de dados, por sua vez, foi do tipo transversal, quantitativa e generalizável (BORDALO, 2006; VIEIRA, 2009). Os dados obtidos foram tabulados e analisados por estatística descritiva (POLIT; BECK, 2011). 


\section{RESULTADOS}

Desenvolveu-se, neste projeto, uma cartilha educativa (apêndice b) composta por 28 páginas dimensionadas em $210 \times 297 \mathrm{~mm}$, predominantemente nas cores marrom, branco, preto e amarelo, digitalizada em formato tipo Portable Document Format (PDF).

\subsection{RESULTADOS OBTIDOS PELO QUESTIONÁRIO}

\subsubsection{Características dos avaliadores}

A faixa etária predominante entre os respondentes do questionário foi de 31 a 40 anos de idade (Gráfico 1). Em sua maioria, os respondentes eram do sexo feminino (Gráfico 2).

Gráfico 1 - Dados referentes à idade dos participantes do estudo, obtidos a partir do questionário de avaliação da cartilha educativa - FMVZ - São Paulo - 2018

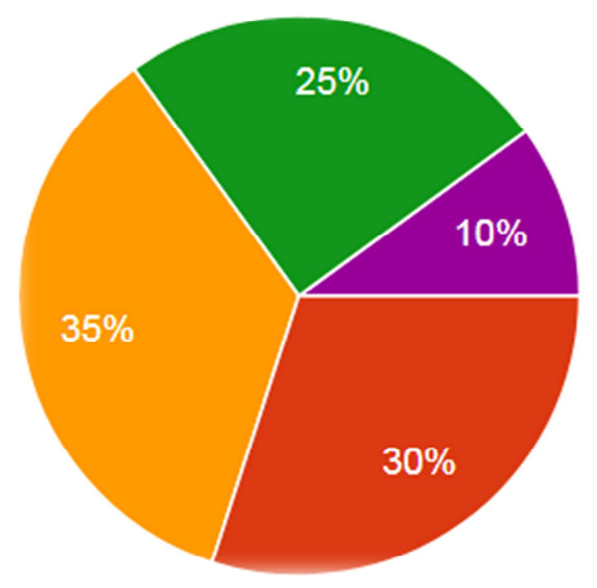

Menor que 20 anos

21 - 30 anos

31 - 40 anos

$41-50$ anos

$51-60$ anos

$61-70$ anos

Maior que 70 anos

Fonte: (BAIA, J. D., 2018). 
Gráfico 2 - Dados referentes ao sexo dos participantes do estudo, obtidos a partir do questionário de avaliação da cartilha educativa - FMVZ - São Paulo - 2018

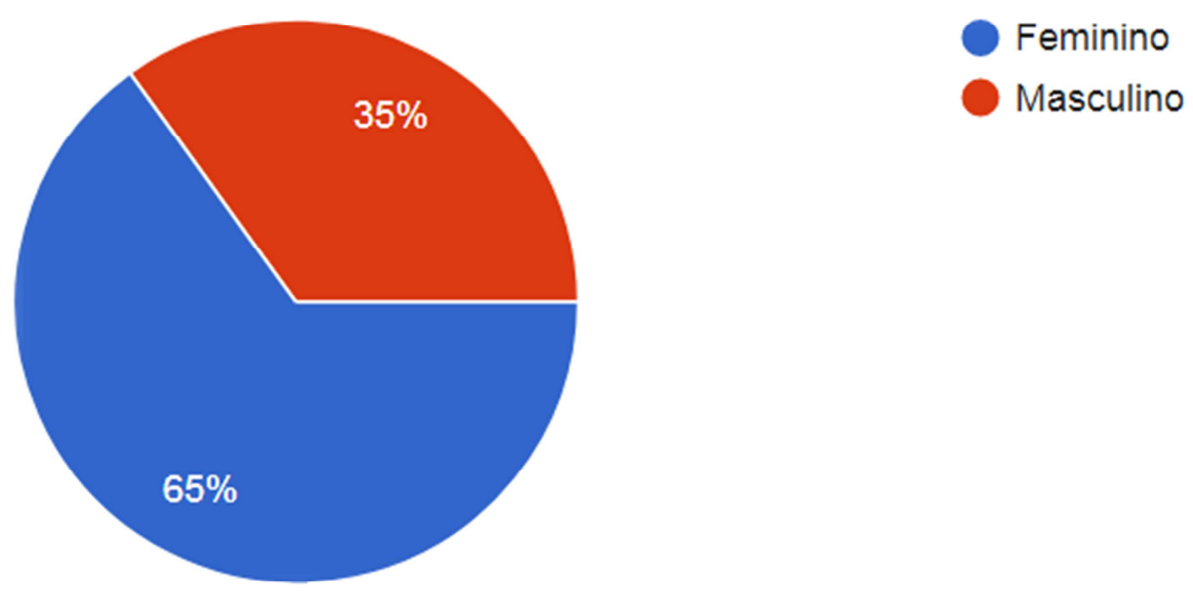

Fonte: (BAIA, J. D., 2018).

A maior parte dos respondentes atua profissionalmente no estado de São Paulo, representando $85 \%$ do total de avaliadores do material desenvolvido (Tabela 1). 
Tabela 1 - Dados referentes aos estados brasileiros de atuação profissional dos respondentes do questionário de avaliação da cartilha educativa - FMVZ - São Paulo - 2018

\begin{tabular}{|c|c|c|c|}
\hline Região do Brasil & Unidade Federativa & Valor absoluto & Porcentagem \\
\hline \multirow{7}{*}{ Norte } & Acre & & \\
\hline & Amapá & & \\
\hline & Amazonas & & \\
\hline & Pará & 1 & $5 \%$ \\
\hline & Rondônia & & \\
\hline & Roraima & & \\
\hline & Tocantins & & \\
\hline \multirow[t]{9}{*}{ Nordeste } & Alagoas & & \\
\hline & Bahia & & \\
\hline & Ceará & & \\
\hline & Maranhão & & \\
\hline & Paraíba & & \\
\hline & Pernambuco & & \\
\hline & Piauí & & \\
\hline & Rio Grande do Norte & & \\
\hline & Sergipe & & \\
\hline \multirow[t]{4}{*}{ Centro-oeste } & Distrito Federal & & \\
\hline & Goiás & & \\
\hline & Mato Grosso & & \\
\hline & Mato Grosso do Sul & 1 & $5 \%$ \\
\hline \multirow[t]{4}{*}{ Sudeste } & Espírito Santo & & \\
\hline & Minas Gerais & & \\
\hline & Rio de Janeiro & & \\
\hline & São Paulo & 17 & $85 \%$ \\
\hline \multirow[t]{3}{*}{ Sul } & Paraná & & \\
\hline & Rio Grande do Sul & 1 & $5 \%$ \\
\hline & Santa Catarina & & \\
\hline
\end{tabular}

Fonte: (BAIA, J. D., 2018).

\subsubsection{Avaliação do conteúdo da cartilha educativa}

Não houve discordância em relação ao conteúdo que compõe a cartilha (Tabela 2). O nível de concordância, porém, não foi unânime em todos os quesitos. 
Tabela 2 - Nível de concordância das afirmações referentes ao conteúdo que compõe a cartilha educativa FMVZ - São Paulo - 2018

\begin{tabular}{|c|c|c|c|c|c|}
\hline \multirow[t]{2}{*}{ Afirmações } & \multicolumn{5}{|c|}{ Nível de concordância } \\
\hline & 1 & 2 & 3 & 4 & 5 \\
\hline $\begin{array}{l}\text { O material aborda o tema "doença periodontal" de maneira } \\
\text { relevante. }\end{array}$ & 20 & 0 & 0 & 0 & 0 \\
\hline $\begin{array}{l}\text { O material traz esclarecimentos a respeito da importância } \\
\text { do correto diagnóstico da doença periodontal. }\end{array}$ & 20 & 0 & 0 & 0 & 0 \\
\hline $\begin{array}{l}\text { O material traz esclarecimentos a respeito da importância } \\
\text { do correto tratamento da doença periodontal. }\end{array}$ & 20 & 0 & 0 & 0 & 0 \\
\hline $\begin{array}{l}\text { O material traz esclarecimentos a respeito dos efeitos } \\
\text { sistêmicos da doença periodontal em cães e gatos. }\end{array}$ & 16 & 4 & 0 & 0 & 0 \\
\hline $\begin{array}{l}\text { O material alerta a respeito dos riscos das lesões } \\
\text { iatrogênicas e suas possíveis consequências legais. }\end{array}$ & 19 & 1 & 0 & 0 & 0 \\
\hline $\begin{array}{l}\text { O material traz esclarecimentos a respeito de erros } \\
\text { conceituais comuns na prática odontológica veterinária. }\end{array}$ & 20 & 0 & 0 & 0 & 0 \\
\hline $\begin{array}{l}\text { O material apresenta suas informações de maneira clara e } \\
\text { objetiva. }\end{array}$ & 19 & 1 & 0 & 0 & 0 \\
\hline $\begin{array}{l}\text { O material pode ser considerado relevante para o público- } \\
\text { alvo que se destina. }\end{array}$ & 20 & 0 & 0 & 0 & 0 \\
\hline $\begin{array}{l}\text { O material estimula o interesse do leitor a respeito da } \\
\text { doença periodontal em cães e gatos. }\end{array}$ & 20 & 0 & 0 & 0 & 0 \\
\hline $\begin{array}{l}\text { O material permite a aplicação de seu conteúdo na prática } \\
\text { profissional do Médico Veterinário. }\end{array}$ & 20 & 0 & 0 & 0 & 0 \\
\hline
\end{tabular}

Fonte: (BAIA, J. D.; 2018).

Legenda: Nível de concordância 1: concordo totalmente; Nível de concordância 2: concordo parcialmente; Nível de concordância 3: indiferente; Nível de concordância 4: discordo parcialmente; Nível de concordância 5: discordo totalmente. Os níveis de concordância referem-se às opções de resposta de acordo com a teoria de Rensis Likert (1932).

Dos respondentes, $80 \%$ concordaram totalmente e $20 \%$ concordaram parcialmente com a afirmação "o material traz esclarecimentos a respeito dos efeitos sistêmicos da doença periodontal em cães e gatos" (Gráfico 3). 
Gráfico 3 - Dados referentes aos esclarecimentos sobre os efeitos sistêmicos da doença periodontal em cães e gatos, obtidos a partir do questionário de avaliação da cartilha educativa - FMVZ - São Paulo - 2018

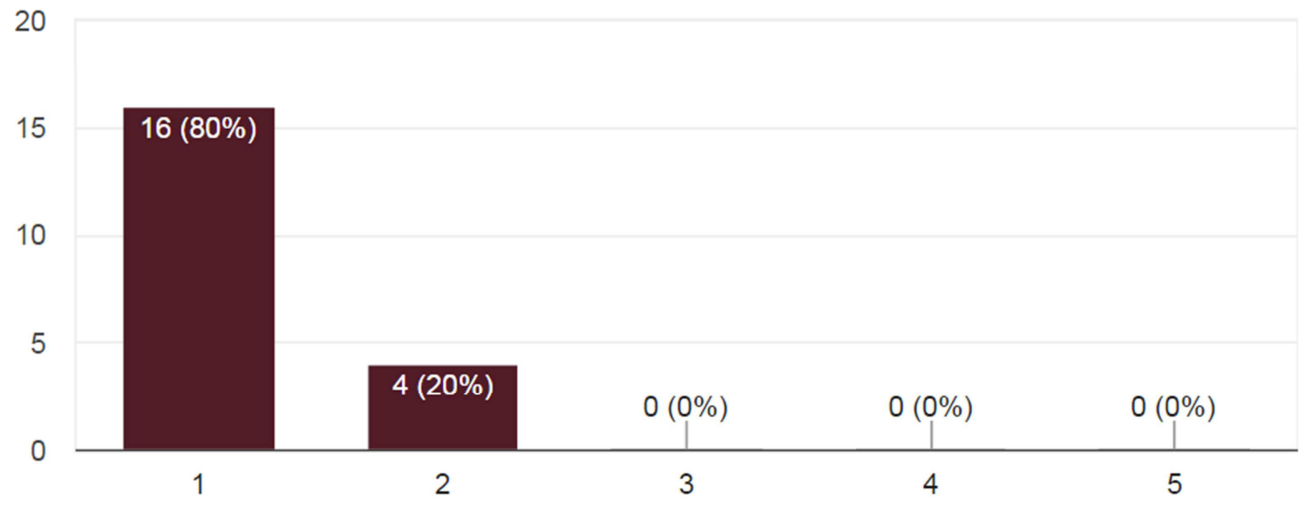

Fonte: (BAIA, J. D.; 2018).

Legenda: 1: concordo totalmente; 2: concordo parcialmente; 3 : indiferente; 4: discordo parcialmente; 5 : discordo totalmente. Os níveis de concordância referem-se às opções de resposta de acordo com a teoria de Rensis Likert (1932).

Houve $95 \%$ de concordância total e $5 \%$ de concordância parcial nas afirmações "o material alerta a respeito dos riscos das lesões iatrogênicas e suas possíveis consequências legais" (Gráfico 4) e "o material apresenta suas informações de maneira clara e objetiva" (Gráfico 5);

Gráfico 4 - Dados referentes aos esclarecimentos sobre os riscos das lesões iatrogênicas e possíveis consequências legais, obtidos a partir do questionário de avaliação da cartilha educativa - FMVZ - São Paulo 2018

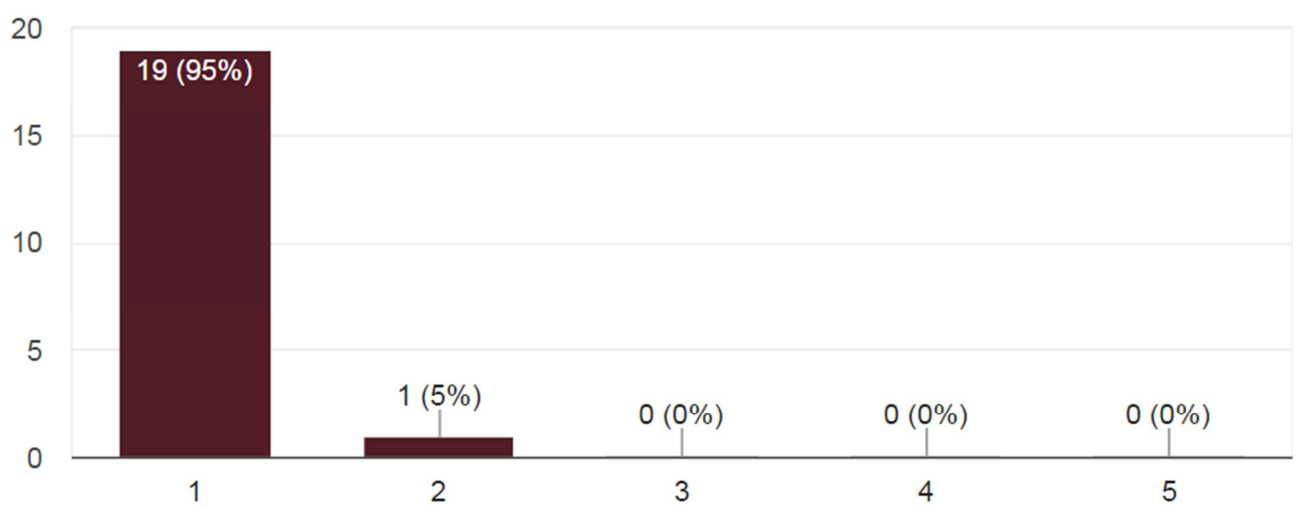

Fonte: (BAIA, J. D.; 2018).

Legenda: 1: concordo totalmente; 2: concordo parcialmente; 3 : indiferente; 4: discordo parcialmente; 5: discordo totalmente. Os níveis de concordância referem-se às opções de resposta de acordo com a teoria de Rensis Likert (1932). 
Gráfico 5 - Dados referentes à apresentação clara e objetiva das informações contidas no material, obtidos a partir do questionário de avaliação da cartilha educativa - FMVZ - São Paulo - 2018

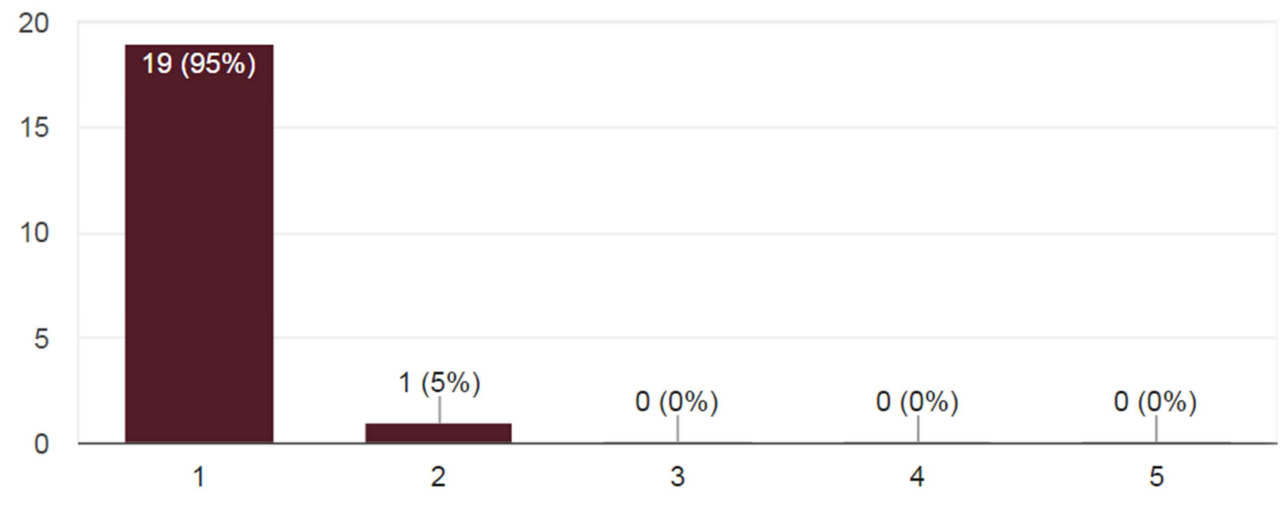

Fonte: (BAIA, J. D.; 2018).

Legenda: 1: concordo totalmente; 2: concordo parcialmente; 3: indiferente; 4: discordo parcialmente; 5: discordo totalmente. Os níveis de concordância referem-se às opções de resposta de acordo com a teoria de Rensis Likert (1932).

\subsubsection{Avaliação dos aspectos visuais e considerações finais}

Houve $100 \%$ de concordância total sobre os aspectos visuais da cartilha (Tabela 3). Igualmente, todos os respondentes concordaram totalmente a respeito da importância da utilização da cartilha educativa como método complementar para o ensino da doença periodontal em cães e gatos (Gráfico 6) e caracterizaram como precária a atual abordagem sobre este tema nos cursos de graduação de medicina veterinária (Gráfico 7). 
Tabela 3 - Respostas referentes aos aspectos visuais do material, obtidos a partir do questionário de avaliação da cartilha educativa - FMVZ - São Paulo - 2018

\begin{tabular}{|c|c|c|c|c|c|}
\hline \multirow[t]{2}{*}{ Afirmações } & \multicolumn{5}{|c|}{ Nível de concordância } \\
\hline & 1 & 2 & 3 & 4 & 5 \\
\hline A quantidade de páginas pode ser considerada adequada. & 20 & 0 & 0 & 0 & 0 \\
\hline As ilustrações podem ser consideradas adequadas. & 20 & 0 & 0 & 0 & 0 \\
\hline O material apresenta um aspecto visual adequado. & 20 & 0 & 0 & 0 & 0 \\
\hline O tamanho dos títulos, tópicos e textos estão adequados. & 20 & 0 & 0 & 0 & 0 \\
\hline As cores utilizadas estão adequadas. & 20 & 0 & 0 & 0 & 0 \\
\hline A fonte escolhida está adequada. & 20 & 0 & 0 & 0 & 0 \\
\hline
\end{tabular}

Fonte: (BAIA, J. D.; 2018).

Legenda: Nível de concordância 1: concordo totalmente; Nível de concordância 2: concordo parcialmente; Nível de concordância 3: indiferente; Nível de concordância 4: discordo parcialmente; Nível de concordância 5: discordo totalmente. Os níveis de concordância referem-se às opções de resposta de acordo com a teoria de Rensis Likert (1932).

Gráfico 6 - Dados referentes a opinião dos respondentes sobre o papel das cartilhas educativas utilizadas como ferramentas complementares ao ensino da doença periodontal em cães e gatos - FMVZ - São Paulo - 2018

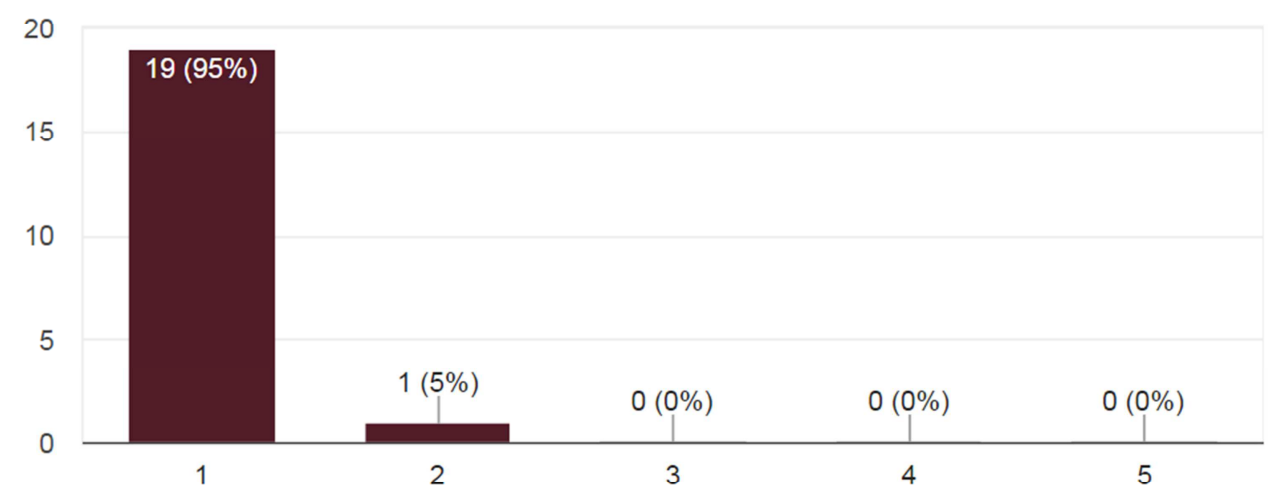

Fonte: (BAIA, J. D.; 2018).

Legenda: 1: concordo totalmente; 2: concordo parcialmente; 3: indiferente; 4: discordo parcialmente; 5: discordo totalmente. Os níveis de concordância referem-se às opções de resposta de acordo com a teoria de Rensis Likert (1932). 
Gráfico 7 - Dados referentes à opinião dos respondentes sobre o ensino da doença periodontal em cães e gatos na graduação de medicina veterinária - FMVZ - São Paulo - 2018

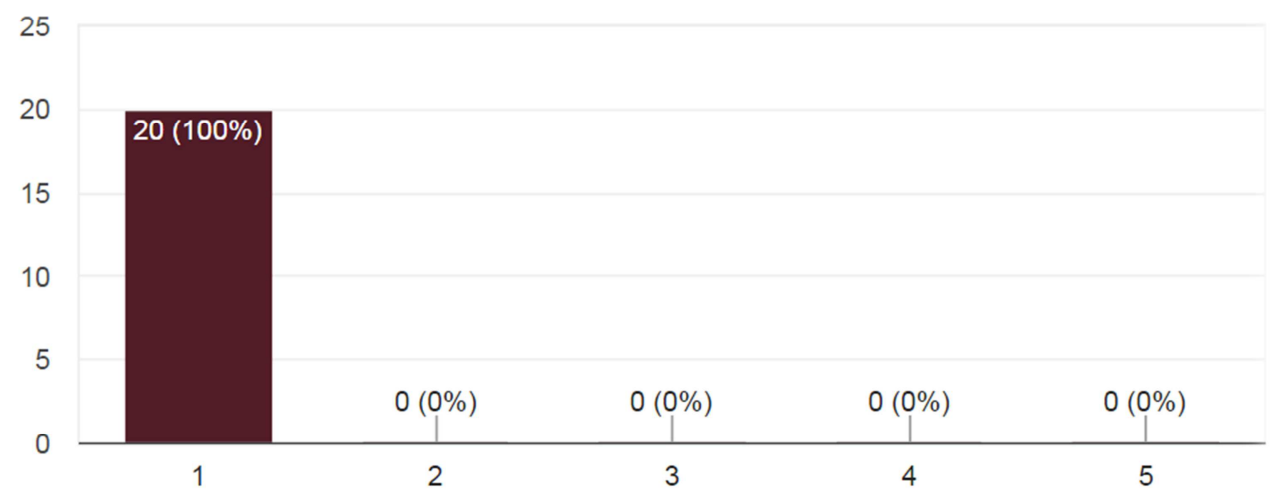

Fonte: (BAIA, J. D.; 2018).

Legenda: 1: concordo totalmente; 2: concordo parcialmente; 3 : indiferente; 4: discordo parcialmente; 5 : discordo totalmente. Os níveis de concordância referem-se às opções de resposta de acordo com a teoria de Rensis Likert (1932). 


\section{DISCUSSÃO}

O processo ensino-aprendizagem é constantemente modificado conforme a evolução da tecnologia é percebida. Atualmente, a demanda educativa não é mais de exclusividade dos alunos de graduação e, a partir da grande competitividade no âmbito profissional, o médico veterinário necessita estar continuamente atualizado. Logo, este profissional espera encontrar informações de fácil e rápido acesso, sendo propício o formato digital em um material de educação complementar (PEREIRA; SCHMITT; DIAS, 2007), sendo esta a razão do formato escolhido para a cartilha desenvolvida neste projeto.

Diversas teorias de autores importantes na área da educação serviram como norteadores para o desenvolvimento desta cartilha educativa (AUSUBEL, 1962; BRUNER, 1960; FREIRE, 1992; PIAGET, 1973; TEIXEIRA, 1957). Utilizaram-se preceitos que visam a compreensão dos conhecimentos propostos no material, através de associações com aprendizados previamente adquiridos na vida acadêmica e na experiência clínica do médico veterinário, além da importância da realidade social do profissional para o desenvolvimento de suas capacidades intelectuais, pois a demanda clínica deste aprendiz, aliada às expectativas de seus clientes, conseguem influenciar diretamente o processo de aprendizagem.

A educação deve ser capaz de desencadear uma visão de interdependência e transdisciplinaridade, sendo um grande desafio para o educador desenvolver a autonomia individual, relacionando-a intimamente ao coletivo (MITRE et al., 2008). Assim sendo, a educação exige constante atualização devido ao rápido desenvolvimento de novas tecnologias que oferecem informação e apresentam grande influência na área da saúde (SHORT, 2002), fato que demonstra a necessidade de manter materiais educativos constantemente atualizados (ECHER, 2005).

Este estudo, ao propor o desenvolvimento e a validação de uma cartilha educativa, pretende que estas orientações sirvam de apoio não apenas ao públicoalvo desta pesquisa - médicos veterinários não especializados, porém atuantes em odontologia veterinária - mas aos estudantes de medicina veterinária e aos docentes que apresentam interesse em compartilhar estas informações, visto que este tema, tão importante para a atuação de um médico veterinário de pequenos 
animais, é pouco presente durante a formação acadêmica (FAULKNER; GUSTAFSON, 1973; KESEL, 2000).

Durante o processo de elaboração de uma cartilha, o pesquisador é desafiado a conseguir transformar suas ideias em um projeto de contexto educativo para seu público-alvo. Estes materiais devem proporcionar em sua formatação diversas estratégias que facilitem a interação do conteúdo com o público leitor, de forma a contribuir para a aquisição de conhecimento (MACHADO, 2015). A fim de alcançar este objetivo, a cartilha educativa desenvolvida neste projeto apresenta diversas ferramentas que visam estimular o interesse do leitor pelo conteúdo e também por sua forma, como por exemplo, a utilização de organizadores gráficos no desenvolvimento do conteúdo, somados a utilização de imagens conceituais e cores específicas na diagramação, estimulando o aprendizado (HANADA, 2017; HEMPHILL, 1996; PIAGET, 1973; PIAGET, 1976; URAL; AKBAY; ALTAY, 2017; WRIGHT; RAINWATER, 1962).

O organizador gráfico é uma importante ferramenta para desenvolvimento deste material, pois consiste em uma representação visual do conhecimento com a utilização de esquemas que resgatam importantes aspectos de um conceito específico a partir do uso de palavras-chave relacionadas entre si. Também chamados de mapa semântico, mapa mental, mapa conceitual, organizador visual, quadro de fluxo, etc., esta ferramenta é parte integrante do modelo construtivista de Piaget $(1973,1976)$, sendo útil no processo ensino-aprendizagem principalmente por sua capacidade de estimular o desenvolvimento de habilidades como o pensamento crítico, compreensão, memória, interação com o tema, construção de conhecimento, capacidade de sintetizar, classificar e categorizar conteúdos.

Oferecendo como objetivo geral uma proposta de educação complementar a respeito da doença periodontal em cães e gatos em formato de cartilha digital, a viabilidade deste projeto deu-se a partir de todas as etapas propostas que foram cuidadosamente planejadas e executadas.

Diversos aspectos facilitaram o desenvolvimento desta pesquisa, desde 0 conhecimento prévio do pesquisador a respeito do tema, a disponibilidade e prontidão do diagramador para o desenvolvimento do material, a colaboração dos avaliadores, a escolha das imagens utilizadas para ilustrar o material, que possibilitaram maior acessibilidade ao público alvo, além do desejo pessoal do 
pesquisador em contribuir com a promoção da saúde oral dos cães e gatos a partir do uso de uma ferramenta de educação complementar.

Pela utilização de um questionário sugerido por Echer (2005), buscou-se validar a cartilha educativa desenvolvida a partir de aspectos citados por Lopes (2009), ao analisar as informações obtidas e interpretá-las nesta discussão de acordo com Bordalo (2006), Polit e Beck (2011), e Vieira (2009).

Utilizou-se a escala proposta por Likert (1932) para graduação e quantificação das respostas obtidas, de acordo com sugestões de Echer (2005). Esta ferramenta mostrou-se satisfatória para a observação e comparação dos dados obtidos.

Esta etapa deu-se por meio da criação de questionários. A formulação das questões obedeceu ao princípio de necessidade, ou seja, seus resultados são diretamente interessantes ao problema da pesquisa (CHAGAS, 2000; VIEIRA, 2009). Cada questionário foi elaborado a partir da transformação da informação desejada em um conjunto de perguntas, de modo a minimizar os erros nas respostas, garantindo a padronização e comparação de dados obtidos para aumentar a velocidade e precisão dos registros, facilitando o processamento dos dados (GÜNTHER, 2003; VIEIRA, 2009).

Mesmo havendo aplicação de questionários, não houve necessidade em submeter este projeto à Comissão Nacional de Ética em Pesquisa (CONEP) visto que apresenta, como características, fatores excludentes para submissão como, por exemplo, a utilização de dados previamente disponíveis ao acesso público e irrestrito, além de solicitar informações com o objetivo de monitorar um serviço para fins de sua melhoria ou implementação (BRASIL, 2012).

$\mathrm{Na}$ elaboração de um questionário, a definição de escalas ou alternativas adequadas de respostas deve ser feita com muito zelo. Após a formulação das questões integrantes deste instrumento de coleta de dados, foi preciso decidir quantos níveis de escala seriam considerados para a obtenção das informações do público-alvo (VIEIRA, 2009). Definiu-se então o uso de uma escala de cinco pontos: "concordo totalmente", "concordo parcialmente", "indiferente", "discordo parcialmente" e "discordo totalmente", sob a justificativa de conseguir extrair informações claras do respondente. Um requisito básico para definir uma escala adequada é o equilíbrio entre as respostas positivas e negativas, apresentando uma categoria neutra que garante uma análise não tendenciosa dos dados (AGUIAR; SOARES, 2012; GÜNTHER; JÚNIOR, 2012; LIKERT, 1932; MCCLELLAND, 1976; 
VIEIRA, 2009). Bastante utilizada em pesquisas sociais, a escala de respostas psicométricas de Rensis Likert (1932) é capaz de mensurar a intensidade de opiniões e atitudes do respondente a partir de uma série graduada de itens dentre os quais o indivíduo deve assinalar apenas uma das opções que melhor correspondem à sua percepção sobre o fato inquirido.

A escolha do método transversal para a coleta dos dados deu-se pelo período específico de tempo em que a mesma ocorreu, correspondendo ao objetivo de responder uma questão que ocorre em um determinado momento. Além disso, classificou-se a coleta de dados como quantitativa e generalizável, já que o objetivo era classificar, ordenar e mensurar as variáveis obtidas através de questionário (BORDALO, 2006; VIEIRA, 2009).

Profissionais especializados no tema abordado pelo material educativo são importantes personagens para a sua validação (ECHER, 2005; FEHRING, 1987). Nesta etapa do projeto, o autor deve estar aberto a críticas para que as expectativas e necessidades do público-alvo consigam ser atendidas a partir das contribuições feitas pelos profissionais em questão (ECHER, 2005).

Seguindo o referencial metodológico de Echer (2005), a última etapa da construção de materiais de educação na área da saúde propõe que ele seja validado. Validar, dentre outras significações, quer dizer tornar legítimo (FERREIRA, 2014). Antes da disponibilização desta ferramenta de atuação profissional é necessário testá-la a fim de se conhecer sua efetividade (AGUIAR, 2010). Há muitos anos, tem-se observado a elaboração de tecnologias na área da saúde que se tornaram reconhecidas e utilizadas após o seu processo de validação (MOURA et al., 2008). Logo, submeter um instrumento ao processo de validação antes da sua utilização é fundamental, uma vez que isso proporciona a verificação da qualidade dos dados (BOAVENTURA, 2004).

Não havendo concordância por parte dos autores em determinar 0 número de avaliadores para a validação de materiais de educação complementar na área de saúde (BOJÖ et al., 2004; CRUZ, 2015; OLIVEIRA; FERNANDES; SAWADA, 2008; OLIVEIRA; LOPES; FERNANDES, 2014; PEREIRA, 2014; RUBIO et al., 2003), propôs-se neste trabalho utilizar um número igual a 20 participantes.

Os resultados foram obtidos a partir de 20 respondentes pós-graduados em odontologia veterinária. De acordo com Ferro (2012), o aumento de cursos de pós-graduação na medicina veterinária consolida-se como forma de qualificação 
para profissionais que buscam oferecer serviço especializado e, desta forma, percebe-se uma transição entre modelos profissionais. $O$ antigo modelo generalista é gradativamente substituído por profissionais que procuram conhecimentos específicos e exclusivos, de maneira aprofundada, que objetivam oferecer serviço de qualidade altamente especializado (CÔRTES, 2006; KUHN, 1998). Assim, a cartilha educativa desenvolvida neste projeto apresenta-se como ferramenta útil para complementar o estabelecimento de novos paradigmas.

A partir de mudanças que dizem respeito aos padrões demográficos e de moradia das sociedades contemporâneas, como a redução da quantidade de integrantes nas famílias e o aumento das habitações verticalizadas, percebe-se também uma alteração significativa no comportamento das famílias em relação aos seus animais de estimação (PESSANHA; PORTILHO, 2008).

A antropomorfização sentimental, descrita por KONECKI (2007), discute a crescente preocupação ética em relação ao tratamento dado a estes animais, que reflete em um relacionamento cada vez mais humanizado. Este fenômeno provoca grande dinamismo no mercado de cuidados veterinários (NOGUEIRA JR.; NOGUEIRA, 2009), sendo a preocupação com a saúde e bem-estar dos animais de estimação percebida também pela economia. Existe um crescente aumento na demanda de serviços veterinários especializados na área da saúde, estimulados principalmente pelo desejo do proprietário em prolongar e melhorar a vida de seu animal de estimação (CAVANAUGH; LEONARD; SCAMMON, 2008).

Acredita-se que, além de experiência profissional a partir da vivência hospitalar, o médico veterinário deve buscar adquirir conhecimentos em cursos de pós-graduação, no intuito de proporcionar maior qualidade em seu atendimento. Para tal, faz-se necessário haver comprometimento profissional com anos extras de estudo além da graduação. Consequentemente, profissionais mais capacitados tendem a ter mais idade (FAULKNER; GUSTAFSON, 1973). Este estudo apresentou, assim como em Pereira (2014), mais respondentes com faixa etária entre 31 e 40 anos, dado que constata um perfil de maior experiência e amadurecimento profissional, com aumento de produtividade econômica e social.

Corroborando resultados de Ferro (2012), em sua maioria os respondentes deste estudo, além do sexo feminino, eram atuantes profissionalmente no estado de São Paulo. 
O estado de São Paulo lidera o crescimento do mercado pet no país, que mesmo durante a crise de 2016 aumentou em quase 5\% seu faturamento, atingindo mais de 18 bilhões de reais. Dentre inúmeros fatores, isto também é resultado da mudança no comportamento de proprietários de animais de estimação, que os consideram membros da família, buscando proporcioná-los maior bem-estar e conforto (TRINDADE, 2018). Percebe-se que, deste modo, serviços especializados encontram bastante espaço nesta região do país.

O interesse pela competência especializada cresce continuamente na profissão (NIELSEN, 2001). Aliado hoje ao estímulo do mercado, há décadas discute-se a necessidade e importância da especialização na medicina veterinária, principalmente pela falta de equilíbrio na relação entre tempo de graduação e disciplinas ofertadas, pois muitas vezes assuntos importantes são brevemente discutidos ou sequer mencionados como, por exemplo, a saúde oral dos animais (FAULKNER; GUSTAFSON, 1973; KESEL, 2000), um componente essencial para o estabelecimento da saúde sistêmica e consequente aumento da qualidade de vida dos animais domésticos (HOLMSTROM et al., 2013; PAVLICA et al., 2008).

Todos os respondentes concordaram totalmente com a importância do ensino da doença periodontal em cães e gatos durante a graduação em medicina veterinária. De acordo com Perry (2014), embora a doença periodontal seja muito comum em pequenos animais, odontologia veterinária ainda é um assunto amplamente ignorado nos currículos da maioria das universidades em todo 0 mundo. Desta maneira, a lacuna no ensino desta temática, sua importância para a saúde dos animais e seu impacto na economia, tornam-se uma tríade que justifica a escolha do tema e também do público-alvo do material desenvolvido neste projeto.

Os tópicos que não apresentaram 100\% de concordância total foram, de fato, pouco discutidos na cartilha desenvolvida neste projeto. A escolha da abordagem superficial para os temas de maior complexidade fundamenta-se em Echer (2005). A autora afirma que materiais educativos desenvolvidos na área da saúde devem prezar por um padrão simplificado em sua linguagem, no intuito de evitar o distanciamento entre o material e seu público de destino. Devido ao nível de complexidade em ambos os tópicos, fez-se imprescindível a utilização de recursos da transposição didática sugeridos por Chevallard (1998). Para $20 \%$ dos respondentes, houve concordância parcial a respeito dos esclarecimentos que a cartilha traz sobre efeitos sistêmicos da doença periodontal em cães e gatos. Houve 
$5 \%$ de concordância parcial a respeito dos esclarecimentos que a cartilha traz sobre os riscos das lesões iatrogênicas e suas possíveis consequências legais.

São inúmeros os fatores que favorecem a ocorrência do erro médico, destacando-se o perfil do profissional, sua relação com o paciente, suas condições de trabalho, sua formação acadêmica e também sua percepção do conceito da ética. Na medicina veterinária, regras e protocolos assumem o papel mais importante na rotina clínica, não permitindo espaço para a valorização da ética. A educação apresenta-se, então, como baluarte para a compreensão e identificação do erro médico. Sugere-se que tanto a educação ética quanto técnica seja discutida durante a graduação, tornando a educação ética uma possível estratégia em prol da redução dos processos éticos e civis (BROCKETT et al., 1997; MAGALHÃES-SANT'ANA, 2016; PELLEGRINO; MCELHINNEY, 1982; SLOWINSKI et al., 2016; TAVARES, 2007).

Diante da crescente ocorrência de erro médico relacionado à doença periodontal em cães e gatos, torna-se de extrema importância facilitar a disponibilização de informações a respeito deste tema, por meio da comunicação em saúde, com o intuito de minimizar os erros comuns e tornar o profissional mais seguro e preparado para o correto diagnóstico e eleição de tratamentos para este problema de saúde animal de origem oral (NIEMIEC et al., 2018). Pouco discutida na medicina veterinária, a comunicação em saúde é uma estratégia amplamente utilizada nas profissões relacionadas à saúde. Ela se define como um conjunto de ações e ferramentas com a finalidade de informar, influenciar percepções e decisões, discutir problemas, desmistificar conceitos e estimular alterações de comportamento (MACHADO et al., 2007; MOREIRA; NÓBREGA; SILVA, 2003).

A eficácia desta estratégia, porém, depende do complexo processo ensinoaprendizagem. É senso comum entre os educadores que o desinteresse dos alunos seja um dos grandes problemas que interferem diretamente neste processo. Deste modo, é necessário que o conjunto de informações novas seja intrinsecamente desejável para que o aluno queira aprender. Sendo assim, torna-se dever do educador levar o educando a querer aprender, pois aquele deve buscar auxílio nas mais diversas teorias pedagógicas, no intuito de compreender o processo educativo e ser capaz de estimular neste o tão esperado aprendizado (PARO, 2016; SILVA; NAVARRO, 2012). 
Percebe-se que o processo ensino-aprendizagem tem se restringido, muitas vezes, apenas à reprodução de conhecimento, em que o docente torna-se transmissor de conteúdos e o discente repete-os (MITRE et al., 2008). desenvolvimento desta cartilha buscou ir além, propondo que esta seja uma ferramenta utilizada pelo aprendiz com o objetivo de gerar empenho e comprometimento com o aprendizado por ela proposto.

Assim como afirmam Sobral e Campos (2012), este material serviu como um complemento ao ato de ensinar, influenciando o ganho de habilidades cognitivas. Existiu, a partir do uso desta cartilha, a aproximação crítica do educando com a realidade, sob a perspectiva de refletir a respeito de problemas que geram curiosidade, desafio e são parte de seu cotidiano.

A concordância total apresentada em 100\% das afirmações referentes a relevância da discussão sobre o tema abordado pela cartilha educativa pode ser justificada por Mcfadden e Marretta (2013), e Fernandes et al. (2012). Estes autores afirmam que, além do desconhecimento por parte dos médicos veterinários, grande parte dos proprietários não está ciente desta afecção, sendo eles incapazes de reconhecer seus sinais clínicos, permitindo que a doença periodontal seja frequentemente deixada sem tratamento até que ocorram consequências severas.

Sendo especializados na temática em questão e compreendendo sua relevância, todos os 20 respondentes concordaram totalmente com os esclarecimentos sobre a importância do correto diagnóstico e tratamento da doença periodontal. Ademais, as informações contidas no material foram extraídas de fontes científicas altamente confiáveis. A doença periodontal é a afecção mais significativa da cavidade oral, com prevalência superior a $70 \%$ nos cães e gatos adultos. De fato, esta é a doença de maior acometimento nestes animais, apesar de poder ser completamente prevenida através de cuidados odontológicos específicos e diários, somados ao acompanhamento de um médico veterinário especializado em odontologia veterinária (AVDC, 2018a; CLARKE; CAMERON, 1998; HARVEY, 1998; HOLMSTROM et al., 2013; MARSHALL et al., 2014; THENGCHAISRI et al., 2017). 


\section{CONSIDERAÇÕES FINAIS}

A insuficiência de materiais educativos a respeito do tratamento periodontal em cães e gatos para serem utilizados como modelos, além da dificuldade em acessar dados referentes aos processos éticos e civis relacionados ao tema, foram alguns aspectos que dificultaram a elaboração deste trabalho.

A revisão não sistemática foi considerada suficiente para o embasamento da construção da cartilha e o questionário criado foi uma importante ferramenta para sua avaliação por veterinários especializados, sendo este instrumento considerado efetivo para validação.

Verificou-se pela validação do material, que a cartilha educativa é uma importante ferramenta complementar para o ensino da doença periodontal.

Conclui-se que as informações sobre as lesões iatrogênicas causadas no tratamento periodontal foram elucidadas pela cartilha, contribuindo para a ética profissional na odontologia veterinária.

Após a validação positiva da cartilha educativa em todos os aspectos avaliados por profissionais especializados na temática, conclui-se que a ampla distribuição deste material poderá auxiliar, de forma elucidativa, a respeito das características da doença periodontal, seus efeitos sistêmicos e o tratamento ideal a ser considerado em cada fase da doença, evitando-se lesões iatrogênicas e possíveis problemas legais.

A partir da compreensão dada por este estudo, os médicos veterinários tem a possibilidade de repensarem sua prática profissional no que diz respeito ao comportamento atual que apresentam em relação ao diagnóstico e tratamento da doença periodontal em cães e gatos. Além disto, conclui-se que este material pode ser utilizado para estimular o interesse dos médicos veterinários a respeito da temática, sendo também um instrumento complementar para o ensino durante a graduação em medicina veterinária.

Sendo assim, sugere-se uma discussão que proponha revisão curricular, possibilitando a introdução da odontologia veterinária no currículo de formação de médicos veterinários. Ademais, sugere-se que sejam desenvolvidos materiais educativos digitais em diversas áreas da medicina veterinária, visto que estas ferramentas complementares trazem benefícios para a formação profissional. 
Por fim, pode-se concluir que estudos elaborados com abordagens que possibilitam a criação de materiais educativos complementares contribuem para a prática clínica do médico veterinário. 


\section{REFERÊNCIAS}

ABDUCH, C. Grupos operativos com adolescentes. Cadernos, juventude, saúde e desenvolvimento, v.1. Brasília, DF, agosto, 1999. 303 p.

AGUIAR, A. S. C. Validação de tecnologia para avaliação do teste do reflexo vermelho. 2010. 103 f. Dissertação (Mestrado) - Faculdade de Farmácia, Odontologia e Enfermagem, Universidade Federal do Ceará, Fortaleza, 2010.

AGUIAR, B.; SOARES, N. Proposta de uma escala de autorrelato para a análise de jogos. In: SIMPÓSIO BRASILEIRO DE GAMES E ENTRETENIMENTO DIGITAL, 11., 2012, Brasília. Anais... Brasília: Sociedade Brasileira de Computação, 2012. p. 19-26.

AIMETTI, M. Nonsurgical periodontal treatment. International Journal of Esthetic Dentistry, v. 9, n. 2, 2014.

AKIRA, S.; TAKEDA, K. Toll-like receptor signaling. Nature Reviews Immunology, v.4, p. 499-511, 2004.

AMERICAN VETERINARY DENTAL COLLEGE (AVDC). Risks of anesthesia free pet dental cleanings. In: Anesthesia free dentistry: Know the facts. Disponível em: <http://avdc.org/AFD/reasons-not-to-choose-anethesia-free-pet-dentals/>. Acesso em: 20 mar. 2018a.

AMERICAN VETERINARY DENTAL COLLEGE (AVDC). Furcation involvement and mobility index. In: Nomenclature. Disponível em:

<https://www.avdc.org/Nomenclature/Nomen-Perio.html\#periostages>. Acesso em: 20 mar. 2018b.

AMERICAN VETERINARY DENTAL COLLEGE (AVDC). Stages of periodontal disease. In: Nomenclature. Disponível em:

$<$ https://www.avdc.org/Nomenclature/Nomen-Perio.html\#periostages >. Acesso em: 20 mar. 2018c.

AMERICAN VETERINARY DENTAL COLLEGE (AVDC). The use of antibiotics in veterinary dentistry. In: . AVDC position statements. Disponível em:

<http://avdc.org/statements.html>. Acesso em: 20 mar. 2018d. 
AMERICAN VETERINARY DENTAL COLLEGE (AVDC). What is AVDC?. In: . What is AVDC? Disponível em: < https://www.avdc.org/about.html>.

Acesso em: 20 mar. 2018e.

ARMITAGE, G. C. Development of a classification system for periodontal disease and conditions. Annals of Periodontology, v. 4, n.1, p. 1-6, 1999.

AUSUBEL, D. P. A subsumption theory of meaningful learning and retention. Journal of General Psychology, v. 66, p. 312-224,1962.

BARROS, A. M. Curso de direito do trabalho. 11. ed. São Paulo: LTr, 2017.

BECKMAN, B. Anesthesia and pain management for small animals.

Veterinary Clinics of North America: Small Animal Practice, v. 43, n. 3, p. 669688, 2013.

BICKEL, J. Human values teaching programs in the clinical education of medical students. Academic Medicine, v. 62, n. 5, 1987.

BITENCOURT, A. G. V.; NEVES, N. M. B. C.; NEVES, F. B. C. S.; BRASIL, I. S. P. S.; SANTOS, L. S. C. Análise do erro médico em processos ético-profissionais: Implicações na educação médica. Revista Brasileira de Educação Médica, v. 31 , n. 3, p. 223-228, 2007.

BOAVENTURA, A. P. Registro do atendimento da parada cardiorrespiratória no ambiente intra-hospitalar: Validade e aplicabilidade de um instrumento. 2004. 97 f. Dissertação (Mestrado) - Faculdade de Ciências Médicas, Universidade Estadual de Campinas, Campinas, 2004.

BOJÖ, A. K. S.; HALL-LORD, M. L.; AXELSSON, O.; UDÉN, G.; WILDE, L. B. Midwifery care: development o fan instrument to measure quality base on the World Health Organization"s classification of care in normal birth. Journal of Clinical Nursing, v. 13, p. 75-83, 2004.

BORDALO, A. A. Estudo transversal e/ou longitudinal. Revista Paraense de Medicina, v. 20, 2006.

BORDENAVE, J. D.; PEREIRA, A. M. Estratégias de ensino-aprendizagem. Petrópolis: Vozes, 1998. 
BOUFORD, J. I.; CARSON, R. A. (Project directors). The teaching of humanities and human values in primary care residency training. McLean: Society for Health and Human Values, 1984.

BRASIL. Ministério da Saúde. Conselho Nacional de Saúde. Resolução nº. 466, de 12 de dezembro de 2012. Diretrizes e normas regulamentadoras de pesquisas envolvendo seres humanos. Diário Oficial da União, Brasília, 12 dez. 2012.

BRASIL. Lei no . 8.078, de 11 de setembro de 1990. Código de defesa do consumidor. Diário Oficial da União, Brasília, DF, 12 de novembro de 1990 [Em suplemento].

BROCKETT, M.; GEDDES, E. L.; WESTMORLAND, M.; SALVATORI, P. Moral development or moral decline? A discussion of ethics education for the health care professions. Medical Teacher, v. 19, n. 4, p. 301-309, 1997.

BRUNER, J. The process of education. Cambridge: Harvard University Press, 1960. $92 \mathrm{p}$.

CAIAFA, A. Canine infectious, inflammatory and immune-mediated oral conditions. In: TUTT, C.; DEEPROSE, J.; CROSSLEY, D. A. BSAVA manual of canine and feline dentistry. 3. ed. England: British Small Animal Veterinary Association, 2007. p. 96-125.

CAMARGO, S. L. S.; GIOSO, M. A.; CARVALHO, V. G. G. Dor de dente: Os animais, nossos pacientes, sentem ou não? Revista Científica de Medicina Veterinária - Pequenos Animais e Animais de Estimação, v. 8, n. 24, p. 37-43, 2010.

CARRANZA, F.; NEWMAN, M.; TAKEI, H.; KLOKKEVOLD, P. Carranza's clinical periodontology. 11. ed. Saint Louis: Elsevier Saunders, 2012. 1328 p.

CAVALIERI FILHO, S. Programa de responsabilidade civil. 12. ed. São Paulo: Editora Atlas, 2015.

CAVALIERI FILHO, S. Responsabilidade civil no novo código civil. Revista da Escola de Magistratura do Estado do Rio de Janeiro, v. 6, n. 24, 2003. 
CAVANAUGH, L. A.; LEONARD, H. A.; SCAMMON, D. L. A tail of two personalities: How canine companions shape relationships and well-being. Journal of Business Research, v. 61, n. 5, p. 469-479, 2008.

CHAGAS, A. T. R. O questionário na pesquisa científica. Administração On Line, v. 1, n. 1, 2000.

CHEVALLARD, Y. La transposición didáctica: Del saber sabio al saber enseñado. 3. ed. Buenos Aires: Aique, 1998.

CLARKE, D. E.; CAMERON, A. Relationship between diet, dental calculus and periodontal disease in domestic and feral cats in australia. Australian Veterinary Journal, v. 76, n. 10, p. 690-693, 1998.

CONSELHO FEDERAL DE MEDICINA VETERINÁRIA (CFMV). Resolução no. 1138, de 16 de dezembro de 2016. Código de ética profissional do médico veterinário. Disponível em: < http://portal.cfmv.gov.br/uploads/reso\%201138_2016\%20portal\%20cfmv\%20(3).pdf> . Acessado em 22 mar. 2018.

CÔRTES, P. L. Considerações sobre a evolução da ciência e da comunicação científica. In: POBLACIÓN, D. A.; WITTER, G. P.; SILVA, F. M. Comunicação \& produção científica: contexto, indicadores e avaliação. São Paulo: Angelara, 2006. p. 33-55.

CRUZ, F. O. A. M. Manual de orientações para o paciente com câncer de cabeça e pescoço submetido à radioterapia: um estudo de validação. 2015. $141 \mathrm{f}$.

Dissertação (Mestrado em Enfermagem) - Universidade de Brasília, Brasília, 2015.

DINIZ, M. H. Curso de direito civil brasileiro: Responsabilidade civil. 31. ed. São Paulo: Saraiva, 2017. v. 7.

DELL'ISOLA, A. Treinamento prático em leitura dinâmica. 2. ed. São Paulo: Universo Dos Livros, 2010.

DELL'ISOLA, A. Mentes geniais. São Paulo: Universo Dos Livros, 2012.

DEWEY, J. Democracy and education. New York: McMillan, 1916. 
DUKE, F.; SNYDER, C.; BENTHLEY, E.; DUBIELZIG, R. Ocular trauma originating from within the oral cavity: Clinical relevance and histological findings in 10 cases (2003-2013). Journal of Veterinary Dentistry, v. 31, n. 4, 2014.

ECHER, I. C. Elaboração de manuais de orientação para o cuidado em saúde. Revista Latino-americana de Enfermagem, v. 13, n. 5, p. 754-757, 2005.

FAULKNER, S.; GUSTAFSON, P. Should veterinary students specialize? lowa State University Veterinarian, v. 35, n. 2, 1973.

FEHRING, R. Methods to validate nursing diagnoses. Heart Lung, v. 16, n. 6, p. 625-629, 1987.

FERNANDES, N. A.; BORGES, A. P. B; REIS, E. C. C. R.; SEPÚLVEDA, R. V.; PONTES, K. C. S. Prevalence of periodontal disease in dogs and owners' level of awareness: A prospective clinical trial. Revista Ceres, v. 59, n. 4, 2012.

FERREIRA, A. B. H. Dicionário Aurélio da língua portuguesa. 5. ed. São Paulo: Positivo, 2014. 2272 p.

FERRO, D. G. Informação científica em medicina veterinária: o acesso à informação entre pós-graduandos de cursos lato sensu. 2012. Tese (Doutorado em Clínica Cirúrgica Veterinária) - Faculdade de Medicina Veterinária e Zootecnia, Universidade de São Paulo, São Paulo, 2012.

FREIRE, P. Pedagogia da esperança: Um reencontro com a pedagogia do oprimido, São Paulo: Paz e Terra, 1992.

FREITAS, L. V.; TELES, L. M. R.; LIMA, T. M.; VIEIRA, N. F. C.; BARBOSA, R. C. M.; PINHEIRO, A. K. B.; DAMASCENO, A. K. C. Exame físico no pré-natal: construção e validação de hipermídia educativa para a enfermagem. Acta Paulista de Enfermagem, v. 25, n. 4, p.581-588, 2012.

GELSE, K.; POSCHL, E.; AIGNER, T. Collagens: Structure, function, and biosynthesis. Advanced Drug Delivery Reviews, v. 55, p. 1531-1546, 2003. 
GIORDANI, E. M.; MENDES, A. M. A subjetividade no processo pedagógico das orientações no ensino superior. In: FREITAS, D. S.; GIORDANI, E. M.; CORREA, G. C. (Org.). Ações educativas e estágios curriculares supervisionados. Santa Maria: UFSM, 2007.

GIOSO, M. A.; SHOFER, F.; BARROS, P. S. M.; HARVEY, C. E. Mandible and mandibular first molar tooth measurements in dogs: relationship of radiographic height to body weight. Journal of Veterinary Dentistry, v. 18, n. 2, p. 65-68, 2001.

GONÇALVES, C. R. Direito civil brasileiro: Responsabilidade civil. 12. ed. São Paulo: Saraiva, 2017. v. 4.

GORREL, C. Odontologia em pequenos animais. Rio de Janeiro: Elsevier, 2010. $240 \mathrm{p}$.

GOTTARDI, M. L. A autonomia na aprendizagem em educação a distância: competência a ser desenvolvida pelo aluno. Revista da Associação Brasileira de Educação a Distância, v. 14, 2015.

GUERREIRO, C. E.; APPELBOAM, H.; LOWE, R. C. Successful medical treatment for globe penetration following tooth extraction in a dog. Veterinary Ophthalmology, v. 17, n. 2, p. 146-149, 2014.

GÜNTHER, H. Como elaborar um questionário. Planejamento de Pesquisa nas Ciências Sociais, n. 1, 2003.

GÜNTHER, H.; JÚNIOR, J. L. Perguntas abertas versus perguntas fechadas: uma comparação empírica. Psicologia: Teoria e Pesquisa, v. 6, n. 2, p. 203-213, 2012.

HAGIWARA, M. Processo ético profissional [Editorial]. Boletim da Academia Paulista de Medicina Veterinária, v. 8, n. 2, p. 3, 2017.

HAJISHENGALLIS, G. Complement and periodontitis. Biochemical Pharmacology, v. 80, p. $1992-2001,2010$.

HANS, M.; HANS, V. M. Toll-like receptors and their dual role in periodontitis. Journal of Oral Science, v. 53, p. 263-271, 2011. 
HANADA, M. Correspondence analysis of color-emotion associations. Color Research and Application, p. 1-16, 2017.

HARGREAVES, K.; BERMAN, L. (Ed.). Cohen caminhos da polpa. 11. ed. Rio de Janeiro: Elsevier, 2017. 1105 p.

HARVEY, C. E. Periodontal disease in dogs: Etiopathogenesis, prevalence, and significance. Veterinary Clinics of North America: Small Animal Practice, v. 28, n. 5, p. 1111-1128, 1998.

HEMPHILL, M. A note on adults' color-emotion associations. The Journal of Genetic Psychology, v. 157, n. 3, p. 275-280, 1996.

HOLMSTROM, S. E.; BELLOWS, J.; JURIGA, S.; KNUTSON, K.; NIEMIEC, B. A.; PERRONE, J. 2013 AAHA dental care guidelines for dogs and cats. American Animal Hospital Association, 2013.

KANG, M. H.; LIM, C. Y; PARK, H. M. Nasopharyngeal tooth foreign body in a dog. Journal of Veterinary Dentistry, v. 28, p. 26-29, 2011.

KESEL, M. L. Preface. In: Veterinary dentistry for the small animal technician. 1. ed. lowa: Blackwell, 2000. 280 p.

KONECKI, K. T. Pets of Konrad Lorenz. Theorizing in the social world of pet owners. Qualitative Sociology Review, v. 3, n. 1, p. 110-127, 2007.

KOUKI, M. L.; PAPADIMITRIOU, S. A.; KAZAKOS, G. M.; SAVAS, I.; BITCHAVA, D. Periodontal disease as a potential factor for systemic inflammatory response in the dog. Journal of Veterinary Dentistry, v. 30, p. 26-29, 2013.

KUBO, O. M.; BOTOMÉ, S. P. Ensino-aprendizagem: Uma interação entre dois processos comportamentais. Interação em Psicologia, v. 5, n. 1, 2001.

KUHN, T. S. Estruturas das revoluções científicas. São Paulo: Perspectiva, 1998. $257 \mathrm{p}$.

KURGAN, S.; KANTARCI, A. Molecular basis for immunohistochemical and inflammatory changes during progression of gingivitis to periodontitis.

Periodontology 2000, v. 76, n. 1, p. 51-67, 2017. 
LAVAND'HOMME, P. Transition from acute to chronic pain after surgery. Pain, v. 158, n. 4, p. s50-s54, 2017.

LEBLEU, V. S.; MACDONALD, B.; KALLURI, R. Structure and function of basement membranes. Experimental Biology and Medicine, v. 232, p. 1121-1129, 2007.

LIKERT, R. A technique for the measurement of attitudes. Archives of Psychology, V. 140 , p. $1-55,1932$.

LILJESTRAND, J. M.; PAJU, S.; PIETIÄINEN, M.; BUHLIN, K.; PERSSON, G. R.; NIEMINEN, M. S.; SINISALO, J.; MÄNTYLÄ, P.; PUSSINEN, P. J. Immunologic burden links periodontitis to acute coronary syndrome. Atherosclerosis, v. 268, p. 177-184, 2018.

LINDHE, J.; LANG, N.; KARRING, T. Tratado de periodontia clínica e implantologia oral. 5. ed. Rio de janeiro: Guanabara Koogan, 2010. 1304 p.

LÔBO, F.; MACHADO, R. CFMV solicita ao MEC a suspensão de novos cursos de Medicina Veterinária. In: CONSELHO FEDERAL DE MEDICINA VETERINÁRIA (CFMV). Sala de imprensa. Disponível em:

<http://portal.cfmv.gov.br/noticia/index/id/5424>. Acessado em 22 mar. 2018.

LOBPRISE, H. B. Odontologia em pequenos animais: consulta em $\mathbf{5}$ minutos. Rio de Janeiro: Revinter, 2010. 395 p.

LOPES, E. M. Construção e validação de hipermídia educacional em planejamento familiar : abordagem à anticoncepção. 2009. $141 \mathrm{f}$. Dissertação (Mestrado em Enfermagem) - Universidade Federal do Ceará. Faculdade de Farmácia, Odontologia e Enfermagem, Fortaleza, 2009.

MACHADO, L. S. Manual de elaboração de cartilha para orientação de atividades físicas para a mulher no climatério. 2015. 67 f. Dissertação (Mestrado em Educação) - Pontifícia Universidade Católica de São Paulo, Sorocaba, 2015.

MACHADO, M. F. A. S.; MONTEIRO, E. M. L. M.; QUEIROZ, D. T.; VIEIRA, N. F. C.; BARROSO, M. G. T. Integralidade, formação de saúde, educação em saúde e as propostas do SUS: Uma revisão conceitual. Ciência \& Saúde Coletiva, v. 12, n. 2, p. 335-342. 2007. 
MADEIRA, M. C. Anatomia do dente. 4. ed. São Paulo: Sarvier, 2006. 110 p.

MAGALHÃES-SANT'ANA, M. A theoretical framework for human and veterinary medical ethics education. Advances In Health Sciences Education, v. 21, n. 5, p. 1123-1136, 2016.

MARSHALL, M. D.; WALLIS, C. V.; MILELLA, L.; COLYER, A.; TWEEDIE, A. D.; HARRIS, S. A longitudinal assessment of periodontal disease in 52 miniature schnauzers. Biomed Central Veterinary Research, v. 10, n. 166, 2014.

MCCLELLAND, J. A. G. Técnica de questionário para pesquisa. Revista Brasileira de Física, v. 1, n. 1, p. 93-101, 1976.

MCFADDEN, T.; MARRETTA, S. M. Consequences of untreated periodontal disease in dogs and cats. Journal of Veterinary Dentistry, v. 30, n. 4, p. 266-275, 2013.

MITRE, S. M.; SIQUEIRA-BATISTA, R.; GIRARDI-DE-MENDONÇA, J. M.; MORAISPINTO, N. M.; MEIRELLES, C. A. B.; PINTO-PORTO, C.; MOREIRA, T.; HOFFMANN, M. A. Metodologias ativas de ensino-aprendizagem na formação profissional em saúde: Debates atuais. Ciência e Saúde Coletiva, v. 13, n. 2, p. 2133-44, 2008.

MOORE, D. W.; READENCE, J. E. A quantitative and qualitative review of graphic organizer research. Journal of Educational Research, v. 78, p. 11-17, 1984.

MOREIRA, M. F.; NÓBREGA, M. M. L.; SILVA, M. I. T. Comunicação escrita: Contribuição para a elaboração de material educativo em saúde. Revista Brasileira de Enfermagem, v. 56, n. 2, p. 184-188, 2003.

MOURA, E. R. F.; BEZERRA, C. G.; OLIVEIRA, M. S.; DAMASCENO, M. M. C. Validação de jogo educativo destinado à orientação dietética de portadores de diabetes mellitus. Revista de Atenção Primária à Saúde, v. 11, n. 4, p. 435-443, 2008.

NIELSEN, N. O. Is the veterinary profession losing its way? The Canadian Veterinary Journal, v. 42, n. 6, p. 439-445, 2001. 
NIEMIEC, B. A. Disorders of dental hard tissues in dogs. Today's Veterinary

Practice, v. 4, n. 3, p. 97-103, 2014.

NIEMIEC, B. A.; GAWOR, J.; NEMEC, A.; CLARKE, D.; TUTT, C.; GIOSO, M. A.; STEGALL, P.; CHANDLER, M.; MORGENEGG, G.; JOUPPI, R.; STEWART, K. Global dental guidelines. S.I.: World Small Animal Veterinary Association, s.d. Disponível em: <http://www.wsava.org/WSAVA/media/Documents/Guidelines/DentalGuidleines-for-endorsement_0.pdf>. Acesso em 22 mar. 2018.

NOACK, B.; GENCO, R. J.; TREVISAN, M.; GROSSI, S.; ZAMBON, J. J., DE NARDIN, E. Periodontal infections contribute to elevated systemic $C$-reactive protein level. Journal of Periodontology Online, v. 72, n. 9, p. 1221-1227, 2001.

NOGUEIRA JR, S.; NOGUEIRA, E. A. Alimentos para animais de estimação resistem à crise econômica. Análises e Indicadores do Agronegócio, v. 4, n. 11, p. $1-5,2009$.

NOVAK, M. J. Classification of disease and conditions affecting the periodontium. In: NEWMAN, M. G.; TAKEI, H. H.; CARRANZA, F. A. Carranza's Clinical

Periodontology. 9. ed. Califórnia: W. B.Saunders Company, 2002.

OLIVEIRA, M. S.; FERNANDES, A. F. C.; SAWADA, N. O. Manual educativo para o autocuidado da mulher mastectomizada: Um estudo de validação. Texto \& Contexto Enfermagem, v. 17, p. 115-123, 2008.

OLIVEIRA, S. C.; LOPES, M. V. O; FERNANDES, A. F. C. Construção e validação de cartilha educativa para alimentação saudável durante a gravidez. Revista LatinoAmericana de Enfermagem, v. 22, n. 4, p. 611-620, 2014.

PALADINO, F. V. Vias de transdução de sinal do receptor tipo Toll 4 nas células pancreáticas e seus efeitos na secreção e produção de insulina. 2012. Dissertação (Mestrado em Alergia e Imunopatologia) - Faculdade de Medicina, Universidade de São Paulo, São Paulo, 2012.

PARO, V. H. Administração escolar: introdução crítica. 17. ed. São Paulo: Cortez, 2016. 232 p.

PASQUALI, L. Princípios de elaboração de escalas psicológicas. Revista de Psiquiatria Clínica, v. 25, n. 5, p. 206-213, 1998. 
PAVLICA, Z.; PETELIN, M.; JUNTES, P.; ERZEN, D.; CROSSLEY, D. A.;

SKALERIC, U. Periodontal disease burden and pathological changes in organs of dogs. Journal of veterinary dentistry, v. 25, n. 2, p. 97-105, 2008.

PAZÓ, C. G.; HEANCIO, S. F. Responsabilidade civil do médico veterinário: Uma análise à luz do código de ética do médico veterinário. Revista do Instituto do Direito Brasileiro, n. 3, p. 2129-2156, 2014.

PELLEGRINO, E. D.; MCELHINNEY, T. K. Teaching ethics, the humanities, and human values in medical schools: a ten-year overview. Washington, D. C.: Institute on Human Values in Medicine Society for Health and Human Values, 1982. $101 \mathrm{p}$.

PEREIRA, C. R. Construção e validação de uma cartilha de orientação sobre o tratamento quimioterápico. 2014. 97 f. - Dissertação (Mestrado) - Universidade Federal do Ceará, Programa de Pós-graduação em Políticas Públicas e Gestão da Educação Superior, Fortaleza (CE), 2014.

PEREIRA, A. T. C.; SCHMITT, V.; DIAS, M. R. A C. Ambientes Virtuais de Aprendizagem. In: PEREIRA, A. T. C. (orgs). AVA: Ambientes Virtuais de Aprendizagem em diferentes contextos. Rio de Janeiro: Editora Ciência Moderna Ltda., 2007.

PERRY, R. Final year veterinary students' attitudes towards small animal dentistry: A questionnaire-based survey. Journal of Small Animal Practice, v. 55, n. 9, p. 457464, 2014.

PESSANHA, L.; PORTILHO, F. Comportamentos e padrões de consumo familiar em torno dos "pets". In: ENCONTRO NACIONAL DE ESTUDO DO CONSUMO, 4, 2008, Rio de Janeiro. Anais... Rio de Janeiro: Universidade Federal Fluminense, 2008.

PETERS, J. L.; DEMARS, P. L.; COLLINS, L. M.; STONER, J. A.; MATSUMOTO, H.; KOMORI, N.; SINGH, A.; FEASLEY, C. L.; HADDOCK, J. A.; LEVINE, M. Effects of immunization with natural and recombinant lysine decarboxylase on canine gingivitis development. Vaccine, v. 30, p. 6706-6712, 2012.

PIAGET, J. A epistemologia genética. Rio de Janeiro: Vozes, 1973. 110 p.

PIAGET, J. A equilibração das estruturas cognitivas: problema central do desenvolvimento. Rio de Janeiro: Zahar, 1976. 175 p. 
POLIT, D. F.; BECK, C. T. Fundamentos de pesquisa em enfermagem: avaliação de evidências para a prática da enfermagem. 7. ed. Porto Alegre: Artmed, 2011. 669 p.

REBERTE, L. M.; HOGA, L. A. K.; GOMES, A. L. Z. Process of construction of an educational booklet for health promotion of pregnant women. Revista LatinoAmericana de Enfermagem, v. 20. 2012.

REICHART, P. A.; DURR, U. M.; TRIADAN, H.; VICKENDEY, G. Periodontal disease in the domestic cat. Journal of Periodontal Research, v. 19, p. 67-75, 1984.

REITER, A. M.; BRADY, C. A.; HARVEY, C. E. Local and systemic complications in a cat after poorly performed dental extractions. Journal of Veterinary Dentistry, v. 21, n. 4, p. 215-221. 2004.

RIBEIRO, M. A. S.; VEDOVATO, T. G.; LOPES, M. H. B. M.; MONTEIRO, M. I.; GUIRARDELLO, E. B. Estudos de validação na enfermagem: revisão integrativa. Revista da Rede de Enfermagem do Nordeste, v. 14, p. 218-228, 2013.

ROBINSON, M. J.; COBB, M. H. Mitogen-activated protein kinase pathways. Current Opinion in Cell Biology, v. 9, p.180-186, 1997.

RUBIO, D. M.; BERG-WEGER, M.; TEBB, S. S.; LEE, E. S.; RAUCH, S. Objectifying content validity: conducting a content validity study in social work research. Social Work Research, v. 27, n. 2, p. 94-111, 2003.

SACRISTÁN, J. G.; GÓMEZ, A. I. P. Compreender e transformar o ensino. 4. ed. Porto Alegre: Artmed, 2007.

SAGE PUBLISHING (SAGE). Description. In: Journal of veterinary dentistry. Disponível em: < https://us.sagepub.com/en-us/sam/journal-of-veterinarydentistry/journal202557\#description>. Acesso em: 20 mar. 2018.

SANTANA, M. F.; CARLOS, E. J. Regularidades e dispersões no discurso da aprendizagem significativa em David Ausubel e Paulo Freire. Aprendizagem Significativa em Revista, v. 3, n. 1, p. 12-22, 2013.

SANTOS, S. C. O processo de ensino-aprendizagem e a relação professor-aluno: aplicação dos "sete princípios para a boa prática na educação de ensino superior". Caderno de pesquisas em administração, v. 8, n. 1, p. 69-82, 2001. 
SHORT, N. The use of information and communication technology in veterinary education. Research in Veterinary Science, v. 72, p. 1-6, 2002.

SILVA, O. G.; NAVARRO, E. C. A relação professor-aluno no processo ensinoaprendizagem. Revista Eletrônica da Univar, v. 3, n. 8, p. 95-100, 2012.

SILVA, S. C. R.; SCHIRLO, A. C. teoria da aprendizagem significativa de Ausubel: Reflexões para o ensino de física ante a nova realidade social. Imagens da Educação, v. 4, n. 1, 2014.

SLOWINSKI, K.; TREMORI, T. M.; MASSAD, M. R. R.; TASAKA, A. C.; ROCHA, N. $S$. Responsabilidade ética e civil do médico-veterinário no ambiente hospitalar. Revista de educação continuada em Medicina Veterinária e Zootecnia do CRMV-SP, v. 14, n. 2, p. 30-37, 2016.

SMITH, M. M.; SMITH, E. M.; LA CROIX, N.; MOULD, J. Orbital penetration associated with tooth extraction. Journal of Veterinary Dentistry, v. 20, p. 8-17, 2003.

SOBRAL, F. R.; CAMPOS, C. J. G. Utilização de metodologia ativa no ensino e assistência de enfermagem na produção nacional: Revisão integrativa. Revista da Escola de Enfermagem da USP, v. 46, n. 1, p. 208-218, 2012.

STILES, J.; WEIL, A. B.; PACKER, R. A.; LANTZ, G. C. Post-anesthetic cortical blindness in cats: Twenty cases. The Veterinary Journal, v. 193, n. 2, p. 367-373. 2012.

STEVENS-SPARKS, C. K.; STRAIN, G. M. Post-anesthesia deafness in dogs and cats following dental ande ar cleaning procedures. Veterinary Anaesthesia and Analgesia, v. 37, p. 347-351, 2010.

SULMASY, D. P. Should medical schools be schools for virtue? Journal of General Internal Medicine, v. 15, p. 514-516. 2000.

TAVARES, F. M. Reflexões acerca da iatrogenia e educação médica. Revista Brasileira de Educação Médica, v. 31, n. 2, p. 180-185, 2007. 
TEIXEIRA, A. Ciência e arte de educar. Educação e Ciências Sociais, v. 2, n. 5, p. 5-22, 1957.

TAYLOR, T. N.; SMITH, M. M.; SNYDER, L. Nasal displacement of a tooth root in a dog. Journal of Veterinary Dentistry, v. 21, n. 4, p. 222-225, 2004.

THENGCHAISRI, N.; STEINER, J. M.; SUCHODOLSKI, J. S.;

SATTASATHUCHANA, P. Association of gingivitis with dental calculus thickness or dental calculus coverage and subgingival bacteria in feline leukemia virus- and feline immunodeficiency virus-negative cats. The Canadian Journal of Veterinary

Research, v. 81, p. 46-52, 2017.

TORAL, N.; CONTI, M. A.; SLATER, B. A alimentação saudável na ótica dos adolescents: percepções e barreiras à sua implementação e características esperadas em materiais educativos. Cadernos de Saúde Pública, v. 25, n. 11, p. 2386-2394, 2009.

TORRES, H. C.; CANDIDO, N. A.; ALEXANDRE, L. R.; PEREIRA, F. L. O processo de elaboração de cartilhas para orientação do autocuidado no programa educativo em Diabetes. Revista Brasileira de Enfermagem, v. 62, n. 2, p. 312-316, 2009.

TRINDADE, P. Na contramão da crise econômica, mercado pet cresce. FECOMERCIO. In: Negócios: serviços. Disponível em:

$<w w w$.fecomercio.com.br/noticia/na-contramao-da-crise-economica-mercado-petcresce >. Acessado em 22 mar. 2018.

TROMP, M.; BUCKLEY, H.; GEBER, J.; MATISOO-SMITH, E. EDTA decalcification of dental calculus as an alternate means of microparticle extraction from archaeological samples. Journal of Archaeological Science: Reports, v. 14, p. 461-466, 2017.

TROXEL, M. latrogenic traumatic brain injury during tooth extraction. Journal of American Animal Hospital Association, v. 51, n. 2, 2015.

TUTT, C. Small animal dentistry: a manual of techniques. Oxford: Blackwell, 2006. $282 \mathrm{p}$.

URAL, S. E.; AKBAY, S.; ALTAY, B. Progression of color decision making in introductory design education. Color Research and Application, v. 42, n. 6, p. 849860, 2017. 
VIEIRA, S. Como elaborar questionários. São Paulo: Atlas, 2009.

WIGGS, R. B.; LOBPRISE, H. B. Veterinary dentistry: principles and practice. Philadelphia: Lippincott-Raven, 1997. 748 p.

WOLF, H. F.; RATEITSCHAK, E. M.; RATEITSCHAK, K. H.; HASSEL, T. M. Color atlas of dental medicine: periodontology, 3. ed. Stuttgart: Georg Thieme Verlag, 2005.

WRIGHT, B.; RAINWATER, L. The meanings of color. The Journal of General Psychology, v. 67, n. 1, p. 89-99, 1962.

YASUI, T.; MABUCHI, Y.; MORIKAWA, S.; ONIZAWA, K.; AKAZAWA, C.; NAKAGAWA, T.; OKANO, H.; MATSUZAKI, Y. Isolation of dental pulp stem cells with high osteogenic potential. Inflammation and Regeneration, v. 37, n. 8, 2017.

ZOMBINI, E. V.; PELICIONI, M. C. F. Estratégias para a avaliação de um material educativo em saúde ocular. Revista Brasileira do Crescimento e Desenvolvimento Humano, v. 21, p. 51-58, 2011. 
APÊNDICES 
APÊNDICE A - INSTRUMENTO DE AVALIAÇÃO 


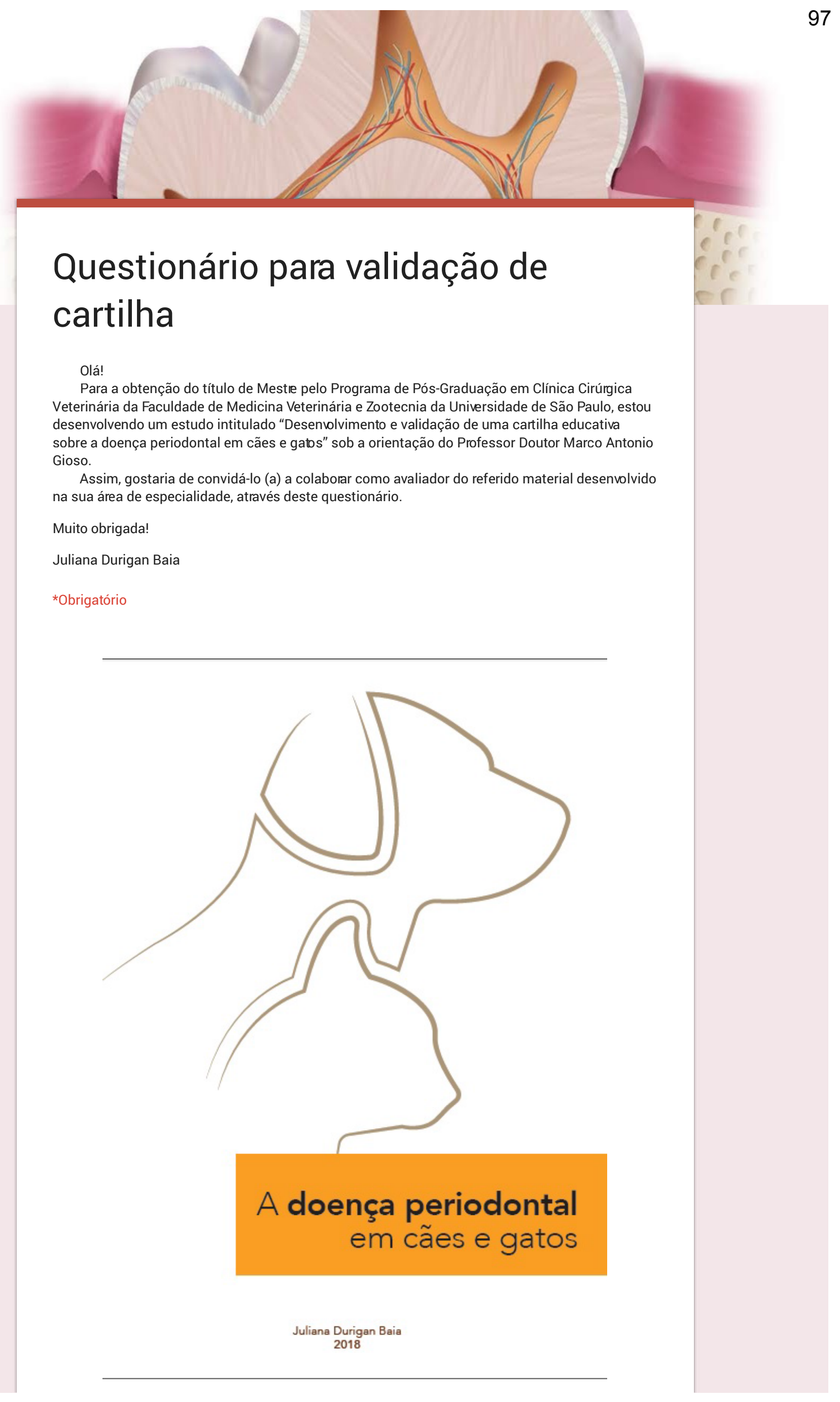




\section{DADOS PESSOAIS}
Faixa etária *
Menor que 20 anos
- 21 - 30 anos
31- 40 anos
41-50 anos
51- 60 anos
61 - 70 anos
Maior que 70 anos
Outro:

Sexo *

Feminino

Masculino

\section{QUESTÕES REFERENTES AO CONTEÚDO DA CARTILHA \\ EDUCATIVA}

Por gentileza, leia com atenção cada afirmação e, em seguida, escolha a opção de resposta que melhor representa a sua opinião, de acordo com a escala de níveis de concordância.

Legenda da escala de respostas:

$1=$ Concordo totalmente

$2=$ Concordo parcialmente

$3=$ Indiferente

4 = Discordo parcialmente

$5=$ Discordo totalmente

O material aborda o tema "doença periodontal" de maneira relevante. *

$\begin{array}{ccccccc} & 1 & 2 & 3 & 4 & 5 & \\ \begin{array}{c}\text { Concordo } \\ \text { totalmente }\end{array} & 0 & 0 & \bigcirc & \bigcirc & \bigcirc & \begin{array}{r}\text { Discordo } \\ \text { totalmente }\end{array}\end{array}$

O material traz esclarecimentos a respeito da importância do correto diagnóstico da doença periodontal.*

$\begin{array}{ccccccc} & 1 & 2 & 3 & 4 & 5 & \\ \begin{array}{c}\text { Concordo } \\ \text { totalmente }\end{array} & 0 & \bigcirc & \bigcirc & \bigcirc & \bigcirc & \begin{array}{r}\text { Discordo } \\ \text { totalmente }\end{array}\end{array}$


O material traz esclarecimentos a respeito da importância do correto tratamento da doença periodontal. *

$\begin{array}{ccccccc}\begin{array}{c}\text { Concordo } \\ \text { totalmente }\end{array} & 1 & 2 & 3 & 4 & 5 & \\ \text { Discordo } \\ \text { totalmente }\end{array}$

O material traz esclarecimentos a respeito dos efeitos sistêmicos da doença periodontal em cães e gatos. *

$\begin{array}{ccccccc} & 1 & 2 & 3 & 4 & 5 & \\ \begin{array}{c}\text { Concordo } \\ \text { totalmente }\end{array} & \bigcirc & 0 & \bigcirc & \bigcirc & \bigcirc & \begin{array}{r}\text { Discordo } \\ \text { totalmente }\end{array}\end{array}$

O material alerta a respeito dos riscos das lesões iatrogênicas e suas possíveis consequências legais. *

$\begin{array}{ccccccc} & 1 & 2 & 3 & 4 & 5 & \\ \begin{array}{ccccc}\text { Concordo } \\ \text { totalmente }\end{array} & \bigcirc & \bigcirc & \bigcirc & \bigcirc & \bigcirc & \begin{array}{c}\text { Discordo } \\ \text { totalmente }\end{array}\end{array}$

0 material traz esclarecimentos a respeito de erros conceituais comuns na prática odontológica veterinária. *

$\begin{array}{ccccccc} & 1 & 2 & 3 & 4 & 5 & \\ \begin{array}{c}\text { Concordo } \\ \text { totalmente }\end{array} & \bigcirc & \bigcirc & \bigcirc & \bigcirc & \bigcirc & \begin{array}{r}\text { Discordo } \\ \text { totalmente }\end{array}\end{array}$

O material apresenta suas informações de maneira clara e objetiva. *

$\begin{array}{ccccccc} & 1 & 2 & 3 & 4 & 5 & \\ \begin{array}{c}\text { Concordo } \\ \text { totalmente }\end{array} & \bigcirc & \bigcirc & \bigcirc & \bigcirc & \bigcirc & \begin{array}{r}\text { Discordo } \\ \text { totalmente }\end{array}\end{array}$

O material pode ser considerado relevante para o público-alvo que se destina. *

$\begin{array}{ccccccc} & 1 & 2 & 3 & 4 & 5 & \\ \begin{array}{c}\text { Concordo } \\ \text { totalmente }\end{array} & 0 & \bigcirc & \bigcirc & \bigcirc & \bigcirc & \begin{array}{r}\text { Discordo } \\ \text { totalmente }\end{array}\end{array}$

O material estimula o interesse do leitor a respeito da doença periodontal em cães e gatos. * 
Concordo

totalmente

$\begin{array}{llll}2 & 3 & 4 & 5\end{array}$

O material permite a aplicação de seu conteúdo na pática profissional do Médico Veterinário. *

$\begin{array}{ccccccc} & 1 & 2 & 3 & 4 & 5 & \\ \begin{array}{c}\text { Concordo } \\ \text { totalmente }\end{array} & 0 & \bigcirc & \bigcirc & \bigcirc & \bigcirc & \begin{array}{r}\text { Discordo } \\ \text { totalmente }\end{array}\end{array}$

\section{QUESTÕES REFERENTES AO ASPECTO VISUAL DA CARTILHA EDUCATIVA}

Do mesmo modo, leia com atenção cada afirmação e, em seguida, escolha a opção de resposta que melhor representa a sua opinião a respeito da afirmação em questão.

A quantidade de páginas pode ser considerada adequada. *

$\begin{array}{ccccccc} & 1 & 2 & 3 & 4 & 5 & \\ \begin{array}{c}\text { Concordo } \\ \text { totalmente }\end{array} & 0 & \bigcirc & \bigcirc & \bigcirc & \bigcirc & \begin{array}{r}\text { Discordo } \\ \text { totalmente }\end{array}\end{array}$

As ilustrações podem ser consideradas adequadas. *

$\begin{array}{ccccccc} & 1 & 2 & 3 & 4 & 5 & \\ \begin{array}{c}\text { Concordo } \\ \text { totalmente }\end{array} & \bigcirc & \bigcirc & \bigcirc & \bigcirc & \bigcirc & \begin{array}{r}\text { Discordo } \\ \text { totalmente }\end{array}\end{array}$

O material apresenta um aspecto visual adequado. *

$\begin{array}{ccccccc} & 1 & 2 & 3 & 4 & 5 & \\ \begin{array}{c}\text { Concordo } \\ \text { totalmente }\end{array} & \bigcirc & 0 & \bigcirc & \bigcirc & \bigcirc & \begin{array}{r}\text { Discordo } \\ \text { totalmente }\end{array}\end{array}$

O tamanho dos títulos, tópicos e textos estão adequados. *

$\begin{array}{ccccccc} & 1 & 2 & 3 & 4 & 5 & \\ \begin{array}{c}\text { Concordo } \\ \text { totalmente }\end{array} & \bigcirc & \bigcirc & \bigcirc & \bigcirc & \bigcirc & \begin{array}{c}\text { Discordo } \\ \text { totalmente }\end{array}\end{array}$

As cores utilizadas estão adequadas. *

$\begin{array}{ccccccc} & 1 & 2 & 3 & 4 & 5 & \\ \begin{array}{c}\text { Concordo } \\ \text { totalmente }\end{array} & 0 & 0 & \bigcirc & \bigcirc & \bigcirc & \begin{array}{r}\text { Discordo } \\ \text { totalmente }\end{array}\end{array}$


Concordo

totalmente

$\begin{array}{lllll}1 & 2 & 3 & 4 & 5\end{array}$

\section{CONSIDERAÇÕES FINAIS}

Cartilhas educativas podem ser consideradas importantes ferramentas complementares para o ensino da doença periodontal em cães e gatos. *

$\begin{array}{ccccccc} & 1 & 2 & 3 & 4 & 5 & \\ \begin{array}{ccccc}\text { Concordo } \\ \text { totalmente }\end{array} & 0 & 0 & \bigcirc & \bigcirc & \bigcirc & \begin{array}{r}\text { Discordo } \\ \text { totalmente }\end{array}\end{array}$

Eu acredito que a doença periodontal deveria ser melhor abordada na graduação de Medicina Veterinária. *

$\begin{array}{ccccccc} & 1 & 2 & 3 & 4 & 5 & \\ \begin{array}{c}\text { Concordo } \\ \text { totalmente }\end{array} & \bigcirc & \bigcirc & \bigcirc & \bigcirc & \bigcirc & \begin{array}{r}\text { Discordo } \\ \text { totalmente }\end{array}\end{array}$

\section{Muito obrigada pela colaboração!}

\section{ENVIAR}

Nunca envie senhas pelo Formulários Google. 
APÊNDICE B - CARTILHA EDUCATIVA 


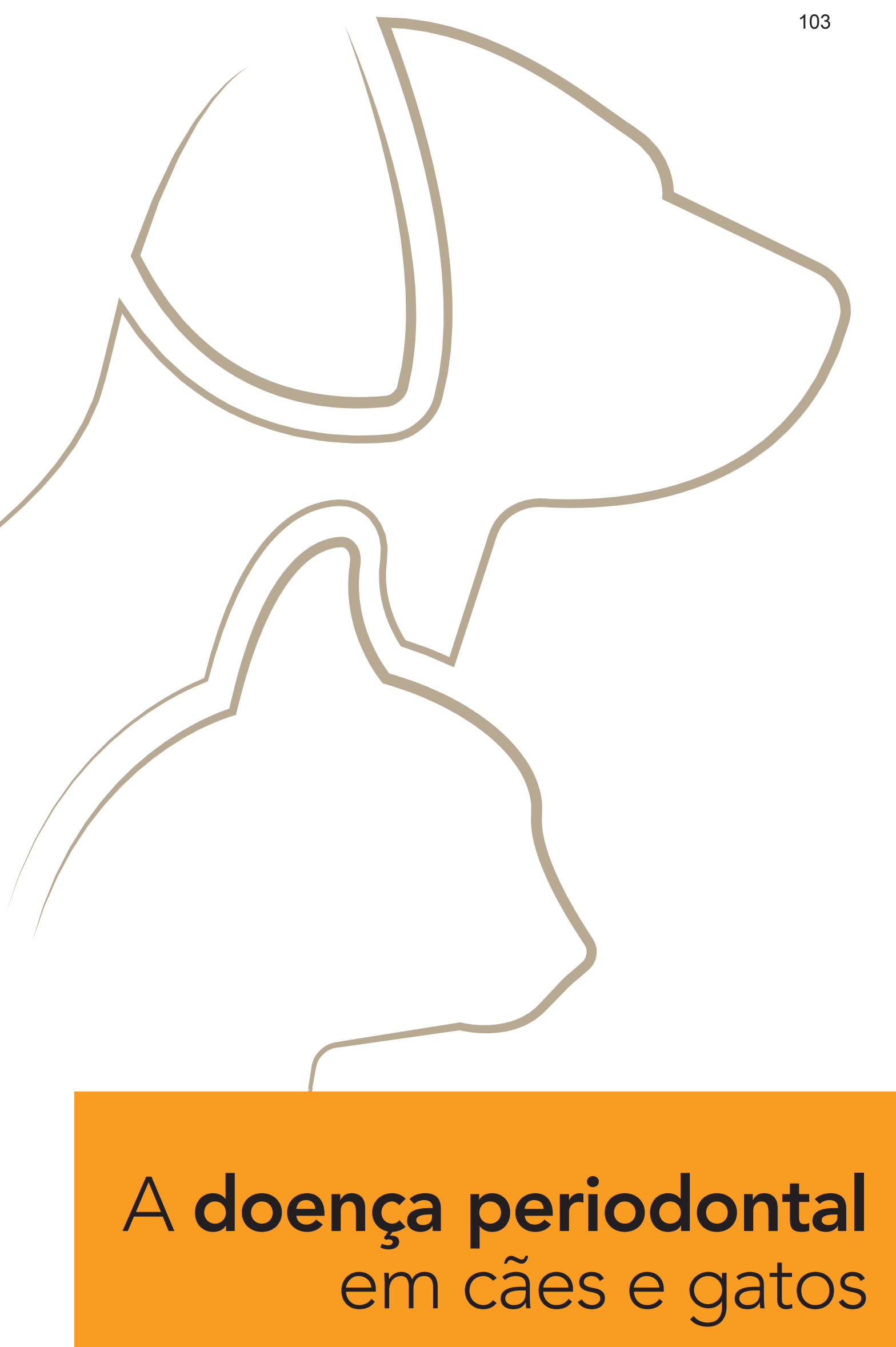

Juliana Durigan Baia

2018 


\section{Juliana Durigan Baia}

2018

Todos os direitos reservados.

Autorizo a reprodução parcial ou total desta obra, para fins acadêmicos, desde que citada a fonte. 
"A educação é importante demais para entregá-la às variações do mercado e às boas intenções de amadores."

Diane Ravitch 


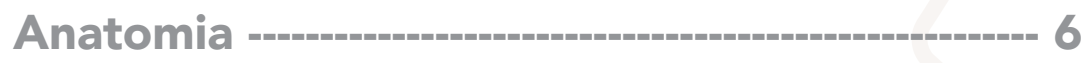

Doença periodontal ---on 9

Tratamento periodontal ------------------------------ 16

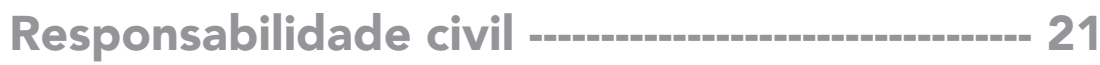

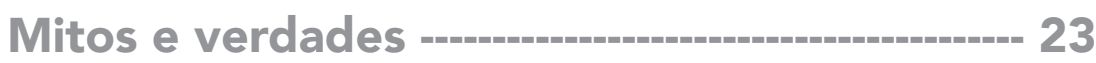




\section{APRESENTAÇÃO}

De acordo com a lei 5.517, de 23 de outubro de 1968, a prática da clínica em todas as suas modalidades é de competência privativa do médico veterinário.

Mesmo não possuindo pós-graduação em odontologia veterinária, o médico veterinário pode atuar nesta área. Infelizmente, na maioria das faculdades, a odontologia veterinária é uma disciplina ausente ou pouco discutida durante a graduação. Por muitas vezes a doença periodontal tem seus efeitos locais e sistêmicos desconhecidos ou desconsiderados pelo médico veterinário. Consequentemente, estes profissionais instauram tratamentos incompletos ou incorretos para esta afecção, gerando lesões iatrogênicas aos pacientes e tornando-se alvos de processos éticos, civis e penais. $O$ médico veterinário precisa estar preparado para identificar e tratar corretamente as afecções orais em seus pacientes e, sempre que for necessário, encaminhá-los aos colegas especializados em odontologia veterinária, priorizando o bem-estar destes animais.

No intuito de oferecer uma estratégia pedagógica, como proposta de educação complementar, que estimule o médico veterinário a conhecer melhor a afecção que acomete mais de $70 \%$ dos cães e gatos adultos, desenvolveu-se esta cartilha educativa como parte de um projeto de pós-graduação stricto sensu. Esta ferramenta de ensino aborda diversos tópicos que visam contribuir com a rotina clínica do profissional, além de estimular o interesse e a compreensão deste tema tão complexo.

Espera-se que, após a leitura atenta deste material, o profissional compreenda a importância da saúde oral para a saúde sistêmica de seus pacientes e transmita estes conhecimentos para seus clientes e colegas de profissão.

Boa leitura! 


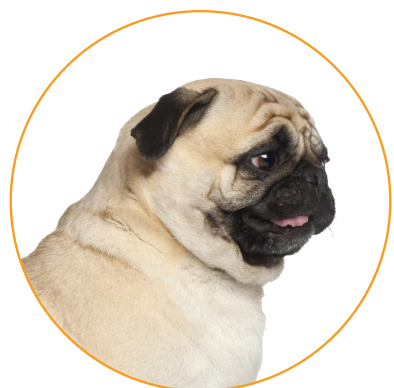

Braquicefálico

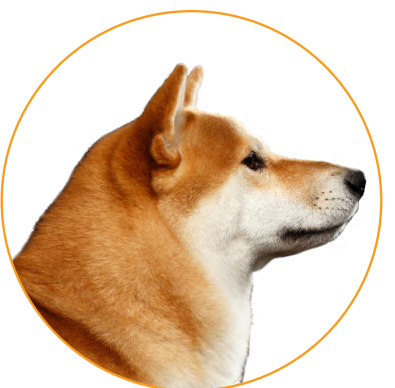

Mesaticefálico

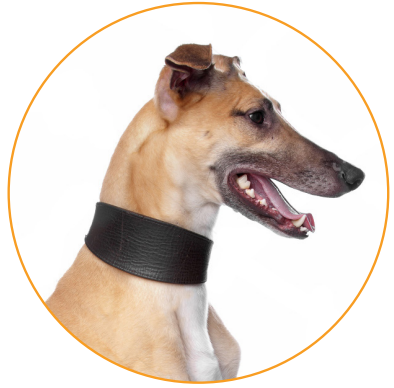

Dolicocefálico

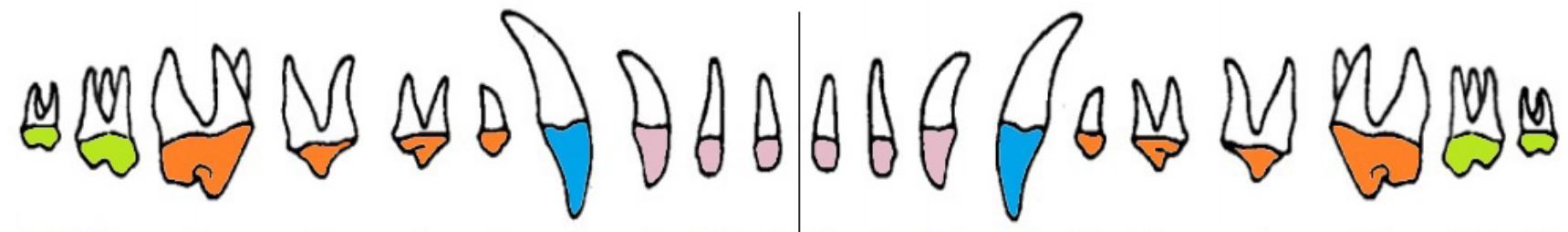

\begin{tabular}{lllllllllll|llllllllllll} 
& 110 & 109 & 108 & 107 & 106 & 105 & 104 & 103 & 102 & 101 & 201 & 202 & 203 & 204 & 205 & 206 & 207 & 208 & 209 & 210 & & \\
\hline 411 & 410 & 409 & 408 & 407 & 406 & 405 & 404 & 403 & 402 & 401 & 301 & 302 & 303 & 304 & 305 & 306 & 307 & 308 & 309 & 310 & 311
\end{tabular}

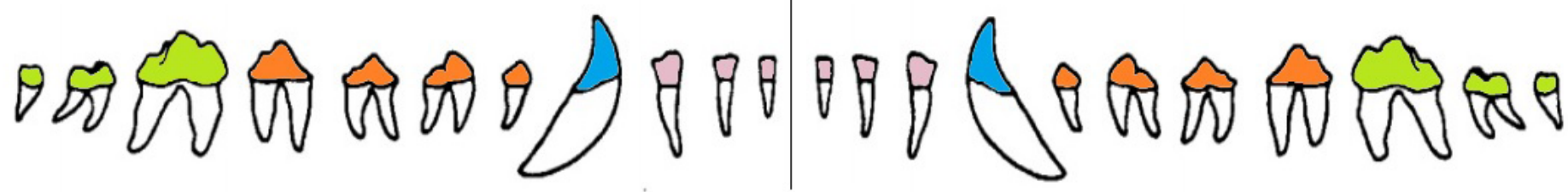

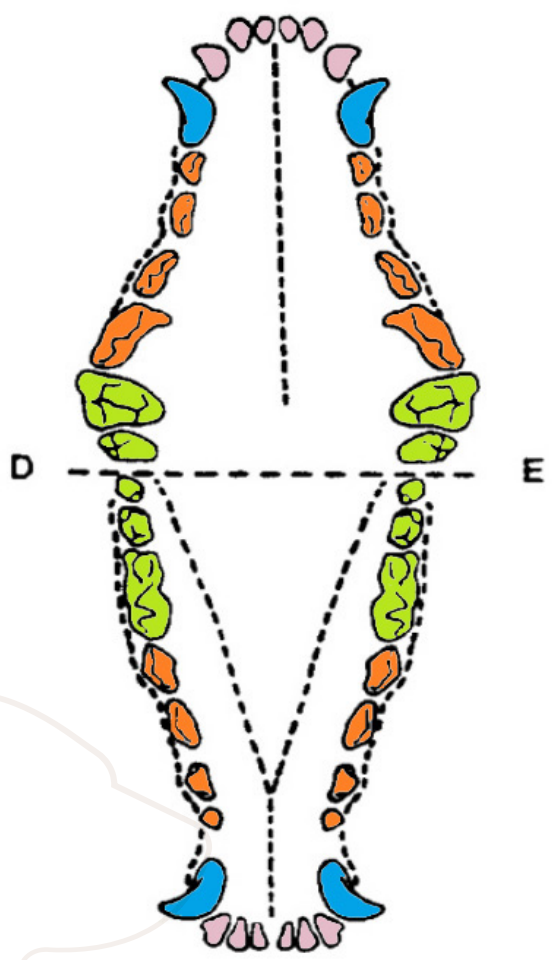

Representação da arcada dentária completa do cão.
O cão apresenta 28 dentes decíduos - popularmente conhecidos como dentes "de leite" - que começam a se formar ainda no útero materno e erupcionam a partir da terceira semana de vida. Já a troca pela dentição permanente normalmente ocorre entre 3 e 7 meses de idade, resultando em um total de 42 dentes permanentes.

$\begin{array}{lll} & \begin{array}{l}\text { Tempo médio de } \\ \text { erupção de dentes } \\ \text { decíduos }\end{array} & \begin{array}{l}\text { Tempo médio de } \\ \text { erupção de dentes } \\ \text { permanentes }\end{array} \\ \text { Incisivos } & 4-6 \text { semanas } & 3-4 \text { meses } \\ \text { Caninos } & 3-5 \text { semanas } & 3-4 \text { meses } \\ \text { Pré-molares } & 5 \text { - } 6 \text { semanas } & 4-5 \text { meses } \\ \text { Molares } & \text { Ausentes } & 4-7 \text { meses }\end{array}$




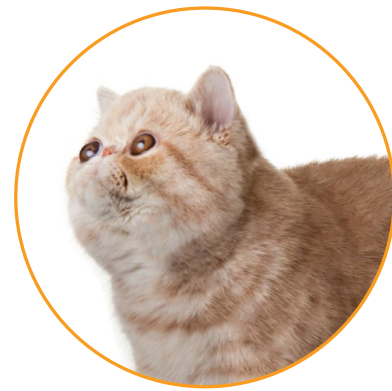

Braquicefálico

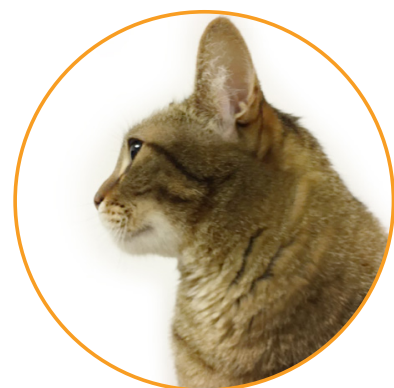

Mesaticefálico

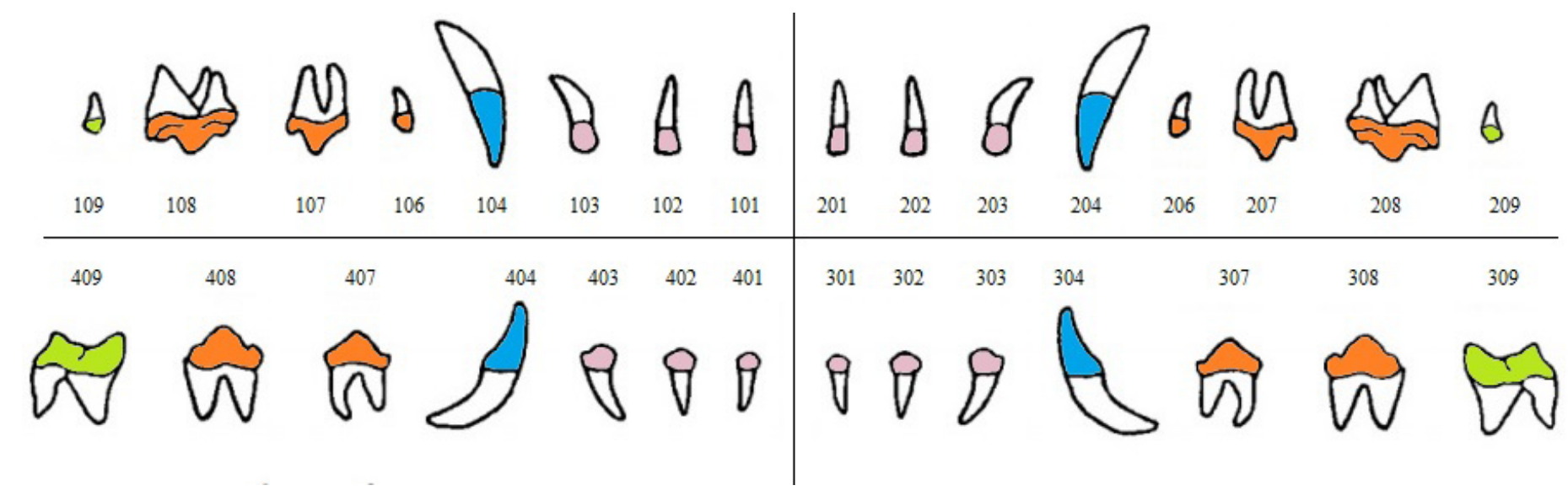

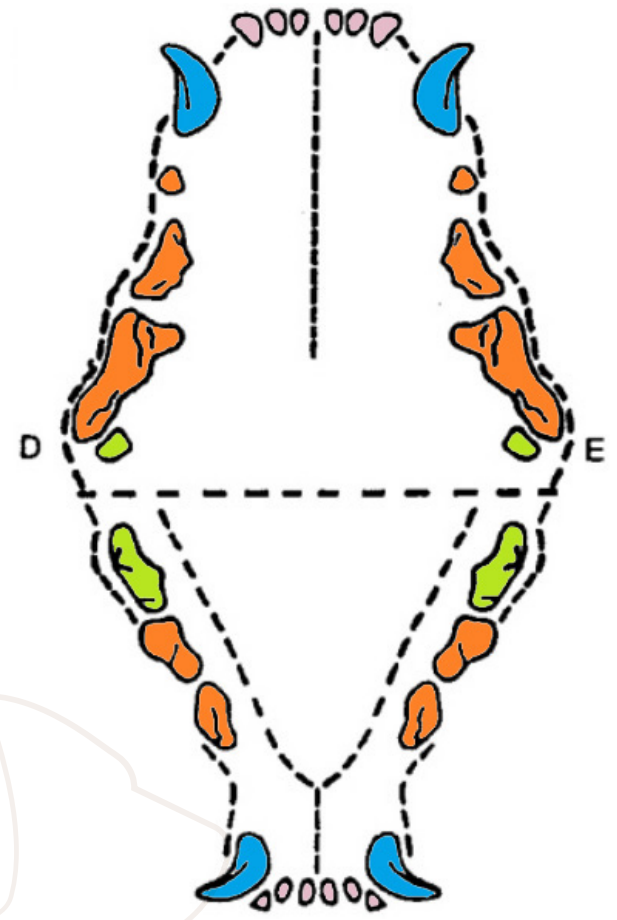

Representação da arcada dentária completa do gato.
O gato apresenta 26 dentes decíduos que, assim como o cão, começam a se formar ainda no útero materno e erupcionam a partir da terceira semana de vida, trocando a dentição decídua pela permanente entre 3 e 7 meses de idade, resultando em um total de 30 dentes permanentes.
Tempo médio de erupção de dentes decíduos

Incisivos

Caninos

Pré-molares

Molares
3 - 4 semanas

3 - 4 semanas

5 - 6 semanas

Ausentes
Tempo médio de erupção de dentes permanentes

3 - 4 meses

3 - 5 meses

4 - 5 meses

5 - 7 meses 


\section{ANATOMIA D PERIODONTO}
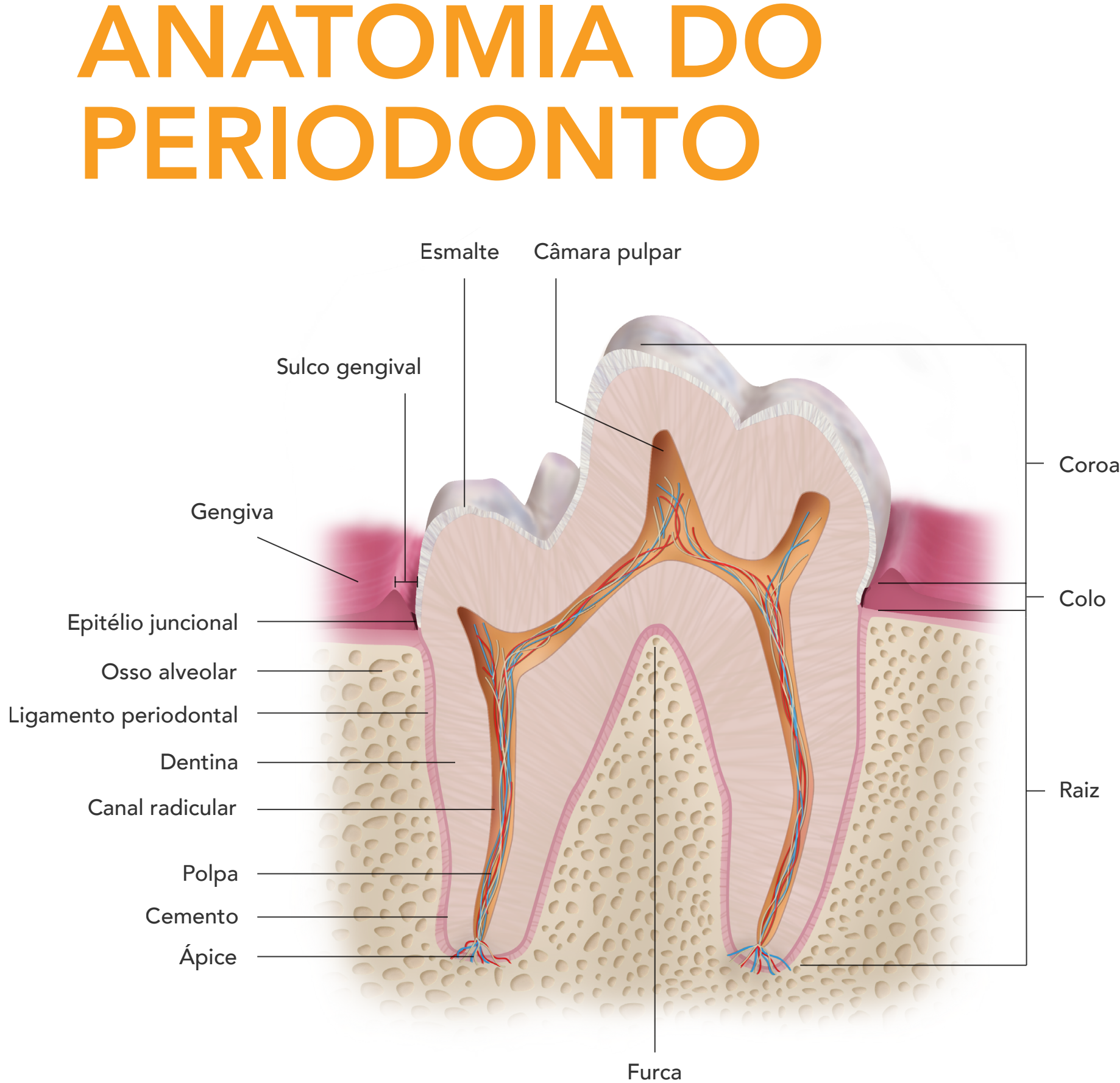

O periodonto é definido como o conjunto das seguintes estruturas: cemento, gengiva, ligamento periodontal e osso alveolar. Tais estruturas têm como principais funções a proteção e o suporte do dente. Considera-se periodonto de sustentação o cemento, o ligamento periodontal e o osso alveolar, pois são estas as estruturas que garantem a sustentação do dente. Já a gengiva é classificada como periodonto de proteção, pois serve de barreira física contra impactos e invasão microbiana. 


\section{DOENCA PERIODOONTAL}

A microbiota fisiologicamente presente na cavidade oral tem a capacidade de aderir-se aos dentes imediatamente após a limpeza da superfície dentária, organizando-se em forma de um biofilme que, na cavidade oral, chama-se placa bacteriana. Para que a placa bacteriana lesione os tecidos periodontais, dando início à doença periodontal, deve haver um contínuo acúmulo e organização de seus constituintes. Sendo assim, conforme ocorre o acúmulo de placa e formação de cálculo dentário, o sulco gengival torna-se um ambiente propício para a proliferação de bactérias altamente patogênicas ao periodonto, como bacilos, filamentos e espiroquetas gram-negativas, anaeróbias facultativas e estritas.

A placa bacteriana instalada estimula o processo inflamatório local e, se não for corretamente removida, causa degeneração e migração do epitélio juncional, que é uma importante ferramenta de defesa do periodonto.

A bolsa periodontal é o resultado desta degeneração e migração do epitélio juncional, tornando-se um sulco gengival patologicamente aprofundado. Considera-se esta uma característica importante da doença periodontal, pois não é revertida espontaneamente. 


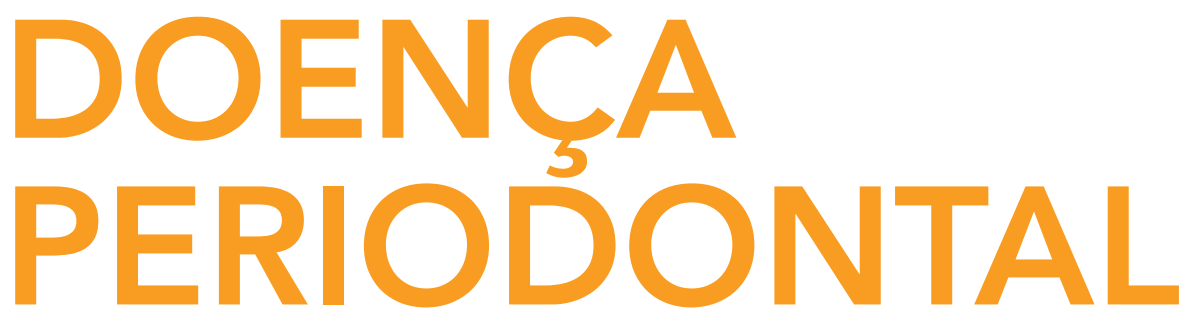

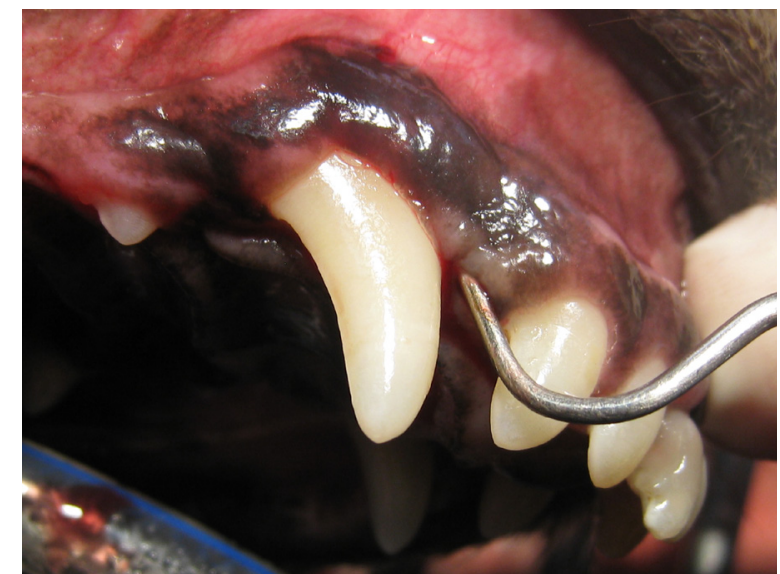

Dente canino superior direito de um cão, aparentemente hígido. Após sondagem periodontal, nota-se presença de bolsa periodontal.

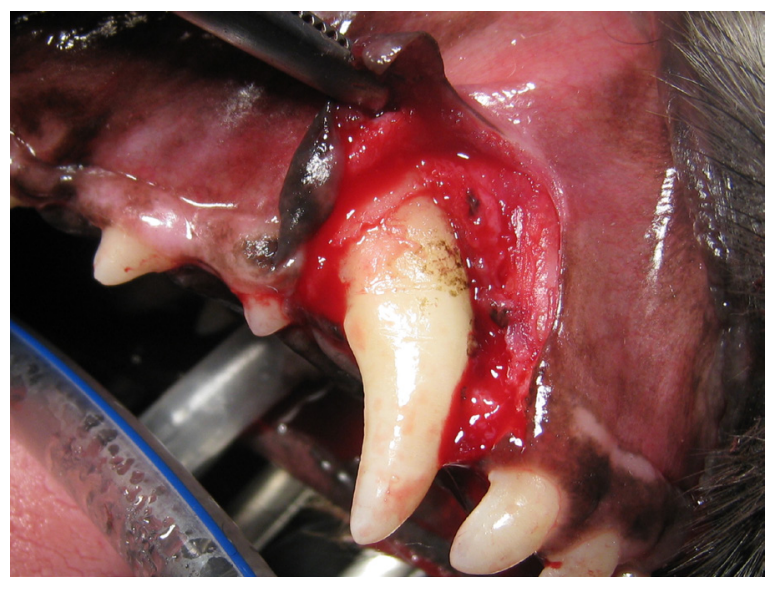

A partir da exposição da região subgengival é possível notar perda óssea, acúmulo de placa bacteriana e cálculo dentário na região radicular exposta.

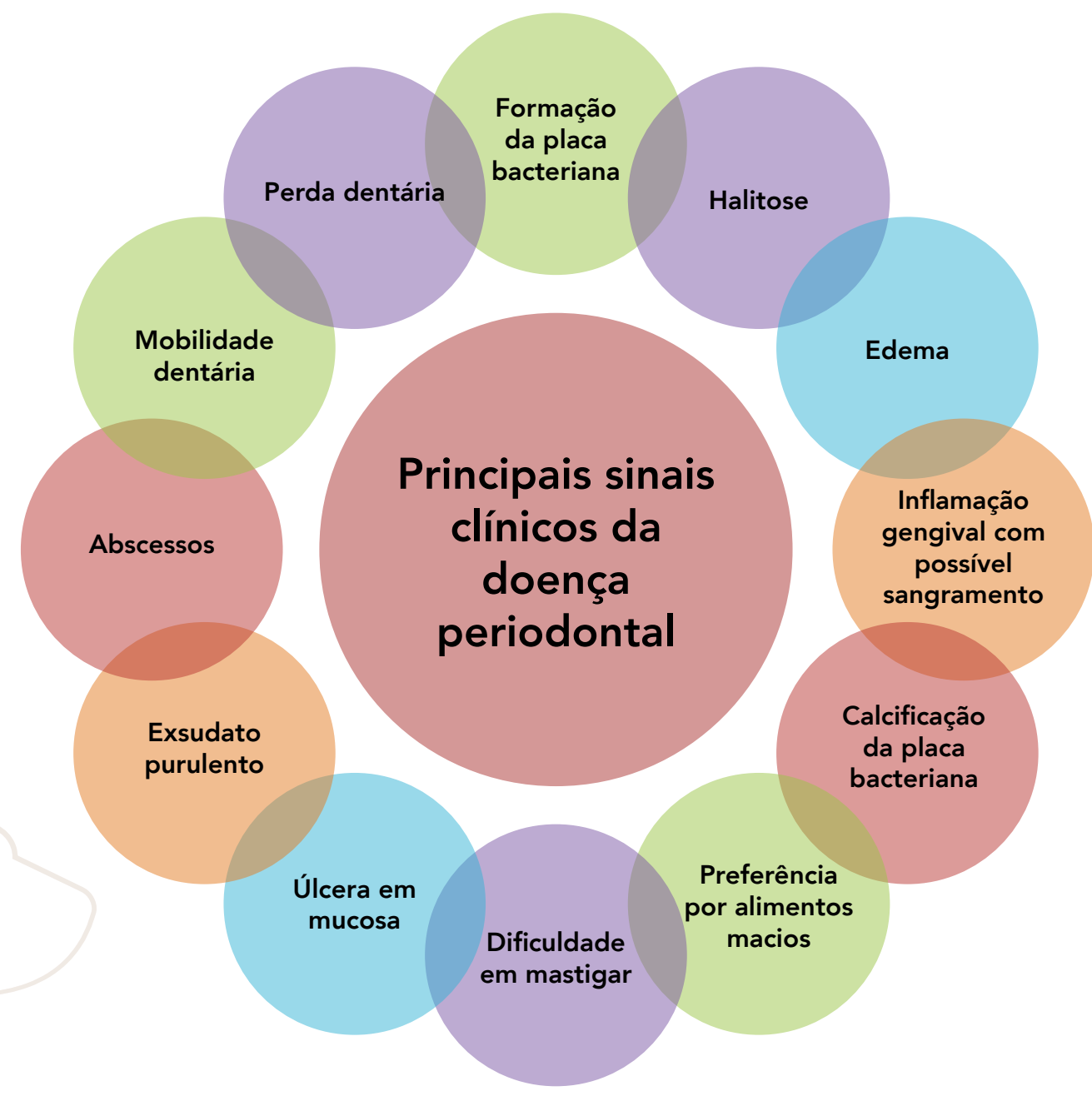




\section{EFEITOS SISTÊMICOS DA DOENÇA PERIODONTAL}

A relação entre a doença periodontal e o comprometimento da saúde sistêmica está estabelecida há muito tempo!

A periodontite contribui para o desenvolvimento de diversas afecções inflamatórias sistêmicas. Isto ocorre principalmente por três mecanismos: bacteremia, anacorese e atividade colagenolítica.

O processo mastigatório diário dos animais que apresentam bolsa periodontal e inflamação gengival favorece o acesso de bactérias e seus fragmentos aos vasos sanguíneos, o que é conhecido por bacteremia. A bacteremia favorece a anacorese, fenômeno que leva bactérias e seus fragmentos, através dos vasos sanguíneos, aos tecidos inflamados. Frequentes episódios de bacteremia ocorrem todos os dias, durante anos, podendo causar infecção ou estimular a inflamação em diversos órgãos como coração, fígado, rins, órgãos do trato respiratório e também as articulações.

Sabe-se que a resposta inflamatória é muito importante para a vida dos animais. A inflamação regula a defesa do corpo contra patógenos, estresse ambiental, além de controlar a recuperação de feridas.

A inflamação aguda como em resposta à lesão tecidual ou infecção ocorre praticamente de imediato. Esta fase é curta e normalmente resulta na recuperação do equilíbrio fisiológico. A inflamação aguda é atualmente definida como uma resposta fisiológica que ocorre em tecidos vascularizados para proteger o animal e manter sua homeostase. O processo de inflamação aguda caracteriza-se pela dilatação vascular, aumento da permeabilidade de capilares, do fluxo sanguíneo e do recrutamento de leucócitos, que são células com função de defender o organismo.

Quando permanece após o período transitório da resposta imune inata para adquirida, a inflamação torna-se crônica. Nesta fase, há aumento de atividade destrutiva de colágeno. Sendo o colágeno a proteína mais abundante do corpo humano e animal, presente em praticamente todos os órgãos, a inflamação crônica lesiona diversos órgãos e tecidos. 


\section{ESTÁGIOS \\ DA DOENÇA PERIODONTAL}

\section{Estágio 1 - Gengivite}

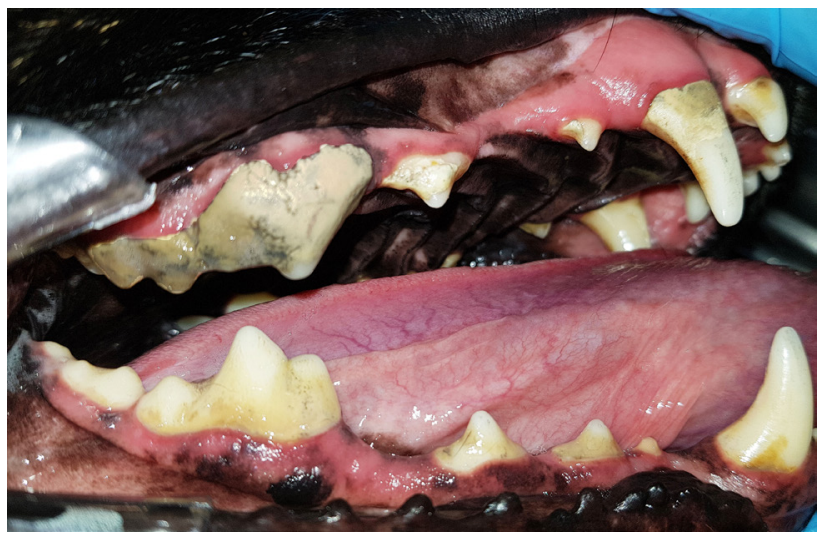

Observa-se presença generalizada de inflamação gengival e cálculo dentário em cavidade oral de cão.

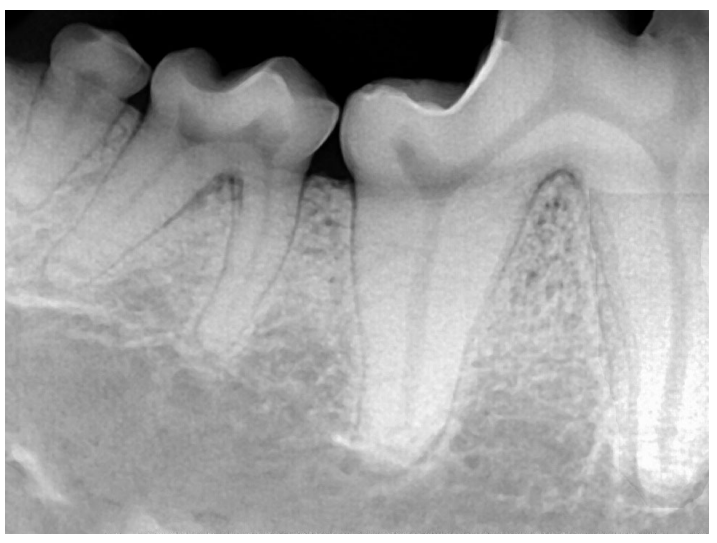

Radiograficamente, este mesmo paciente apresenta periodonto hígido, sem perda óssea.

\section{Uma boca "suja" nem sempre é uma boca doente!}

O correto diagnóstico da doença periodontal depende da realização de radiografia intraoral.

Neste estágio não há perda óssea. Pode-se observar, entretanto, a presença de inflamação gengival e cálculo dentário. 


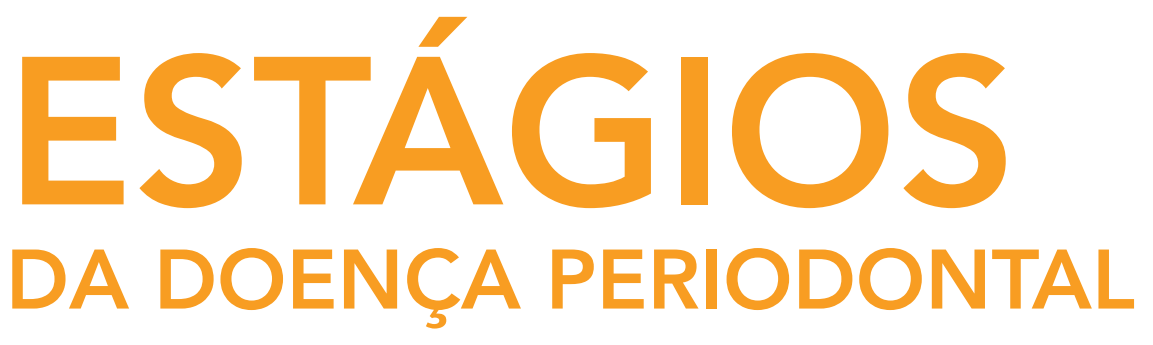

Estágio 2 - Periodontite leve

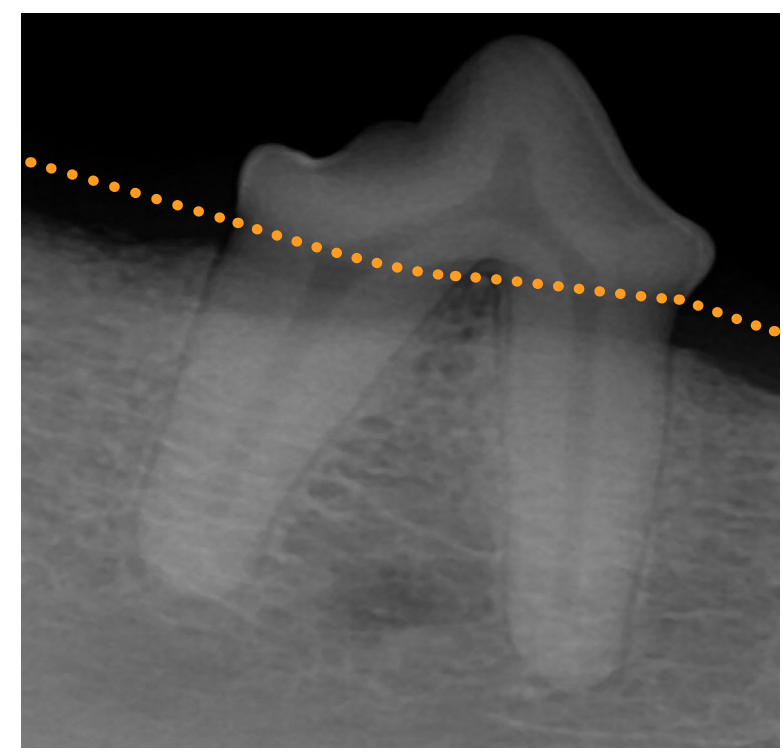

Radiografia intraoral de paciente canino, demonstrando a altura óssea esperada para dentes hígidos a partir da linha pontilhada.

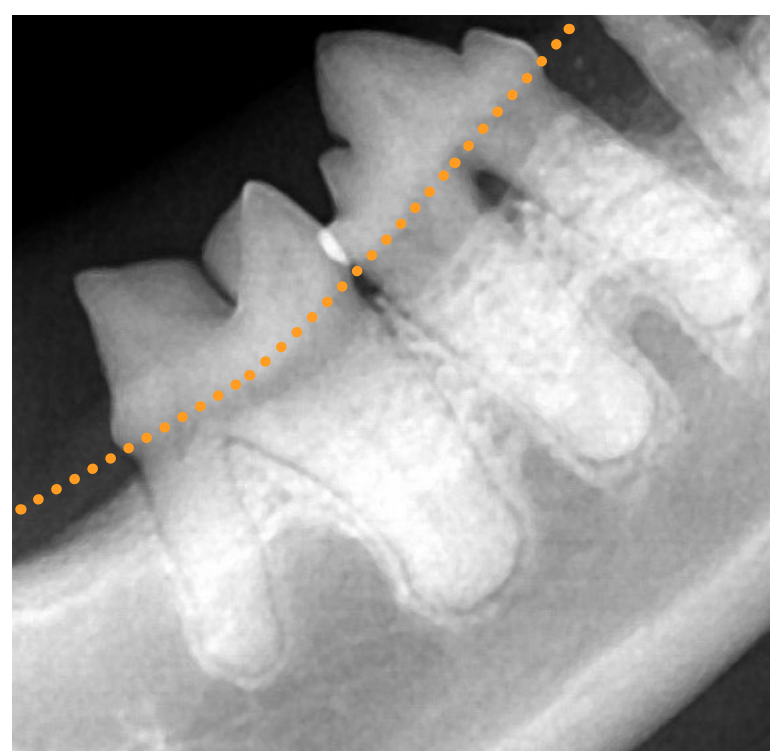

Radiografia intraoral de paciente felino, demonstrando a altura óssea esperada para dentes hígidos a partir da linha pontilhada.

Neste estágio, a partir da realização de radiografia intraoral, nota-se perda óssea menor que $25 \%$. Clinicamente, a cavidade oral pode apresentar apenas inflamação gengival e cálculo dentário, assim como no estágio anterior. 


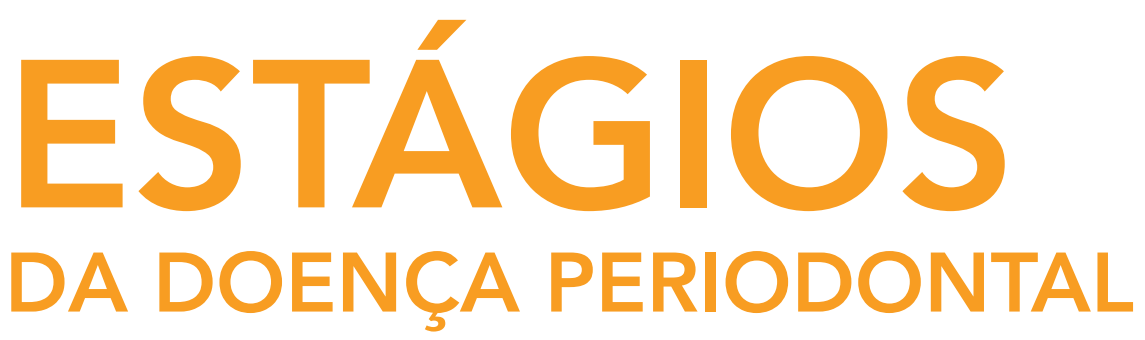

\section{Estágio 3 - Periodontite moderada}

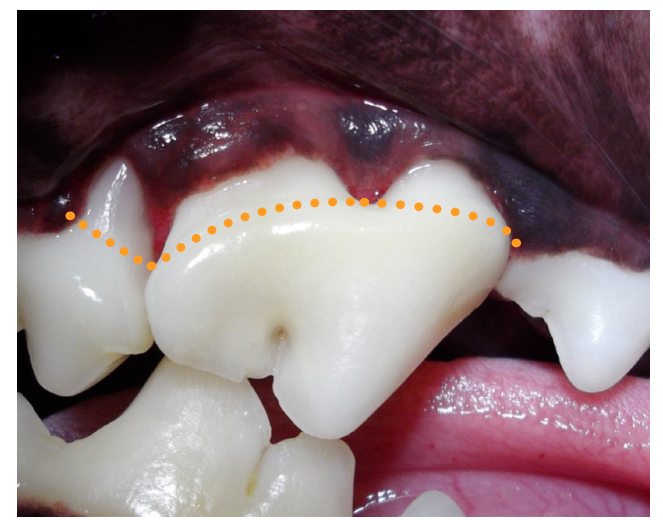

Neste cão, a linha pontilhada representa a altura gengival esperada em periodonto hígido.

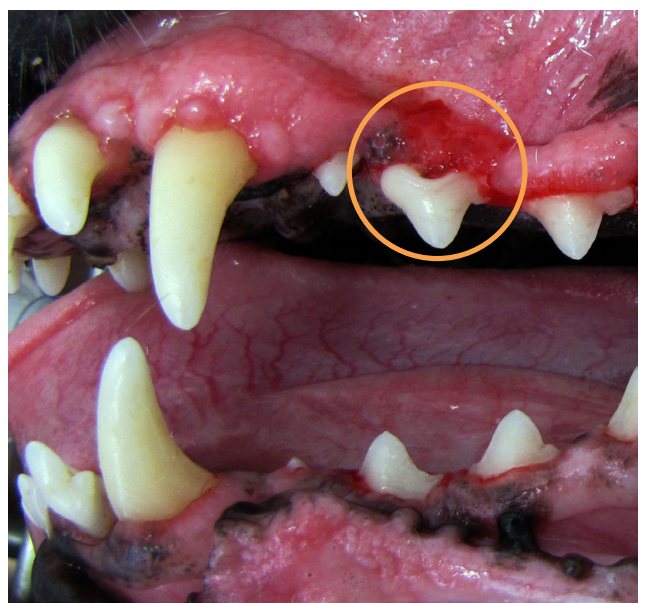

Este paciente canino apresenta, além de áreas de hiperplasia e inflamação gengival, exposição de furca demonstrada pelo círculo.

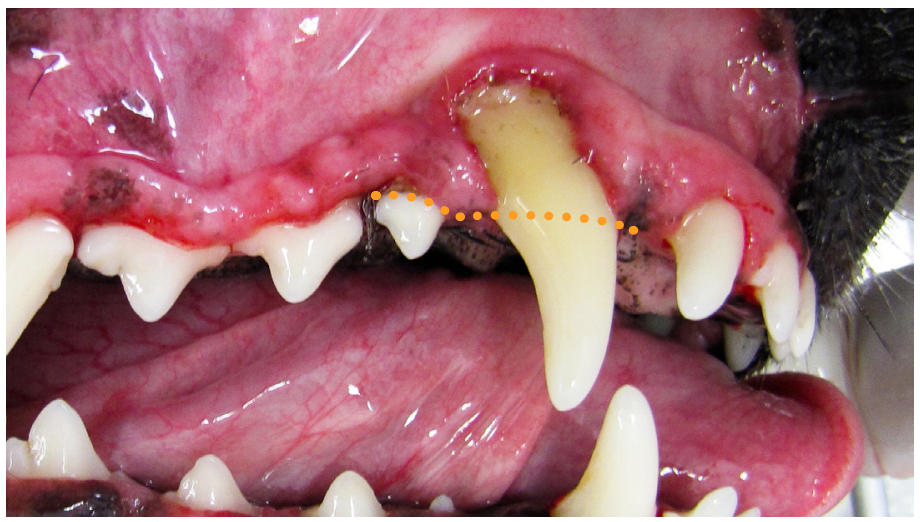

Assim como na imagem anterior, a linha pontilhada representa a altura gengival esperada em periodonto canino hígido.

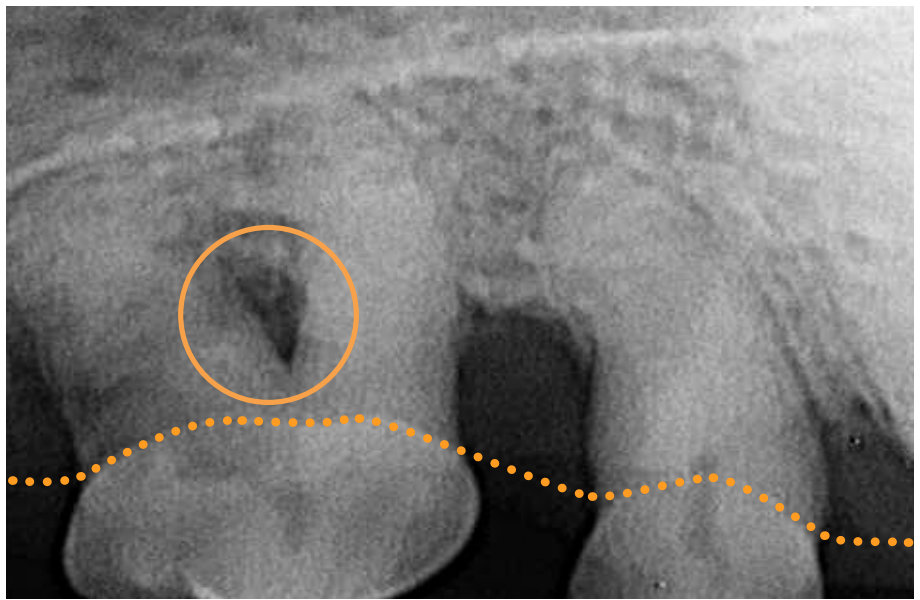

Radiografia intraoral de paciente canino, demonstrando a altura óssea esperada para dentes hígidos a partir da linha pontilhada, além de exposição de furca demonstrada pelo círculo.

Clinicamente, a cavidade oral pode apresentar inflamação gengival, hiperplasia ou retração gengival, além de cálculo dentário. Neste estágio, há perda óssea de 25 a 50\%. Dentes com múltiplas raízes podem apresentar exposição de furca, em virtude de retração gengival e perda óssea. 


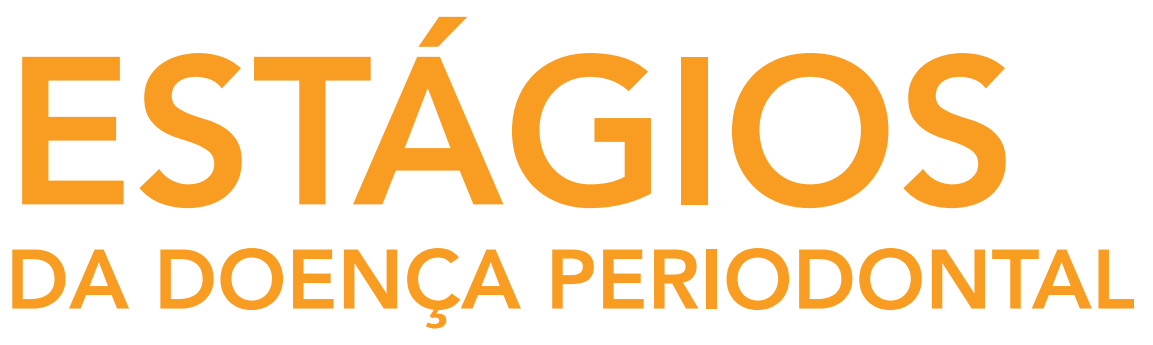

\section{Estágio 4 - Periodontite avançada}

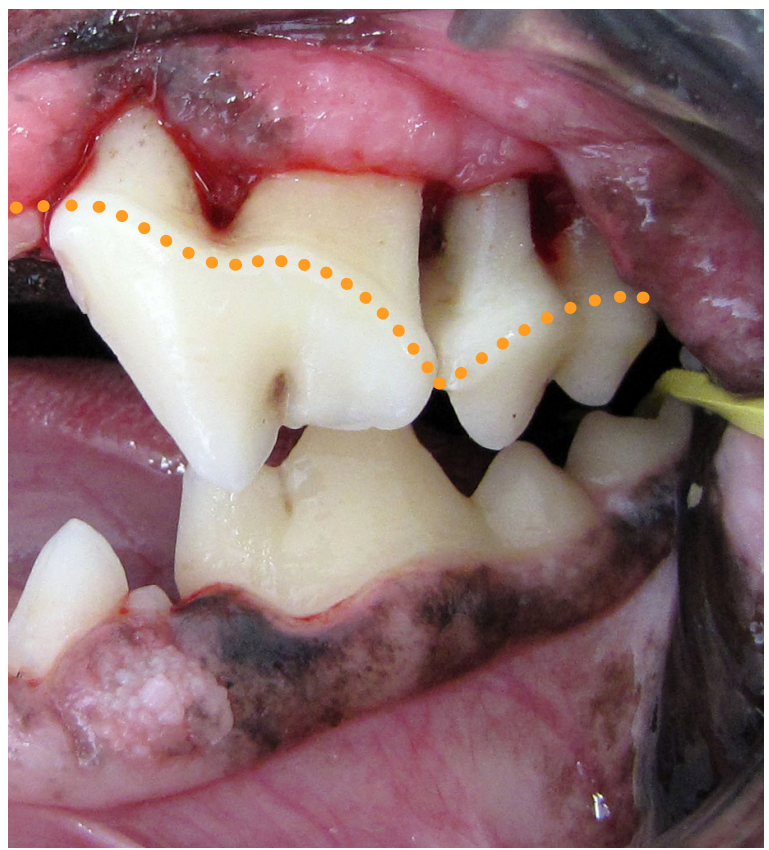

Neste cão, a linha pontilhada representa a altura gengival esperada em periodonto hígido.

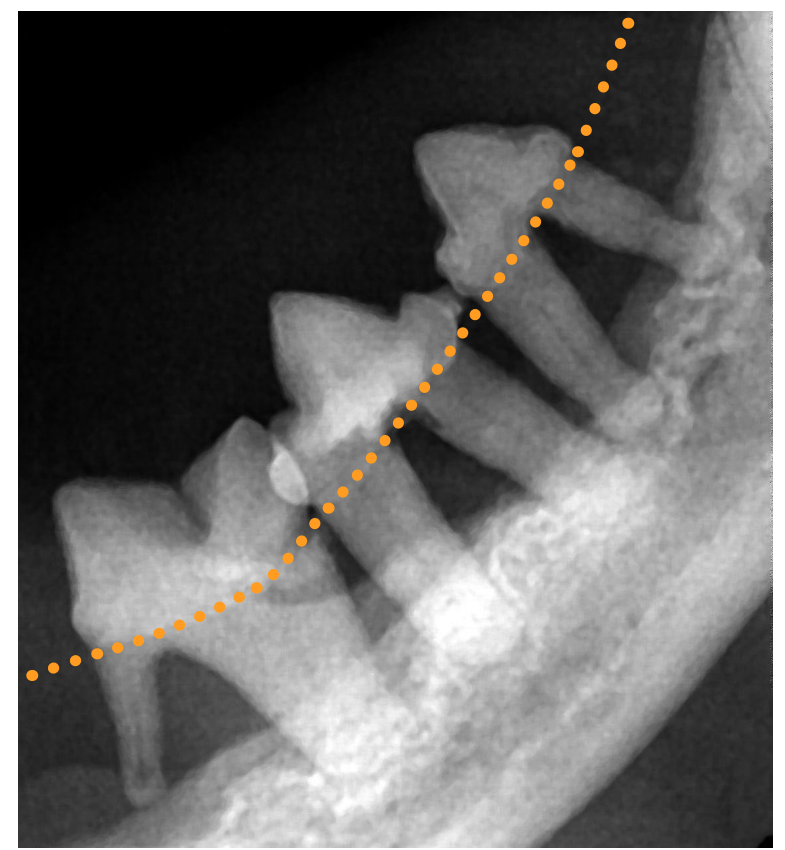

Radiografia intraoral de paciente felino, demonstrando a altura óssea esperada para dentes hígidos a partir da linha pontilhada.

A periodontite avançada apresenta perda óssea maior que $50 \%$.

Dentes com múltiplas raízes podem apresentar exposição de furca. 


\section{CONSIDERAÇÕES DO TRATAMENTỎ PERIODONTAL}

Os aspectos a serem considerados no tratamento periodontal variam de acordo com cada estágio da doença periodontal.

A caracterização dos estágios desta afecção é realizada de maneira individual a cada elemento dentário.

Logo, uma mesma cavidade oral pode apresentar diferentes estágios de periodontite! Desta forma, o tratamento periodontal deve ser realizado de acordo com as necessidades específicas de cada elemento dentário do paciente, em nível supragengival e subgengival, a partir da utilização de instrumentos odontológicos específicos.
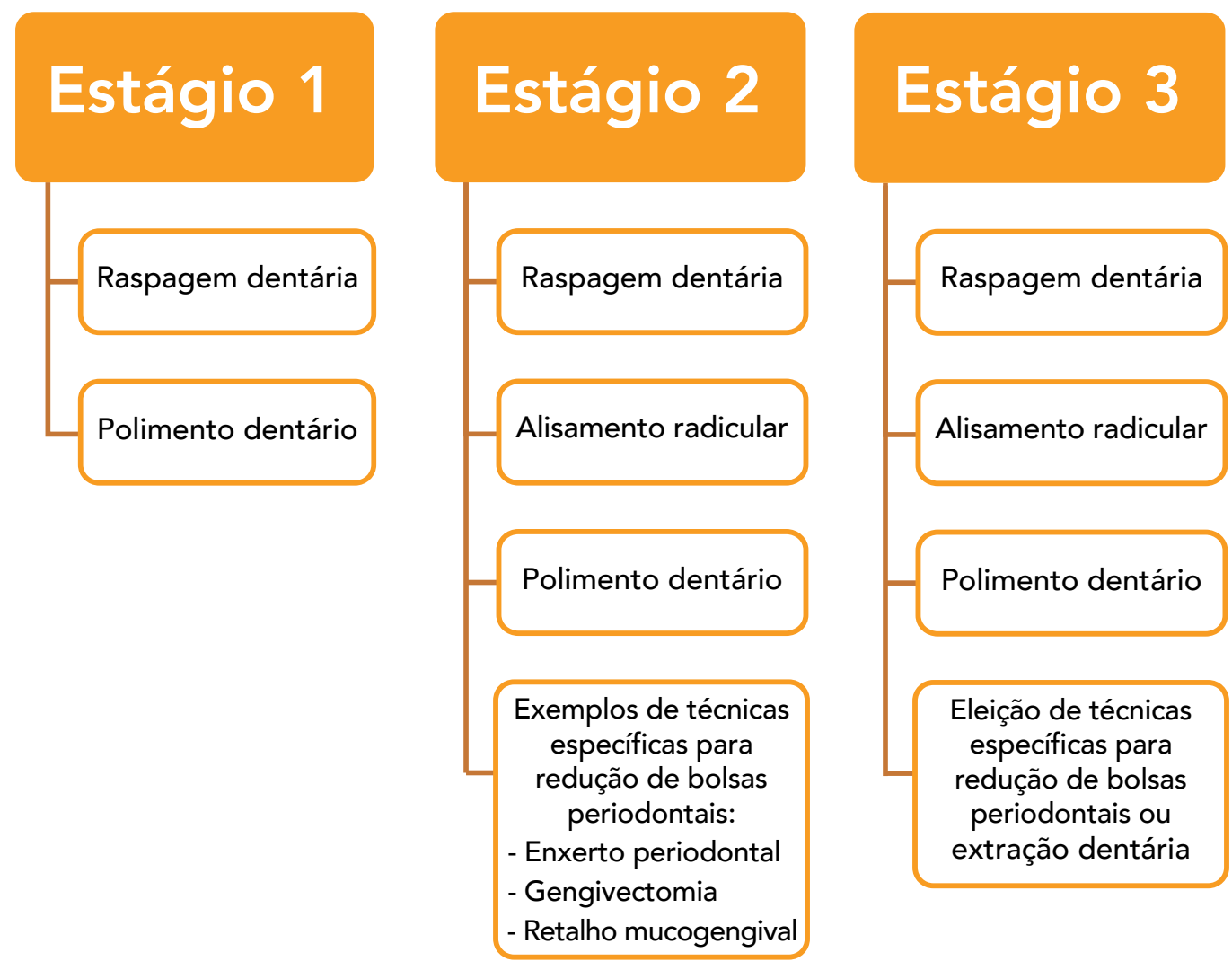

Estágio 4

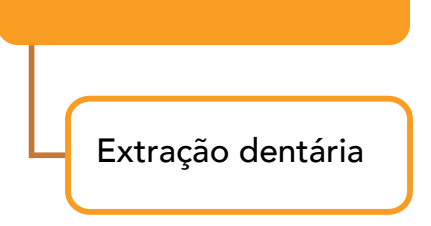




\section{ASPECTOS DO TRATAMENTO PERIODONTAL}

Utilização de sonda periodontal:
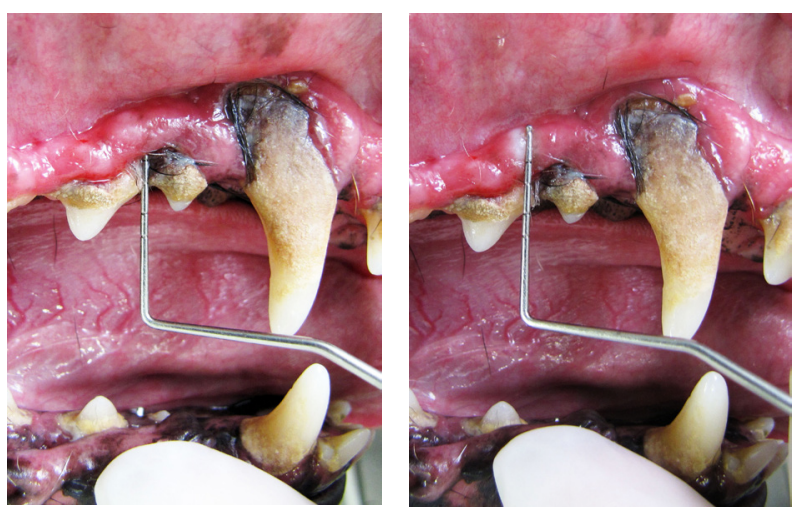

Utilização de ultrassom odontológico:

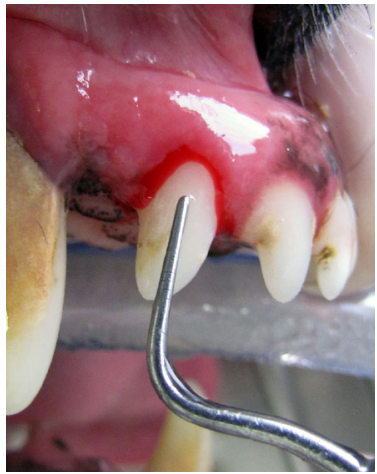

Nível supragengival

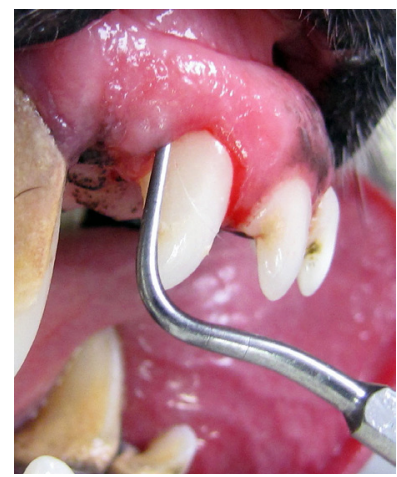

Nível subgengival

Utilização de curetas odontológicas:

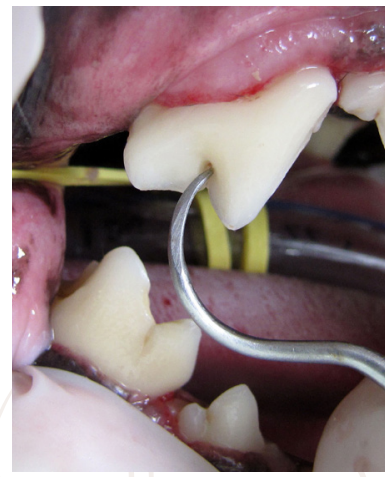

Nível supragengival

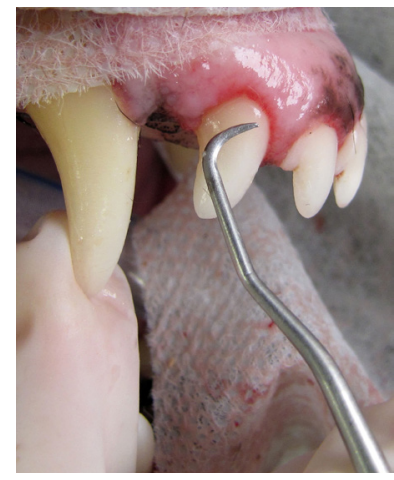

Nível supragengival

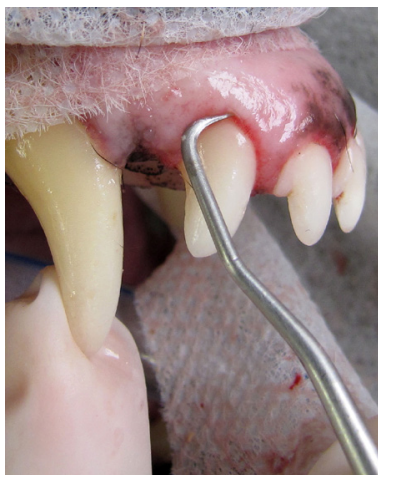

Nível subgengival

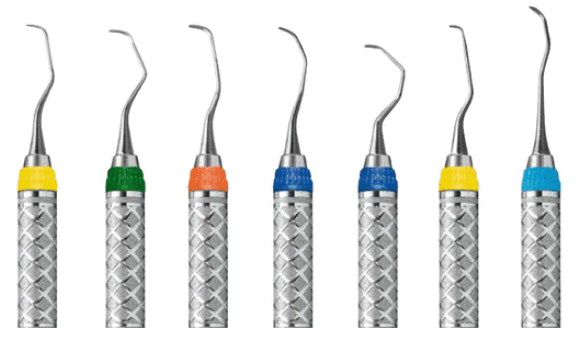

Curetas odontológicas

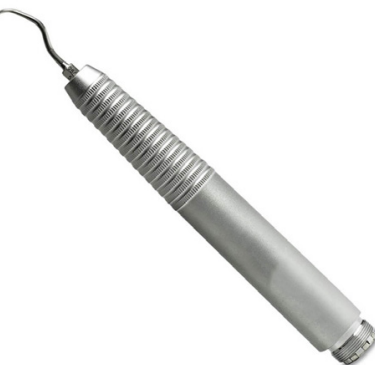




\section{Por que realizar radiografia intraoral de todos os dentes} em todos os pacientes submetidos ao tratamento periodontal?

A radiografia intraoral realizada em todos os dentes frequentemente revela afecções inesperadas que precisam de procedimentos cirúrgicos específicos. É imprescindível realizar este procedimento em todos os pacientes odontológicos, independentemente da queixa clínica apresentada.

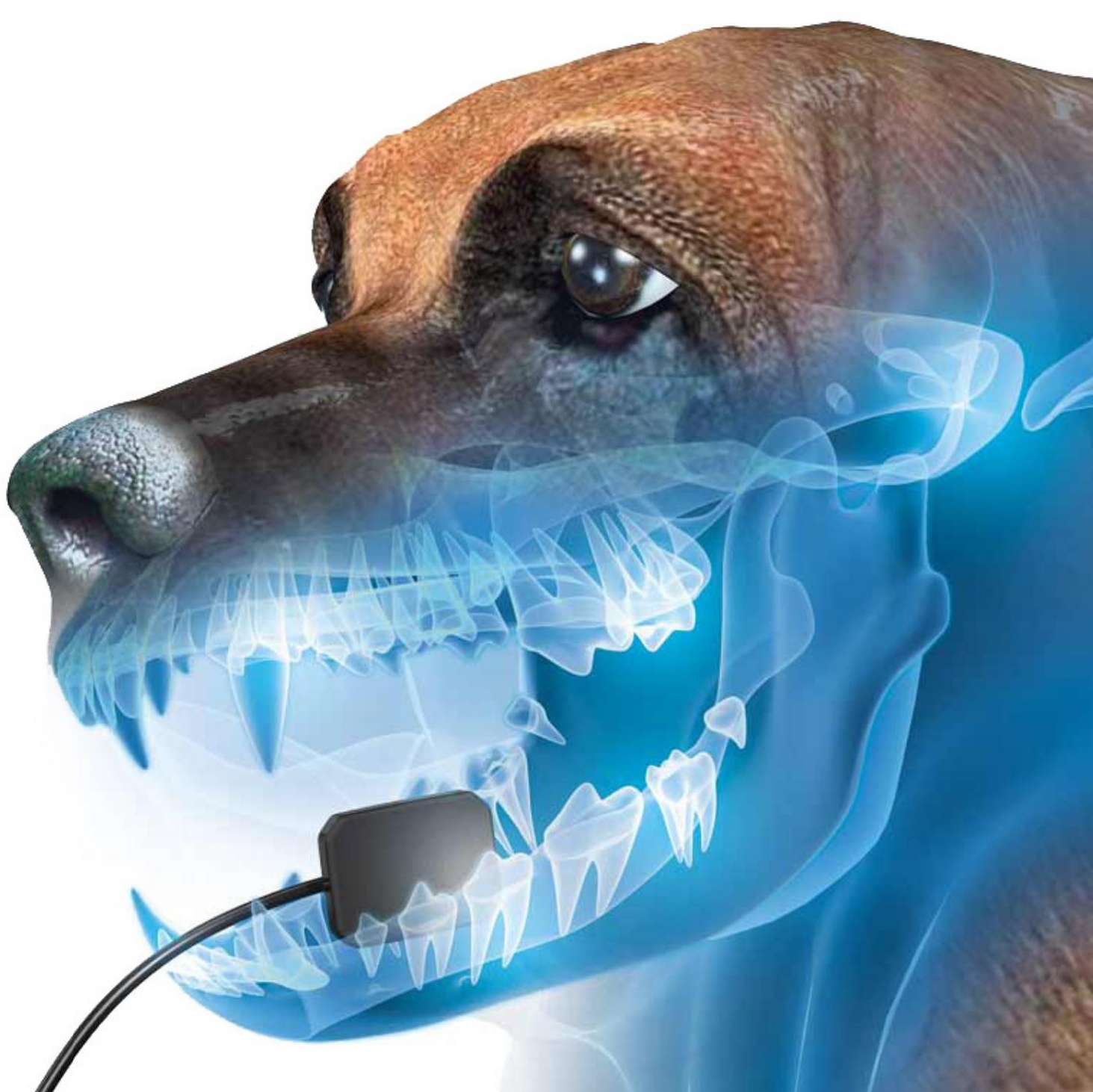




\section{ANTIBIOTICOTERAPIA PARA O TRATAMENTO PERIODONTAL}

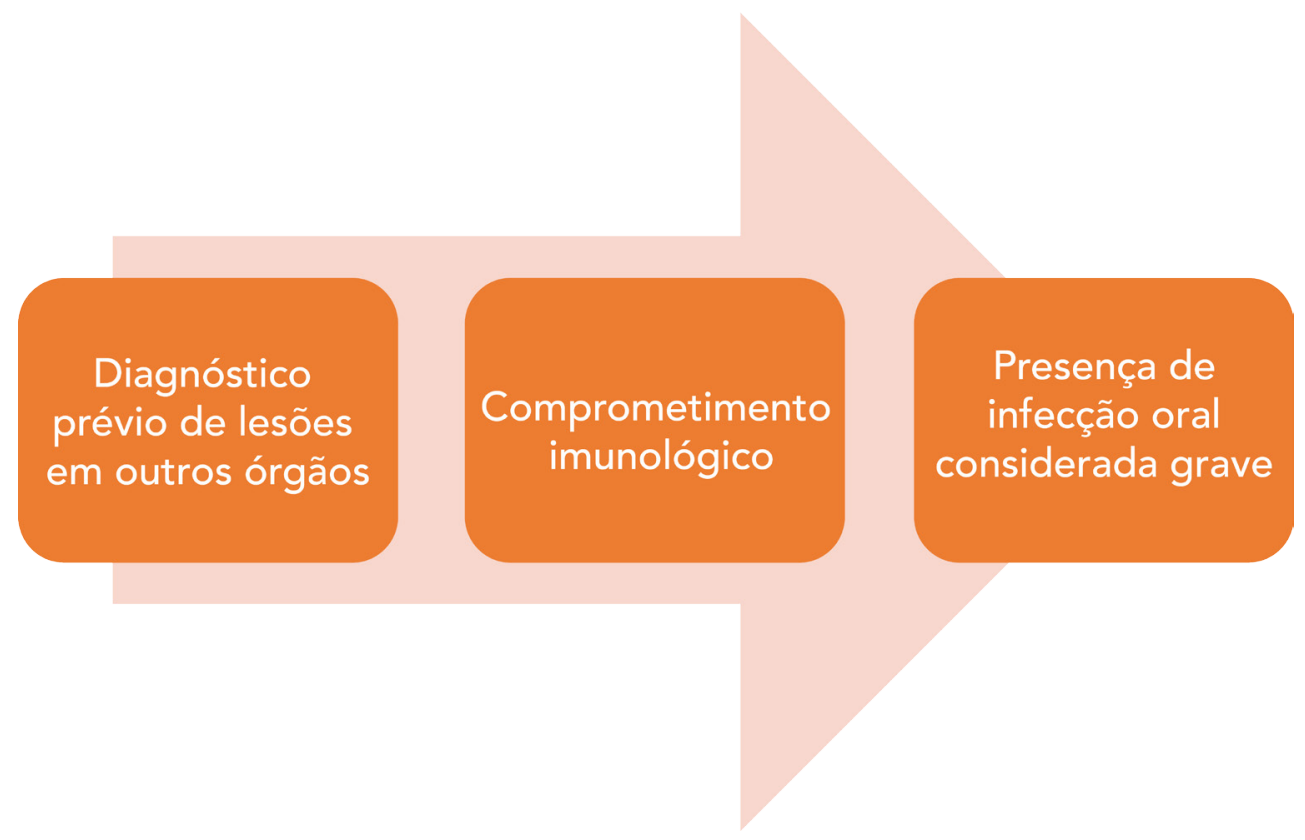

De acordo com o Colégio Americano de Odontologia Veterinária (AVDC), estas são as únicas situações em que se recomenda o uso de antibiótico sistêmico em pacientes submetidos ao tratamento periodontal. Antibióticos nunca devem ser utilizados como o único tratamento para a doença periodontal! 


\section{ANESTESIA PARA O TRATAMENTO PERIODONTAL}

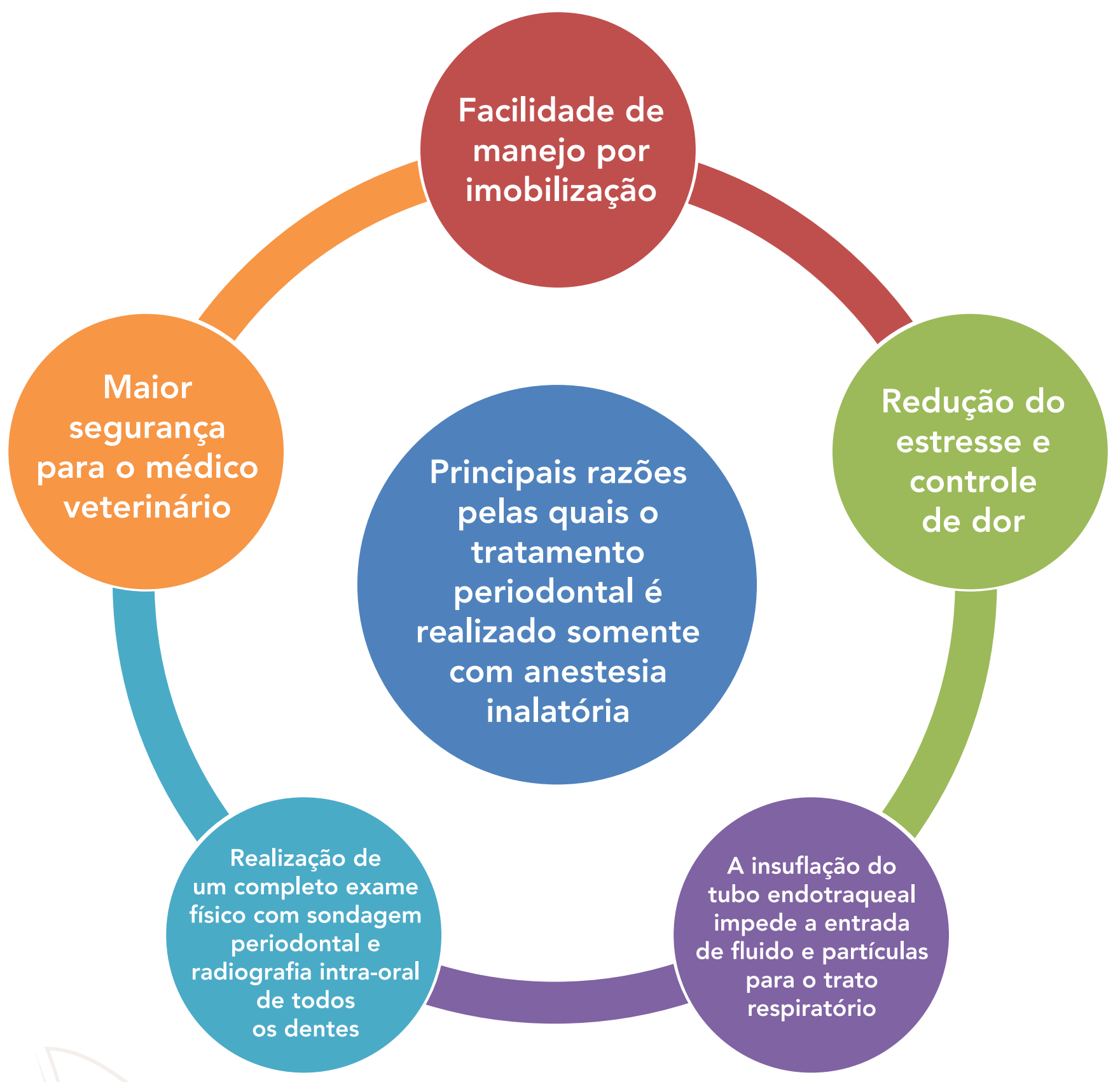




\section{ASPECTOS DA RESPONSABILIDADE CIVIL}

Na maioria das atividades profissionais pode haver a reparação do erro. Entretanto, na medicina veterinária, os erros normalmente não permitem o retorno ao estado anterior, podendo até levar ao óbito do paciente.

O erro médico define-se como uma forma inadequada de conduta profissional que, a partir de suposta inobservância técnica no exercício de sua profissão, produz dano à saúde do paciente. De acordo com o Código de Ética do Médico Veterinário, o profissional que pratica o erro médico deve ser responsabilizado civil e penalmente.

Negligência, imprudência e imperícia são três elementos jurídicos capazes de determinar uma responsabilidade por culpa e estão comumente presentes nas denúncias recebidas pelos Conselhos Regionais de Medicina Veterinária.

\section{Negligência}

Conduta dita como omissiva, descuidada, sem as devidas precauções necessárias

\section{Imprudência}

Falta de cautela, conduta precipitada que não dá importância às consequências

\section{Imperícia}

Incapacidade técnica para o exercício de determinada função 


\section{EXEMPLOS}

- Não realizar exames complementares prévios ao tratamento periodontal de um paciente;

- Ignorar a importância local e sistêmica da doença periodontal nos animais e não tratá-la.

\section{Negligência}

\section{Imperícia}

- Realizar extração dentária sem a realização prévia de radiografia intraoral;

- Causar lesões iatrogênicas por extração dentária, como por exemplo a persistência de fragmento radicular, lesão em gengiva, lesão ocular, laceração em tecido mole, fratura de mandíbula e maxila, inflamação alveolar, comunicação oronasal, dano ao dente hígido adjacente, rinite crônica, hemorragia, enfisema, edema sublingual, infecção local, infecção sistêmica, etc.

\section{Imprudência}


Mito 1: "É possível realizar o tratamento periodontal sem anestesia".

\section{Somente a anestesia geral inalatória é capaz de permitir uma intervenção odontológica comple-}

ta e segura. A total imobilização do paciente possibilita o acesso dos instrumentos odontológicos à região subgengival sem gerar danos teciduais. A insuflação do tubo endotraqueal impede a entrada de fluidos para o trato respiratório. Além disso, pode-se controlar adequadamente a dor e desconforto dos nossos pacientes durante o procedimento... Não é possível realizar um tratamento periodontal de qualidade sem anestesia!

Mito 2: "O tratamento periodontal é um procedimento simples e não precisa de muita atenção na anestesia"

O tratamento periodontal é um procedimento longo e complexo, pois cada dente deve ser individualmente avaliado e completamente tratado conforme sua necessidade. Assim sendo, para garantir a segurança do paciente tornam-se essenciais a monitoração e avaliação anestésica durante todo o procedimento. O profissional anestesista deve atentar-se para sinais clínicos como movimentos voluntários do paciente, reflexo palpebral, posicionamento de globo ocular, padrão respiratório e tônus mandibular. O eletrocardiograma deve ser realizado durante todo o procedimento anestésico por diversas razões como a hipotermia decorrente de procedimentos odontológicos, considerado um fator predisponente para alterações no ritmo cardíaco como bradicardia e até fibrilação ventricular em casos severos. A oximetria de pulso auxilia na mensuração do nível de saturação de oxigênio nas hemácias. É importante lembrar que, em procedimentos odontológicos, esta aferição não deve ser realizada na língua devido à manipulação da cavidade oral! Por sua vez, a análise capnográfica permite a avaliação da ventilação do paciente, auxiliando na identificação de problemas com a sonda endotraqueal, como extubação acidental e obstrução por sangue, secreções e sedimentos dentários. Caso seja necessária, esta análise torna-se parâmetro para a realização de ventilação assistida. De maneira geral, anestésicos inalatórios, somados à hipotermia, apresentam efeito hipotensor e, por esta razão, a pressão arterial também precisa ser constantemente monitorada. Sendo assim, não existe a possibilidade de realizar um procedimento odontológico seguro sem uma adequada monitoração anestésica! 
Mito 3: "Após a extração dentária, o local deve permanecer aberto para drenar e permitir uma cicatrização por segunda intenção".

$\mathrm{Na}$ verdade, após a extração dentária, a região alveolar deve ser cuidadosamente higienizada com curetas específicas para a remoção de tecidos de granulação, debris celulares, material purulento ou tecido ósseo necrosado e, em seguida, suturada. Suturar a região alveolar após a extração dentária acelera a recuperação tecidual, previne infecção e reduz a dor no período pós-operatório. A sutura deve ser realizada sem tensão para não haver deiscência de ferida, devendo ser feito, quando necessário, o descolamento da região gengival de interesse e sendo preferível o padrão simples interrompido. Além disso, a manutenção de um coágulo dentro do alvéolo garante a proteção da região! A ausência da sutura pode culminar na perda deste coágulo, inflamação e dor intensa na região.

Mito 4: "O dente $4^{\circ}$ pré-molar superior ("carniceiro") deve ser extraído sempre que houver edema ou fístula em região facial abaixo dos olhos".

Antes de pensar em extrair o dente, para garantir um correto diagnóstico faz-se necessário realizar sondagem periodontal e radiografia intraoral em toda a boca, pois às vezes quem está afetado é outro dente como, por exemplo, o $1^{\circ}$ molar ou $3^{\circ}$ pré-molar superior. Há casos em que, devido à extensão da raiz e tamanho do focinho, os animais apresentam abscesso ou fístula pelo acometimento do dente canino. Nem sempre a extração é a única opção terapêutica! Às vezes, é possível preservar o dente através de um correto tratamento endodôntico! Uma extração inadequada com a permanência de fragmento radicular, sialoadenites, ferida por mordida ou corpo estranho, fratura de maxila com sequestro ósseo, neoplasia nasal ou maxilar também devem ser considerados como diagnósticos diferenciais para a causa de edema, abscesso ou fístula nesta região. 
Mito 5: "Um dente fraturado não precisa ser tratado enquanto o paciente não apresenta desconforto ou sinal claro de infecção".

Mesmo sentindo, os animais nem sempre demonstram dor e desconforto por um dente fraturado. É errado manter este dente na cavidade oral do animal sem tratá-lo, pois ele pode originar um abscesso na região ao redor da raiz do dente acometido! Dentes fraturados devem ser endodonticamente tratados e, quando não for possível, devido ao tipo de fratura, este dente deve ser corretamente extraído.

Mito 6: "A doença periodontal é suficientemente tratada com a raspagem do cálculo presente na superfície dentária".

O cálculo dentário supragengival, também conhecido como tártaro, não é o único agente responsável pela doença periodontal. Preocupar-se apenas em removê-lo não contribui para saúde do nosso paciente, mas pelo contrário, compromete sua saúde sistêmica. O cálculo supragengival atua como um escudo protetor para as bactérias subgengivais que causam a doença, auxiliando em sua aderência e proteção enquanto o periodonto é agredido. Remover o cálculo dentário supragengival é importante, mas é apenas a primeira etapa de várias outras, como a raspagem subgengival. Isto significa que fazer apenas uma limpeza de tártaro ou tartarectomia em um animal com doença periodontal não é benéfico, pois a doença continua instalada e assim será potencializada, prejudicando a saúde oral e sistêmica do paciente.

Mito 7: "Não faz diferença identificar o estágio da doença periodontal em cada dente para poder realizar o tratamento periodontal".

Na verdade, como vimos anteriormente nesta cartilha, a doença periodontal apresenta quatro estágios e só é possível tratá-la corretamente após a sondagem periodontal e radiografia intraoral de todos os dentes. Assim, após avaliação física e radiográfica, será possível saber se algum dente deve ser extraído ou alguma técnica de preservação pode ser utilizada, para que a saúde oral e sistêmica do animal seja alcançada. 
Mito 8: "A radiografia intraoral não é necessária antes da extração de dentes que apresentam mobilidade".

Existem diversas causas de mobilidade dentária além da doença periodontal e por esta razão é fundamental que a radiografia intraoral seja realizada. Pode-se estar diante de um caso de neoplasia, trauma dentário, fratura alveolar, fratura radicular, fratura de mandíbula ou maxila, por exemplo. Sendo assim, radiografias intra-orais devem ser sempre realizadas antes da extração de dentes que apresentam mobilidade para garantir uma correta determinação da causa e determinar o tratamento adequado.

Mito 9: "Um paciente com abscesso periapical deve ser apenas tratado com antibióticos".

Um abscesso periapical é um processo inflamatório e infeccioso caracterizado pela formação de pus na região do ápice de um dente, normalmente decorrente de doença periodontal, trauma ou fratura dentária. Este material purulento gera dor e desconforto ao paciente e deve ser tratado cirurgicamente, a partir de tratamento endodôntico ou extração dentária. A simples administração de antibiótico sistêmico não é capaz de sanar a causa do problema.

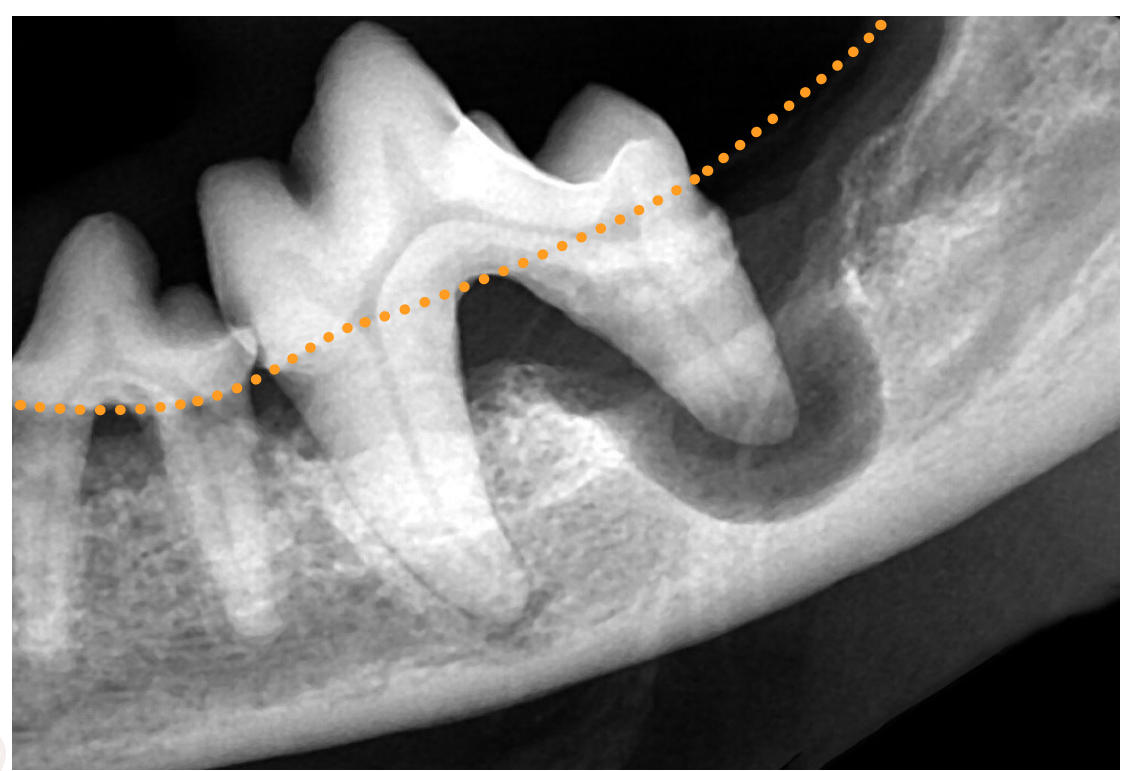

A linha pontilhada representa a altura óssea esperada de um dente hígido. 
Mito 10: "Todo paciente com doença periodontal precisa de antibiótico".

\section{Quando organizadas em forma de placa, as bactérias tornam-se quase mil vezes mais resis-}

tentes. Por isso, os antibióticos não são capazes de desorganizar a placa bacteriana subgengival e interromper a progressão da doença periodontal. Sendo assim, é fundamental que seja realizado um correto tratamento periodontal. Antibióticos devem ser utilizados apenas para casos em que o paciente apresente infecção oral severa, comprometimento imunológico prévio ou lesão instalada em outros órgãos. Nestes casos, utilizados apenas como terapia complementar ao tratamento periodontal, os antimicrobianos auxiliam no controle da bacteremia, reduzindo a anacorese.

Mito 11: "A odontologia é apenas um serviço acessório e estético oferecido na medicina veterinária".

Cuidar da boca do animal não é uma questão estética. A partir da leitura completa desta cartilha pode-se constatar a importância da preservação da saúde oral para a manutenção da saúde sistêmica dos nossos pacientes. É obrigação de todo médico veterinário atentar-se à cavidade oral do animal enquanto realiza seu exame físico, independentemente do motivo da visita deste paciente ao consultório e, sempre que identificada a doença periodontal, um correto tratamento deve ser planejado e executado. Manter a saúde oral dos animais previne e auxilia o tratamento de diversas doenças endócrinas, articulares, cardiovasculares, renais, respiratórias, etc.

Mito 12: "É melhor esperar acumular mais cálculo dentário para removê-lo".

Este talvez seja um dos maiores erros cometidos por médicos veterinários. A doença periodontal causa inflamação, infecção e destruição do tecido periodontal, além de severos danos sistêmicos já discutidos. Quanto mais tempo ela ficar instalada, maior é o dano por ela causado. 


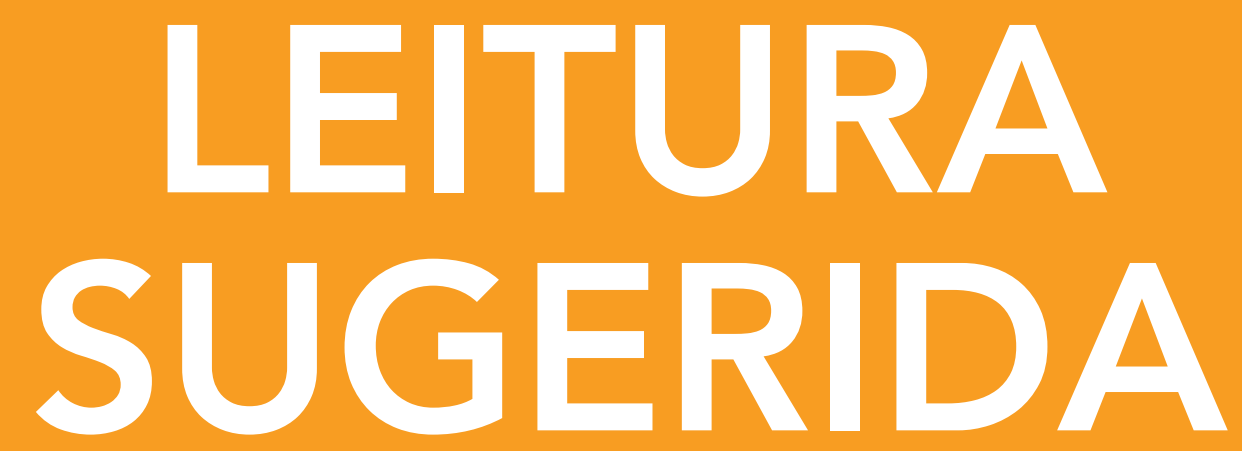

AMERICAN VETERINARY DENTAL COLLEGE (AVDC)

http://www.avdc.org

ASSOCIAÇÃO BRASILEIRA DE ODONTOLOGIA VETERINÁRIA (ABOV)

http://www.abov.org.br

GIOSO, M.A. Odontologia veterinária para o clínico de pequenos animais. 2. ed. São Paulo: Manole, 2007. 142p.

GORREL, C. Odontologia em pequenos animais. Rio de Janeiro: Elsevier, 2010. 240p.

HOLMSTROM, S.E. et al. 2013 AAHA dental care guidelines for dogs and cats. Journal of American Animal Hospital Association, v. 49, n. 2, p. 75-82, 2013.

LOBPRISE, H.B. Odontologia em pequenos animais: consulta em 5 minutos. São Paulo: Revinter, 2010. 408p.

TUTT, C. Small animal dentistry: a manual of techniques. Oxford: Blackwell, 2006. 282p.

WIGGS, R.B.; LOBPRISE, H.B. Veterinary dentistry: principles and practice. Philadelphia: Lippincott-Raven, 1997. 748p. 